\title{
Examining Open Source Telecommunications
}

\section{Companies}

\author{
by \\ Haijun (Peter) Liu
}

A thesis submitted to the Faculty of Graduate Studies and Research in partial fulfillment of the requirements for the degree of Master of Applied Science in Technology Innovation Management

\author{
Department of Systems and Computer Engineering \\ Carleton University \\ Ottawa, Canada K1S 5B6 \\ September 2007
}

(c) Copyright 2007 Haijun (Peter) Liu 


$\begin{array}{ll}\begin{array}{l}\text { Library and } \\ \text { Archives Canada }\end{array} & \begin{array}{l}\text { Bibliothèque et } \\ \text { Archives Canada }\end{array} \\ \begin{array}{l}\text { Published Heritage } \\ \text { Branch }\end{array} & \begin{array}{l}\text { Direction du } \\ \text { Patrimoine de l'édition }\end{array} \\ \begin{array}{l}\text { 395 Wellington Street } \\ \text { Ottawa ON K1A 0N4 }\end{array} & \begin{array}{l}\text { 395, rue Wellington } \\ \text { Ottawa ON K1A ON4 }\end{array} \\ \text { Canada } & \begin{array}{l}\text { Canada } \\ \end{array}\end{array}$

Yourfile Votre référence

ISBN: 978-0-494-36827-5

Our file Notre référence

ISBN: 978-0-494-36827-5

NOTICE:

The author has granted a nonexclusive license allowing Library and Archives Canada to reproduce, publish, archive, preserve, conserve, communicate to the public by telecommunication or on the Internet, loan, distribute and sell theses worldwide, for commercial or noncommercial purposes, in microform, paper, electronic and/or any other formats.

The author retains copyright ownership and moral rights in this thesis. Neither the thesis nor substantial extracts from it may be printed or otherwise reproduced without the author's permission.
AVIS:

L'auteur a accordé une licence non exclusive permettant à la Bibliothèque et Archives Canada de reproduire, publier, archiver, sauvegarder, conserver, transmettre au public par télécommunication ou par l'Internet, prêter, distribuer et vendre des thèses partout dans le monde, à des fins commerciales ou autres, sur support microforme, papier, électronique et/ou autres formats.

L'auteur conserve la propriété du droit d'auteur et des droits moraux qui protège cette thèse. $\mathrm{Ni}$ la thèse ni des extraits substantiels de celle-ci ne doivent être imprimés ou autrement reproduits sans son autorisation.
In compliance with the Canadian

Privacy Act some supporting forms may have been removed from this thesis.

While these forms may be included in the document page count, their removal does not represent any loss of content from the thesis.
Conformément à la loi canadienne sur la protection de la vie privée, quelques formulaires secondaires ont été enlevés de cette thèse.

Bien que ces formulaires aient inclus dans la pagination, il n'y aura aucun contenu manquant.

\section{Canadä}


The undersigned hereby recommend to the Faculty of Graduate Studies and Research acceptance of the thesis

\title{
Examining Open Source Telecommunications Companies
}

\author{
submitted by \\ Haijun (Peter) Liu
}

In partial fulfillment to the requirements for the degree of Master of Applied

Science in Technology Innovation Management

Victor Aitken, Department Chair

A.J. Bailetti, Thesis Supervisor

Carleton University

September 2007 


\section{ABSTRACT}

This exploratory research uses theory to asses the type of innovation that open source telecommunications companies represent. Research results suggest that open source telecommunications companies represent new disruptive innovation in the networking monitoring market, a low end market disruption in the IP telephony market, and that they are disruptive to the overall telecommunications market. Results also shed light on: (i) how open source telecommunications companies manage relationships with the open source projects upon which they depend, (ii) reasons for venture capital investment in open source telecommunications companies, (iii) ways open source telecommunications companies use open source software to make money, and (iv) benefits and risks associated with depending on OSS to generate revenue.

This research is relevant to top management teams of companies that sell proprietary products in the telecommunications access market because it describes the disruption which they now face, to academics because they can examine how theoretical perspectives were applied to make sense of a new phenomenon, to entrepreneurs because they can understand how open source telecommunications companies came to existence and make money in the telecommunications industry, and to market analysts because it provides facts about the telecommunications market that are not well known. 


\section{ACKNOWLEDGEMENTS}

I am deeply grateful to my thesis supervisor Professor Tony Bailetti for his dedication, his guidance, his thoroughness, and his insistence on quality. With his unimaginable energy, he guided this thesis research every step along the journey. I not only learned academically from Professor Bailetti, I also personally experienced the power of passion and dedication from Professor Bailetti.

I thank Professor John Callahan for the help on modularization. The author learned a lot from courses he taught, and the innovation theory paradigm is one example. The author is grateful to other TIM faculties who have provided feedbacks and recommendations on this thesis.

I am deeply thankful to my wife for her understanding and support. She has to take care of our two young children alone most of the time when I was busy with my study. To my son Jia Liu and my daughter Ying Liu, I want to say you are the most valuable treasure I have in the world. Thanks for the joy you've brought to me.

Finally I would like to say thank you to my manager Brian Kay, and my employer Dragonwave Inc. for the assistance and understanding I have received. 


\section{TABLE OF CONTENTS}

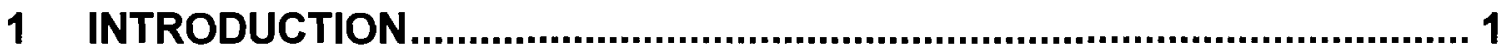

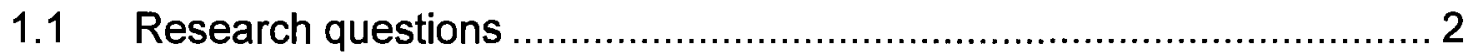

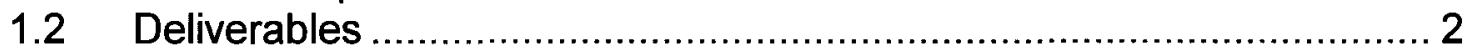

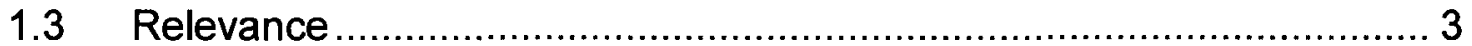

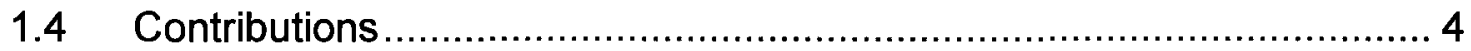

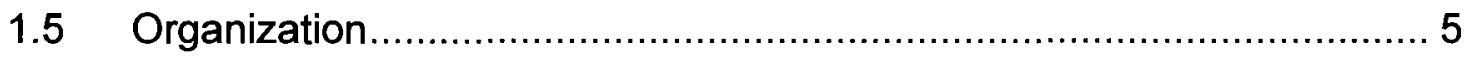

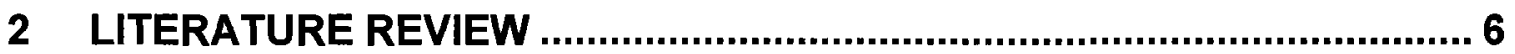

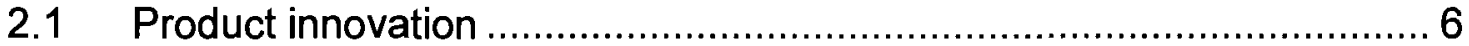

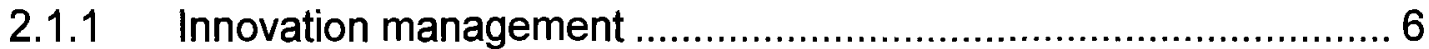

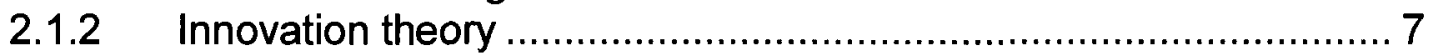

2.1.3 Technology life cycle........................................................... 11

2.1.4 Modularization and commoditization...................................... 12

2.2 Company interdependency ........................................................ 13

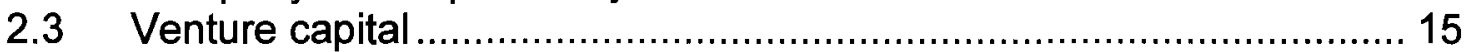

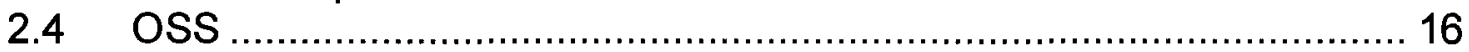

2.4.1 How is OSS used to make money .............................................. 16

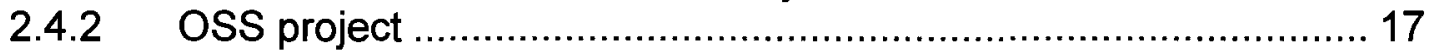

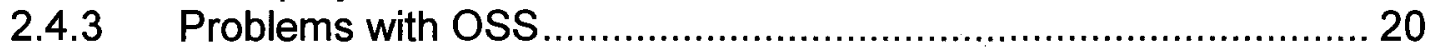

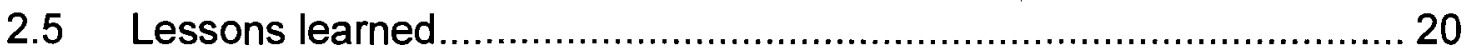

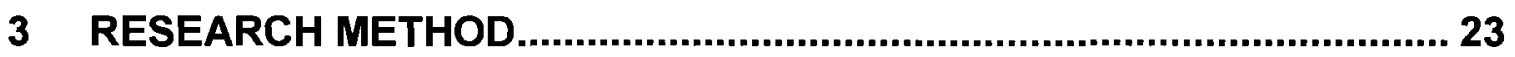

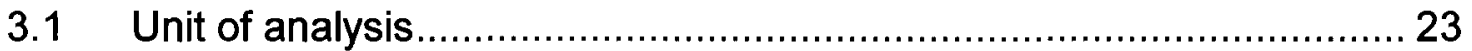

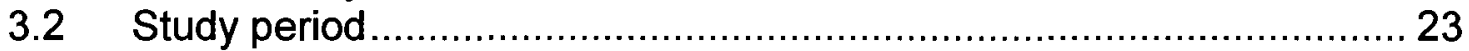

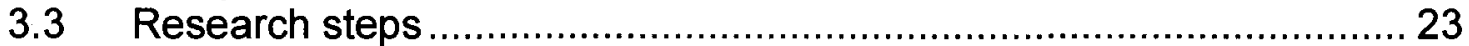

3.4 Identify research questions ....................................................... 25

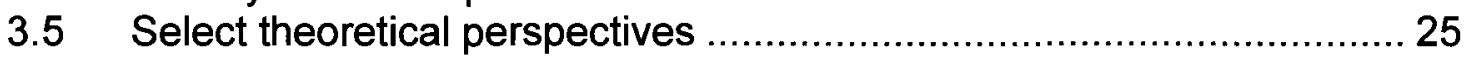

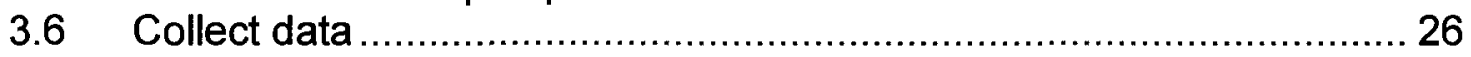

3.6.1 Determine criteria for sample selection .................................... 26

3.6.2 Find companies to be in the sample ......................................... 26

3.6.3 Collect data on each company ............................................. 28

3.6.4 Describe companies in the sample ........................................ 29

3.6.5 Identify OST companies' categories .......................................... 30

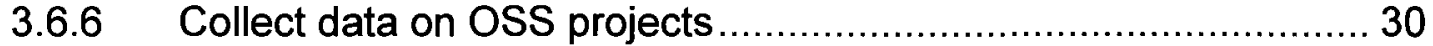

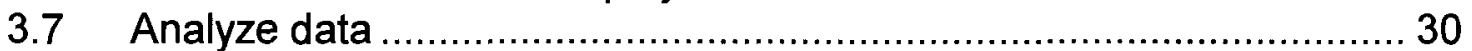

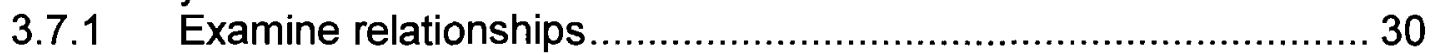

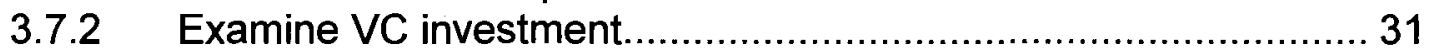

3.7.3 Identify ways OSS is used to make money................................ 31

3.7.4 Identify benefits and risks .................................................... 31

3.7.5 Identify communities anchored around OST companies............... 31

3.8 Asses the nature of disruptiveness using theory ............................. 32

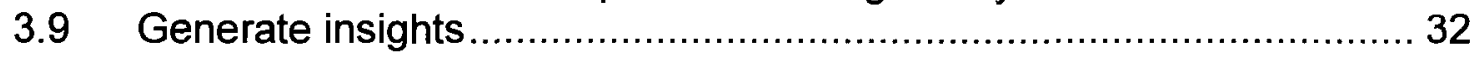

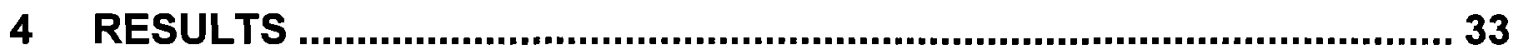




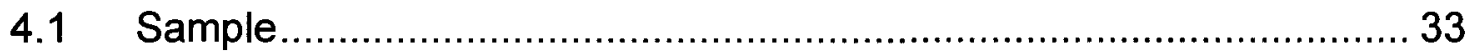

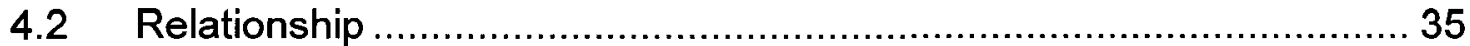

4.2.1 Relationship between commercial offering and OSS .................. 35

4.2.2 Relationship between an OST company and its corresponding OSS project 36

4.3 OST company and capital suppliers ….......................................... 37

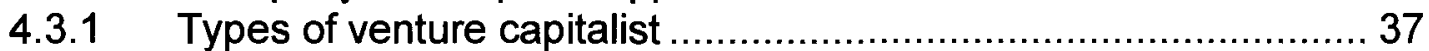

4.3.2 Reasons why OST companies seek VC investment................... 39

4.3.3 Reasons why VCs invest in OST companies............................ 40

4.4 Ways OST companies use OSS to make money ............................ 42

4.5 Benefits and risks OST companies have by depending on OSS ........ 44

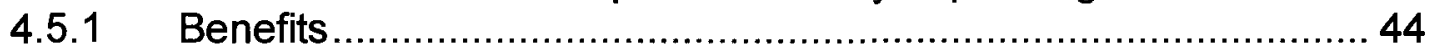

4.5.2 Risks OST companies may face ........................................... 45

4.6 Location of OST companies in the telecommunications industry ......... 46

4.6.1 Telecommunications OSS projects' location in the network.......... 46

4.6.2 Location of OST companies in the network .................................46 46

5 DISCUSSION OF RESULTS ................................................................ 48

5.1 Answers to research questions ................................................ 48

5.1.1 What type of innovations do OST companies represent? ............ 48

5.1.1.1 Litmus tests ............................................................... 48

5.1.1.2 Network monitoring market segment ............................... 49

5.1.1.3 IP telephony market segment ......................................... 52

5.1.1.4 OST is low-end disruptive innovation................................. 54

5.1.1.5 OST companies in the router market ..................................55

5.1.1.6 Modularization and OST ............................................... 56

5.1.2 Relationship management is key to OST companies ................. 58

5.1.3 VC investment in OST companies ........................................ 59

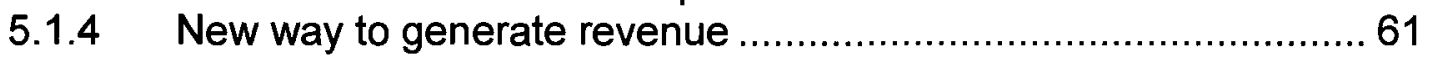

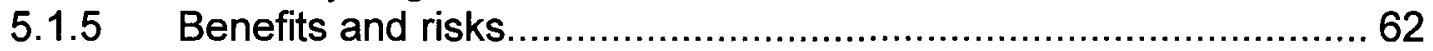

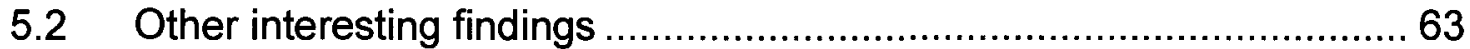

5.2.1 Communities anchored around competing OST companies......... 63

5.2.1.1 OSS projects in IP telephony ..............................................63

5.2.1.2 OSS projects compete with each other................................65

5.2.1.3 Two competing OST IP telephony company communities..... 66

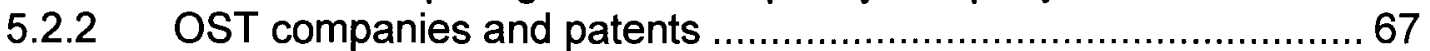

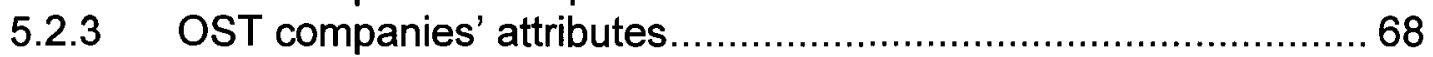

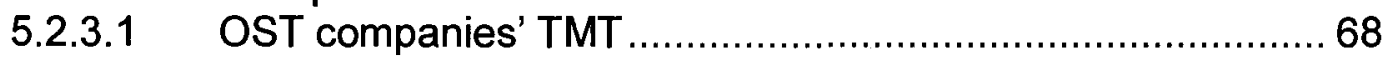

5.2.3.2 OSS creator is a special asset to an OST company.............69

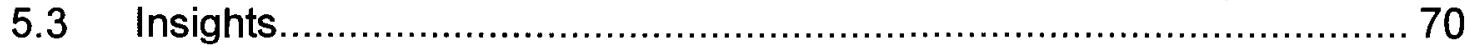

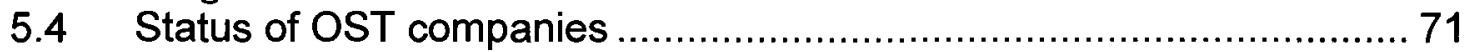

\section{CONCLUSIONS, LIMITATIONS AND SUGGESTIONS FOR FUTURE}

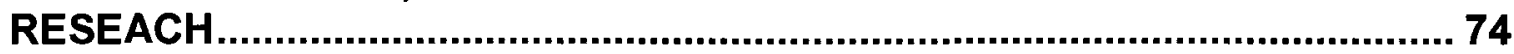

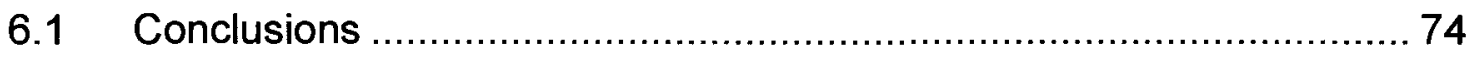

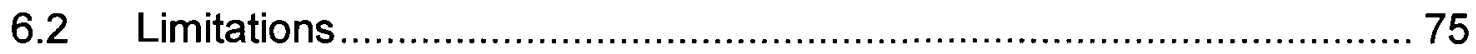

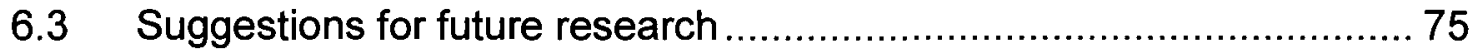




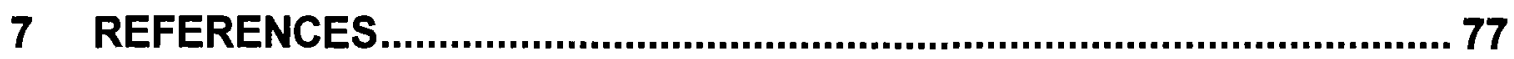




\section{LIST OF FIGURES}

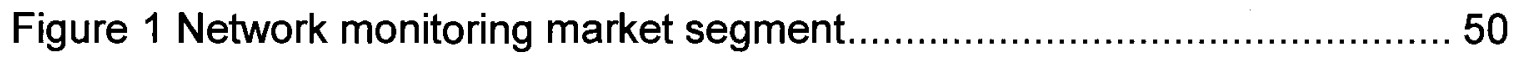

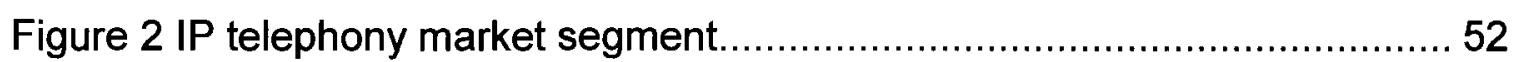

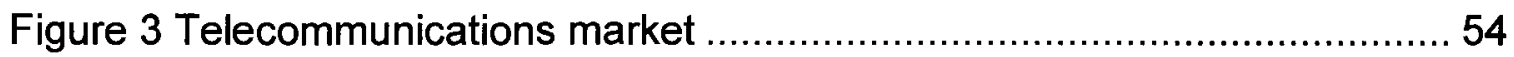

Figure 4 Open source IP telephony companies ........................................... 67 


\section{LIST OF TABLES}

Table 1 Strategies that companies use to make money from OSS identified by

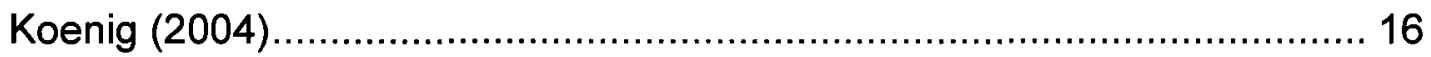

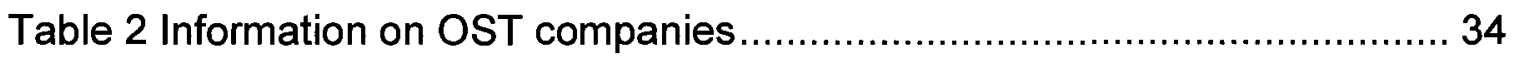

Table 3 Relationship between commercial offer and OSS .............................. 35

Table 4 Relationship between an OST company and OSS project ................... 37

Table 5 Types of VC organizations that invested in OST companies................ 38

Table 6 Reasons why OST companies seek VC investment ............................. 39

Table 7 Reasons why VCs invest in OST companies ......................................40

Table 8 Ways an OST company uses OSS to make money ............................ 42

Table 9 Benefits OST companies may accrue ................................................ 44

Table 10 Risks an OST company may face .................................................. 45

Table 11 Telecommunications OSS projects in the network ........................... 46

Table 12 OST companies in the network ................................................. 47

Table 13 Comparison between how OSS and OST companies make money ... 61

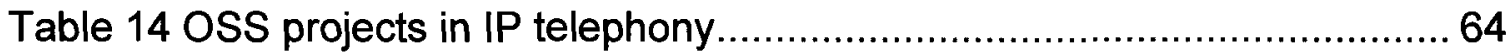

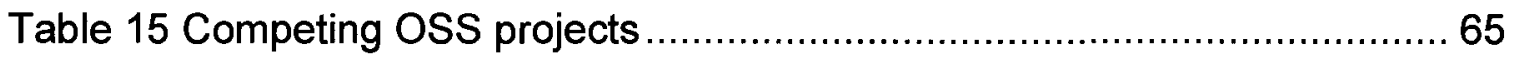

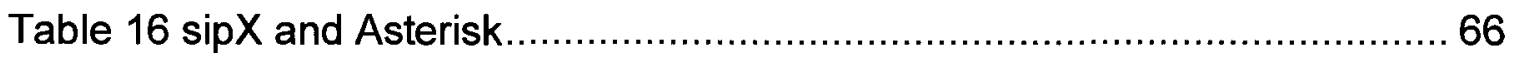

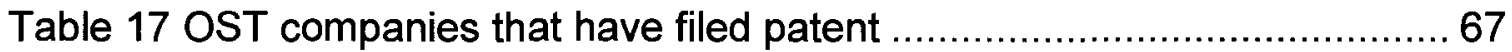

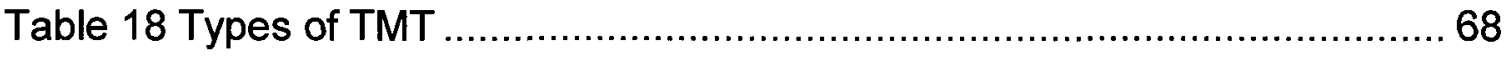

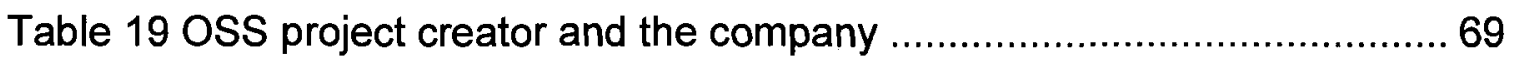




\section{INTRODUCTION}

Much has been published in the last several years about companies whose core business is to sell software products that rely on open source projects (Koenig, 2004; Bonaccorsi and Rossi, 2004; Bonaccorsi, et al., 2004; Rossi and Bonaccorsi, 2005; Yang, 2006). Many open source companies such as Red Hat ${ }^{1}$, JBOSS $^{2}$, Sleepycat, MySQL AB, Compiere, Alfresco, Funambol, Pentaho, SourceLabs, Gluecode, and SugarCRM are successful in various software product markets ${ }^{3}$, and Linux has spread to more than $25 \%$ of the world's servers ${ }^{4}$.

For the purpose of this research, an open source telecommunications (OST) company is a company whose core business is to sell telecommunications products that lever open source projects. An OST company can not exist if not for the open source software (OSS) project upon which its market offers depend.

Little is known about OST companies. OST companies are different from other OSS companies. The telecommunications market is different from the software product market. The telecommunications market is highly regulated, vertically integrated, and proprietary designs and special chips are widely used ${ }^{5}$. For a

\footnotetext{
${ }^{1}$ Founded in 1993, specializes in Linux software distribution and services. Listed at NYSE RHT, with a market cap of $\$ 4.36 \mathrm{~B}$.

${ }^{2}$ Founded in 1999, a middleware company was bought by Red Hat with $\$ 400 \mathrm{~m}+$ in April 2006.

${ }^{3} \mathrm{http} / / \mathrm{www}$. cio.com/archive/021506/opensource.html?page $=2$

$4 \mathrm{http} / / / \mathrm{www}$. businessweek.com/magazine/content/06 11/b3975100.htm

5 http://www.tmcnet.com/channels/voip-developer/articles/165-voice-ip-open-source-the-traditionalbusiness-model.htm
} 
telecommunications product to be useful, it has to interact with access network products and core network products. Due to specifications in Service Levels Agreements ${ }^{6}$, penalties for failures of telecommunications products are very high.

\subsection{Research questions}

This research uses theory and publicly available information to answer the following five questions:

1. What type of innovations do OST companies represent?

2. What type of relationships do commercial offerings of OST companies have with the open source projects upon which they depend and what type of relationships do OST companies have with the OSS projects upon which they depend?

3. What are the reasons that venture capital firms invest in OST companies and what are the reasons that OST companies search for venture capital?

4. How do OST companies use OSS to make money?

5. What are the benefits and risks of OST companies that depend on OSS for their revenue?

\subsection{Deliverables}

This research delivers:

1. Answers to the five research questions

2. A list of insights

\footnotetext{
${ }^{6} \mathrm{http}: / /$ www.networkworld.com/columnists/2002/0325eye.html
} 
3. Description of interesting findings outside of the answers to research questions

4. A database that includes information on OST companies, including a description of how they came to be and the role of open source projects in supporting companies' inception and growth

\subsection{Relevance}

This research is relevant to top management teams of companies that sell proprietary network access products, entrepreneurs, academics, and market analysts.

Top management teams of companies that sell proprietary network access products will find the assessment of the nature of the disruption they now face interesting. Researchers have examined how to respond to these disruptive innovations. Managers have much to gain by better understanding the nature of the disruptions that affect them and how to respond to them.

Entrepreneurs will be interested in learning about the different ways OST companies came into existence, make money, lever open source projects, and the reasons why venture capitalists (VCs) invest in OST companies.

Academics will be interested in how disruptive and modularization theories were applied to make sense of a new phenomenon, OST companies. Moreover, the 
database of OST companies will be of interest to researchers who study open source businesses.

Market analysts will be interested in obtaining information that is not well known, for example a list and types of VC firms that invested in OST companies, and in which market segments OST companies are gaining market momentum.

\subsection{Contributions}

This research makes at least four contributions:

- Provides evidence that OST companies (i) are addressing the needs of two access markets: IP telephony and network monitoring, and (ii) have started to move into the core network with the introduction of a wide area router

- Concluded that OST companies represent (i) a new market disruptive innovation for the network monitoring market, (ii) a low-end disruptive innovation for the IP telephony market, and (iii) a low-end disruptive innovation to the traditional telecommunications industry

- Identified that selling proprietary hardware that is complementary to OSS is one way that OST companies use to generate revenue that OSS product companies do not

- Identified two OST company communities that compete with one another. These two communities are: the sipX company community anchored 
around Pingtel and the Asterisk company community anchored around Digium. They compete in the same IP telephony market segment

\subsection{Organization}

The thesis is organized into six chapters. Chapter 1 is the introduction. Chapter 2 reviews the literature. Chapter 3 describes the research method. Chapter 4 describes the results. Chapter 5 discusses the results. Chapter 6 provides the conclusions, discusses the limitations of this research, and identifies opportunities for future research. 


\section{LITERATURE REVIEW}

This chapter reviews the literature. Section 2.1 reviews product innovation, including modularization and commoditization. Section 2.2 reviews company interdependencies. Section 2.3 reviews venture capital investment. Section 2.4 reviews the OSS literature. Finally, section 2.5 provides the lessons learned from the literature review.

\subsection{Product innovation}

Researchers have long been puzzled about why great companies subsequently failed. They found innovation was the root cause for new entrants to succeed, and where great incumbent player stumbled. Researchers from Foster (1986) to Tushman (1986) to Henderson $(1990)$ to Christensen $(2003,2004)$ have made contributions to help a better understanding of what innovation is all about. Innovation theory has evolved from the descriptive stage to the normative stage, and researchers have proposed methods to identify disruptive innovations and strategies to deal with disruptive innovations.

\subsubsection{Innovation management}

Innovation is defined by Van de Ven (1986) as the development and implementation of new ideas by people who over time engage in transactions with others within an institutional context. Four fundamental problems need to be managed: the human problem of managing attention, the process problem of ideas into good currency, the structural problem of managing part-whole 
relationships, and the strategic problem of institutional leadership. New product development is an important way to embody product innovation. Brown and Eisenhardt (1995) provide an excellent review of the product development literature before 1995.

\subsubsection{Innovation theory}

Christensen (2003) argues that a good theory is a theory that people can use to predict outcomes based on circumstances. Attribute-based theory is the early stage of the theory building process. This phase is called the descriptive theory stage. For a theory to be applicable, it needs to become a normative theory (Christensen, 2006). From Foster (1986) to Christensen $(2003,2004)$, product innovation theory has moved from being attribute-based to being circumstancebased. Researchers have made various contributions to identifying how to handle these innovations (Gilbert and Bower, 2002).

Foster (1986) uses the concept of an S-curve to describe technology development progress. At the beginning of a new technology, the progress is limited even with significant amounts of investment, and the same is true when the technology has reached its threshold. There is a discontinuity when the old technology is replaced by the new one. It is the discontinuity that provides advantages to the attacker relative to the incumbent. Foster (1986) argues that discontinuity management is important to a company's fate, although it is extremely difficult to carry out. 
Tushman and Anderson (1986) observed that technology evolves through periods of incremental change punctuated by technological breakthroughs that either enhance or destroy the competence of firms in an industry. They argued that competence-destroying innovations are initiated by new entrants, and competence-enhancing innovations are initiated by incumbent players. The third important observation was that competence-destroying innovation will increase environmental turbulence, while competence-enhancing innovation tends to decrease environmental turbulence.

Building on Tushman and Anderson (1986), Henderson and Clark (1990) argue that categorizing innovations into either incremental or radical is incomplete. They categorized innovation into: incremental innovation, modular innovation, architectural innovation, and radical innovation. Radical innovation establishes a new dominant design (Utterback, 1996). Architectural innovation is very subtle. It may entail a minor change in the relationship among the core components. However, architectural innovation destroys the usefulness of an existing company's architecture, although the components of the system remain unchanged.

Utterback (1996) studied innovation using the manufacturing industry as a unit of analysis, and found that a "dominant design" phenomenon exists. A dominant design is not necessarily technically superior to other alternatives. Nor does it 
necessarily meet the needs of a particular class of users. The dominant design embodies the requirements of the majority of customers, and it is a satisfier of many in terms of the interplay of technical possibilities and market choices. The emergence of a dominant design is a result of a collateral asset, industry regulation and government intervention, strategic maneuvering by individual firms, and communication between producers and users. Utterback (1996) highlighted that a product dominant design is much more significant than technical competition and progress.

Christensen (2003) argues that previous innovation theories described the characteristics of innovation, and that they can not be used to predict innovation. Based on his study of the disk drive industry, he proposed what is known as disruptive innovation theory. Christensen (2003) argues that there are two types of innovation: sustaining innovation and disruptive innovation. Few technologies or product ideas are inherently sustaining or disruptive. Disruptive innovation consists of two types: low-end market disruptive innovation and new market disruptive innovation. Three litmus tests were proposed to identify disruptive innovations. Test 1 determines if an innovation can be shaped into new-market disruptive innovation by examining if un-consumers can become consumers. If it fails test1, test2 decides if it can be shaped into a low-end disruptive innovation by examining if a valid business model exists to provide good-enough, but considerably cheaper products. If an innovation passes test 1 or test2, it still has 
to pass test 3 to be identified as disruptive innovation. Test 3 demands that for an innovation to be disruptive, it has to be disruptive to all existing players.

Strategy is becoming the art of managing assets that one does not own (lansiti, 2004). A company's strategy comes to life in two different ways: emergent and deliberate (Christensen, 2003). Deliberate strategy formulation is a top-down process, and it conscious and analytical. For it to be successful, it needs to encompass and address correctly the important details, make sense to all employees, and its execution is shielded from outside world's interferences. The process entails making assumptions about the future, defining a strategy, making investment decisions, and implementing the strategy. The emergent strategy formulation is a bottom-up process, and it is discovery-driven. The process entails making projections, identifying assumptions to achieve projected targets, implementing a plan to make assumptions, and making investment decisions once the assumptions are tested.

Gilbert and Bower (2002) use Christensen's theory (2003) to argue that it is not enough to identify the disruptive innovation. They argue that it is more important to learn how to manage it. Industry outsiders quite often win the battle over new disruptive innovations. They argue that during the resource allocation stage, the innovation is deemed a threat and treated as an opportunity during the execution stage. Specific recommendations include: separate for better performance, fund 
in stages, cultivate outside perspective, modularize integration, and consider acquisition.

\subsubsection{Technology life cycle}

A technology or product goes through several different stages from idea inception to end of life. Different stages of a product technology life cycle demand different types of innovation. Innovation needs to be aligned with the technology life cycle.

Utterback (1996) studied innovation at the industry level. He discovered that an industry goes through three phases: fluid, transition, and specific. The fluid phase is the pre-dominant design stage. No dominant design has emerged, so this stage features a greater number of product innovations. The source of innovation is mainly industry pioneers and users, and the basis of competition is functional product performance. Once a dominant design emerges, the industry enters the transitional stage. At this stage a greater number of process innovations than product innovations occur. The source of innovation is manufacturers and users, and vendors compete on product variation and fitness for use. The specific stage is a commodity stage. In this stage the innovations mostly come from suppliers, and they compete on price.

The technology life cycle has several stages: early market, the chasm, bowling alley, tornado, main street, fault line, and end of life (Moore, 2002, 2004). 
Different stages require different types of innovation. Before the chasm, disruptive innovations are needed. Once the technology crosses the chasm, the application innovations are needed for the bowling alley stage, and product innovations for the tornado stage. The main street stage has three sub-stages: early main stage, mature stage, and late main stage. The early main stage requires process innovation, the mature stage requires experiential and marketing innovation, and the late main street requires business model innovation. Structural innovation is needed when the technology enters its last phase of life.

\subsubsection{Modularization and commoditization}

Integrated architecture leads to healthy profits, and modularization leads to commoditization (Christensen, 2003). When a part of the system is not good enough, a company can use an integrated proprietary approach to provide better performance. Once the performance overshoots the requirements, the interface will modularize and healthy profits will disappear. A company's core competence is not about what it can do best; it is about what will be modularized and commoditized. When one part of the system starts to commoditize, typically another part of the system starts to de-commoditize. The law of conservation of attractive profits states that when modularity and commoditization causes attractive profits to disappear at one stage in the value chain, the opportunity to earn attractive profits with proprietary products will usually emerge at an adjacent stage. 
For an interface to be truly modular, it has to meet three requirements: specificability, verifiability, and predictability (Christensen, 2003). The customer and supplier both have to be able to clearly specify the interface, be able to measure and verify it, and the predictability will enable their individual designs to separate from each other.

\subsection{Company interdependency}

Today, the business network is like an organic ecosystem, and the crucial battle is not between individual firms but between networks of firms. In the network, companies occupy three roles: keystone, dominator, and niche player.

Companies in the keystone and dominator roles occupy the hub locations of their network. The keystone organization occupies a small part of the network, and it creates and shares value with the network by leveraging its hub location. The dominator occupies a very large portion of its network, and it fails to encourage diversity. Niche players are in the majority of a business network. Collectively they create and capture much of the value in a healthy network (lansiti, 2004).

Watson, et al. (2005) examined JBoss's growth through ecosystem cultivation. The company has developed a healthy ecosystem around itself, and the ecosystem is a part of the larger Java ecosystem created by Sun Microsystems.

The platform leadership framework uses the result of Gawer's Ph.D. thesis (2002). She examined Intel and argued that as a platform leader, a company 
needs to take the entire industry's health into consideration. Her framework consists of four constructs: scope of the firm, product technology (architecture, interfaces, and intellectual property), relationships with external complementors, and internal organization. Using a peripheral component interconnect $(\mathrm{PCl})$ bus architecture design, Intel successfully became a PC industry platform leader. Then Intel set up the Intel architecture lab (IAL) to take care of the health of the PC industry. Intel doesn't necessarily benefit from IAL directly. Instead, Intel uses IAL to cultivate a healthy environment in which it grows. Intel routinely gives away software to accelerate hardware adoption. IAL uses an open interface as well as a closed implementation strategy which protects these areas in which other Intel divisions compete.

Because of equilibrium, the market resists changes (Chakravorti, 2003). In the networked world, product performance alone won't make a vendor successful. Network effects are more important than individual product performance. A tipping point phenomenon exists in the network market. Once the market passes the tipping point, the network effect will take effect, and the market will expand like wild fire. There is a similarity between Moore's $(2002,2004)$ chasm and tornado concept and Chakravorti's (2003) network equilibrium and tip point concept.

Interconnections introduce inefficiencies. These are caused by fragmented and privately motivated form of decision making. For an innovation to be successful, 
Chakravorti (2003) argues that an innovator needs to establish a new status quo, not just break an existing status quo. To create a new status quo, an innovator needs to envision an end game, align with network hubs, and remain flexible as late as possible.

\subsection{Venture capital}

The first venture capital firm was established in 1946. A venture capital cycle starts with raising a venture fund, proceeds to invest in and monitor a firm, then exits the firm and returns capital back to investors (Gompers and Lerner, 2001; Zider, 1998). There are two types of venture capital: conventional venture capital and corporate venture capital (Rind, 1981). Compared with VCs, Corporate Venture Capitals (CVC) organizations are weaker in incentive intensity and financial discipline. They are more constrained in discovering alternative business models as well. But CVCs can potentially have a longer time horizon, larger investment, and extensive coordination of complementarities (Chesbrough, 2000). Chesbrough (2002) argued that compared with conventional VCs, CVCs did poorly. He proposed two dimensions to study CVCs: objective and linkage. Along those two dimensions (strategic versus financial, loose versus tight linkage), CVC investment can be classified into four types: driving investment (Microsoft made significant investment in support of its .net strategy), enabling investments (Intel's investments fall into this category), emergent investment (Lucent's investments fall into this category), and passive investment. There are 
three types of emergent investment: experimenting with new capabilities, developing a backup technology, and exploring strategic white space.

Although VCs invest in entrepreneurs' ventures, their relationship is not always a cooperative one. Cable and Shane (1997) argued that the relationship between VCs and entrepreneurs is similar to a prisoner's dilemma situation. Comparing VC-backed startups with non-VC-backed startups, Hellmann and Puri (2002) found that VCs play a larger role than money and monitoring. They found that VC-backed firms tend to replace founders with CEOs from the outside earlier than non-VC-backed firms.

\subsection{OSS}

\subsubsection{How is OSS used to make money}

Many researchers have examined how companies use OSS to make money (Koenig, 2004; Bonaccorsi and Rossi, 2004; Bonaccorsi, et al., 2004). Koenig (2004) identified seven strategies that companies use to generate revenue from OSS. Table 1 identifies these strategies and provides a short description for each one.

Table 1 Strategies that companies use to make money from OSS identified by Koenig (2004)

\begin{tabular}{|l|l|}
\hline Strategy & Description \\
\hline Optimization strategy & $\begin{array}{l}\text { The commodity layer of Linux enables the adjacent } \\
\text { layers of software to be optimized. } \\
\text { Oracle's Real Application Cluster is an example }\end{array}$ \\
\hline
\end{tabular}




\begin{tabular}{|l|l|}
\hline Dual license strategy & $\begin{array}{l}\text { The GPL license allows a customer to try out } \\
\text { software before committing to it, and the commercial } \\
\text { license gives customer an option to avoid putting } \\
\text { proprietary code back } \\
\text { MySQL and Sleepcat have dual licenses. }\end{array}$ \\
\hline Consulting strategy & $\begin{array}{l}\text { Professional consulting services for OSS are } \\
\text { provided. } \\
10 X \text { Software is an example. }\end{array}$ \\
\hline Subscription strategy & $\begin{array}{l}\text { Maintenance and updates are provided. } \\
\text { Red Hat is an example. }\end{array}$ \\
\hline Patronage strategy & $\begin{array}{l}\text { Eliminate competitor's leadership position. } \\
\text { IBM prevented Microsoft from monopolizing the web } \\
\text { server market. }\end{array}$ \\
\hline Hosted strategy & $\begin{array}{l}\text { Companies use OSS for its own infrastructure, but } \\
\text { don't sell it. } \\
\text { Google and Amazon are examples. }\end{array}$ \\
\hline Embedded strategy & $\begin{array}{l}\text { Half of the embedded systems market uses Linux. } \\
\text { Neoteris was a successful case. }\end{array}$ \\
\hline
\end{tabular}

\subsubsection{OSS project}

OSS is not about source code, it's about free distribution ${ }^{7}$.

The license shall not restrict any party from selling or giving away the software as a component of an aggregate software distribution containing programs from several different sources. The license shall not require a royalty or other fee for such sale.

OSS has been conceptualized as the result of an effort of a community of developers. The process used to develop OSS is very different from the process

\footnotetext{
${ }^{7}$ http://www.opensource.org/docs/definition.php
} 
used to develop proprietary software. The Internet and the bazaar development modes enable a successful OSS project to have coordination world-wide (Raymond, 1998; Bonaccorsi and Rossi, 2003; Lin, 2005; Rullani, 2006; Dahlander and Magnusson, 2005). After studying OSS projects from sourceforge.net, researchers found that the majority of OSS projects are developed by a small number of developers (Krishnamurthy, 2002; Crowston and Howison, 2005).

Researchers have asked themselves why people write code for free, and why companies invest in OSS projects. After surveying 146 Italian firms supplying OSS, Bonaccorsi and Rossi (2004) found significant differences between motivations of individuals to contribute to OSS projects and those of firms. Economic and technological reasons drive firms to contribute and are not subject to many social motivations that are typical of individual programmers. Rossi and Bonaccorsi (2005) summarized the OSS literature and provided excellent lists of developer motivations and firm motivations to participate in OSS projects.

Developers' motivations to contribute to OSS projects include (Rossi and Bonaccorsi, 2005):

- Low opportunity costs, monetary rewards

- Reputation among peers

- Future career benefits

- Learning 
- Contribution from the community

- Technological concern

- Filling an unfilled market

- Fun to program

- Altruism

- Sense of belonging to the community

- Fight against proprietary software

Firm's motivations to contribute to OSS projects include (Rossi and Bonaccorsi, 2005):

- Independence from price and license policies of large software companies

- Supplying software-related services

- Selling related products

- Exploiting R\&D activity of other developers and OS firms

- Software testing by the community of users

- Hiring good open source technicians

- Lowering hardware costs

- Security concerns

- Conforming to the values of the open source community (not betraying the trust of other developers)

- Code sharing with the community (reciprocating to sustain cooperation)

- Fighting for software freedom (reducing the market share of large software companies) 
An OSS is covered by an open source license. Dozens of different types of OSS licenses exist ${ }^{8}$. Some licenses are more restrictive than others. GPL, LGPL, and BSD are the licenses most commonly used. GPL is the most restrictive license among these three. Code that uses code covered by a GPL license is required to be put back to the public domain. Lesser GPL relaxes the requirement that if the code is independent of the LGPL-covered code, they don't have to be put back to the public domain. It is suitable for library distribution. BSD is the least restrictive license among these three. BSD-covered code can be used in a proprietary code base without requiring code to be put back (Lerner and Tirole, 2002; Pearson, 2002; Hawkins, 2004).

\subsubsection{Problems with OSS}

Problems with OSS include: fragmentation (e.g., more than a dozen of slightly incompatible Linux versions are available), conflict among developers, poor performance of technically boring modules (user interface is not friendly), poor documentation, feature creep and centralization, and religious blindness (Berroukow, 1999; Levesque 2004).

\subsection{Lessons learned}

Lessons learned from reviewing the literature include:

\footnotetext{
${ }^{8}$ As of March 22, 2007, 58 licenses approved OSS licenses are listed on Open Source Initiative's web site. http://www.opensource.org/licenses/
} 
1. OST companies have not been studied before. A software company that anchors its business around OSS is relatively a new phenomenon, and a telecommunications company that anchors its business around OSS is even newer. It has not been studied by academics previously

2. Product innovation theory is mature. Innovation theory has been studied by various well-known scholars, and it has moved from the descriptive stage to the normative stage. Researchers have not only outlined criteria to identify disruptive innovations, they also have suggested strategies on how to deal with disruptive innovations

3. Managing an asset that the company does not own is becoming more and more important in the interconnected network world. A company has to coordinate its effort with other players in the market. In the open source world, it is even more important and also more difficult to manage open source communities and code contributors

4. Open source has changed competition venues. Since the code is available to the public, companies have to find a new way to compete

5. Venture investments in OSS companies have not been studied. Different types of VCs invest in OSS companies for different reasons. Reasons why 
VCs invest in open source companies and why open source companies seek VC investment are not known

6. OSS is a process innovation. Proprietary software produced by the "cathedral" method and OSS produced by the OSS community in the "bazaar" method have similar functionalities. Software's functionalities do not change much, what changes is the way the software was produced. The OSS often mimics the proprietary software's fit, form, and function

7. OSS is not necessarily free from the problems that proprietary software has. One fundamental problem with Linux is that a dozen slightly incompatible versions exist in today's market 


\section{RESEARCH METHOD}

This research is descriptive and exploratory (Christensen, 2006). The method used in this research follows Eisenhardt (1989). Section 3.1 presents the unit of analysis. Section 3.2 presents the study period. Section 3.3 lists research steps. Section 3.4 explains how the research questions were identified. Section 3.5 explains why the theoretical perspectives were selected. Section 3.6 discusses how data were collected. Section 3.7 describes how data was analyzed. Section 3.8 explains how the data was examined to make inferences about the type of disruptive innovations OST companies represent. And section 3.9 describes how insights were generated.

\subsection{Unit of analysis}

The unit of analysis is a company that:

1) has at least one commercial product offering in the telecommunications market

2) depends on OSS to provide the commercial offering

\subsection{Study period}

The study period covers ten years, and it is from April 1997 to April 2007.

\subsection{Research steps}

To answer the five research questions and generate insights, the following steps were undertaken:

1. Identify research questions 
2. Select theoretical perspectives

3. Collect data

i. Determine criteria for sample selection

ii. Find companies to be in the sample

iii. Collect data on each company

iv. Describe companies in the sample

v. Identify OST companies' product market categories

vi. Collect data on OSS projects in categories identified in the previous step

4. Analyze data

i. Examine the nature of the relationship between the company's commercial product and the OSS, and categorize these relationships

ii. Examine the nature of the relationship between an OST company and the OSS project upon which the company's commercial offers depend, and categorize these relationships

iii. Identify the reasons why a VC invests in an OST company and the reasons why an OST company seeks VC investment

iv. Identify ways OST companies use OSS to generate revenue

v. Identify the benefits and risks of an OST company that depends on OSS

vi. Identify communities anchored around OST companies that directly compete with one another

5. Asses the type of innovations that OST companies represent 


\section{Generate insights}

\subsection{Identify research questions}

The telecommunications market is different from the software market in terms of complexity, failure penalty and network dependency. The author works for a telecommunications company, and was interested to know how OST companies make money using OSS. After reviewing the literature, the author concluded that little was known about OST companies.

The following research questions were identified:

1. What type of innovations do OST companies represent?

2. What type of relationships do commercial offerings of OST companies have with the open source projects upon which they depend and what type of relationships do OST companies have with the OSS projects upon which they depend?

3. What are the reasons that VC firms invest in OST companies and what are the reasons that OST companies search for venture capital?

4. How do OST companies use OSS to make money?

5. What are the benefits and risks of OST companies that depend on OSS for their revenue?

\subsection{Select theoretical perspectives}

The latest development in innovation theory was disruptive innovation theory. It outlined three litmus tests to decide if an innovation is disruptive. This research is 
to assert if OST companies represent a disruptive innovation and if yes, what types of disruptive innovation they represent. It was deemed that disruptive innovation theory is appropriate for this research.

OST companies have emerged in certain product markets and not in others. Modularization theory was selected to explain the reason why OST companies have appeared in certain market segments and not in others.

\subsection{Collect data}

\subsubsection{Determine criteria for sample selection}

For a company to be included in the sample, it had to meet the following criteria:

- The company had to be an active OST company in April 2007

- The OSS project upon which the company's commercial offerings rely had to be active in April 2007

- Data on company's VC funding, commercial products, OSS project on which its commercial products depend had to be available from the Internet

\subsubsection{Find companies to be in the sample}

A suitable OST company database does not exist. A well-recognized industry magazine, InfoWorld, was only able to identify three OST companies in its special report on OSS in August $2005^{\circ}$.

\footnotetext{
${ }^{9}$ OSS are classified into twelve product categories, such as business process management, content management, CRM, ERP, identity, directory, portals, point of sale, RFID, VoIP/Telephony. Out of the 12
} 
To find OST companies, the following activities were carried out:

- The 127 OSS projects included in the IP telephony category on the largest open source project listing website, freshmeat.net, were examined. The OSS project's name was entered as the keyword in the Google search engine and the first two result pages were read to identify companies that commercialize the OSS from the project

- The following key words "open source router", "open source switch", "OST", "open source IP telephony" were entered into the Google search engine and the first four pages of each of the results were read to find companies that commercialize the software from the project

- A snow-ball search was carried out to find new OST companies. For example, the author found five names of potential OST companies from an article named "Here comes open source telecom"10. Then the author did a Google search with each company's name as the keyword, and examined the first two pages to find companies that may be OST companies

categories, 2 categories are in telecom domain, RFID and telephony. The magazine did not find any company that commercialize RFID OSS project. (Only one RFID OSS project was identified and it was still in planning stage at that time.) http://akamai.infoworld.com/pdf/special_report/2005/32SRoss.pdf ${ }^{10} \mathrm{http} / /$ gigaom.com/2006/02/23/here-comes-open-source-telecom/ 


\subsubsection{Collect data on each company}

Sources of data collection include companies' web sites, OSS projects' web sites, press releases, analysts' reports, blogs, wikis, FAQs (Frequently Asked Questions), and emails posted on-line.

For each company, the following information was collected:

- How the company came to being, who the founders were, patents a company filed, revenue, and number of employees

- Ways a company releases its code to the OSS community, and features of the company's commercial version and the OSS version

- Names of venture capitalists that invested in the company, amount of money invested, year in which the investment was made, reasons cited by VCs to invest in the company, reasons cited by the company seeking VC investment

- Details of product offerings related to the OSS upon which they depend

- Benefits and risks of depending on OSS to generate revenue stated by the company

- Names of (i) company's partners, (ii) OSS project upon which the company's commercial products depend on, and (iii) the OSS projects in which the company invests

A company normally issues a news release after it secures VC investment, or there are executive interviews and analyst coverage after a round of $\mathrm{VC}$ investment in a company. Typically the reasons why VCs invest in a certain 
company are explained in those news release, analyst coverage, or executive interviews. The reasons why a company seeks VC investment are also mentioned in those news releases and interviews.

Information on how an OST company uses OSS to make money was collected using two methods: (i) examining a company's product offering and revenue sources, and (ii) examining analysts' reports, and executive interviews. Information on product offerings and revenue sources are available from a company's website.

Typically, companies publicly state the benefits they expect to gain by being OSS companies. Sometimes companies identify the risks associated with depending on OSS. Typically, however, risks of being an OSS company are not stated publicly.

\subsubsection{Describe companies in the sample}

For each company in the sample, the following information was prepared:

- Company overview, including company history, founder information, and VC investment, patents filed

- Revenue sources

- Ecosystem, including information on commercial solution partners and OSS community

- Benefits and risks

- Relationship between commercial offering and the OSS project 


\subsubsection{Identify OST companies' categories}

OST companies were categorized based on the functionality of their commercial products. For example, Digium was categorized as an IP telephone company because its products offer customers an IP telephone system.

\subsubsection{Collect data on OSS projects}

Data on OSS projects listed at OSS listing website, freshmeat.net, in categories identified in the previous step were collected. For each OSS project, the following information was collected:

- OSS project development status

- OSS license type

\subsection{Analyze data}

\subsubsection{Examine relationships}

For each company, the author examined how the company released its code to the OSS community and compared the features of company's commercial versions and the OSS. The ways code was released and the feature comparisons were categorized into different types.

The author identified the role an OSS project played when an OST came to being, and the role the company plays in the support of the OSS project. These roles were categorized into different types. 


\subsubsection{Examine VC investment}

The author examined news releases, executives' interviews and analysts' reports on OST companies' VC investments. The author started with no category and added a new category when reasons stated by VCs when they invested in an OST companies did not fall into an existing category. The reasons why OST companies sought VC investments were identified using a similar method.

\subsubsection{Identify ways OSS is used to make money}

The author examined OST companies' revenue sources, and categorized how OSS was used to help generate these revenues. The author started with no category, and added a new category if the way OSS was used did not fall into an existing category.

\subsubsection{Identify benefits and risks}

The author examined all the benefits publicly stated by OST companies and categorized them. The author started with no category, and added a new category when benefits stated by OST companies did not fall into an existing one. The risks stated by OST companies were organized into categories using a similar method.

\subsubsection{Identify communities anchored around OST companies}

OST companies listed their solution partners in their websites. The author examined partners of OST companies in the same product categories, and 
constructed OST company communities anchored around different OSS projects which compete in the same product domain.

\subsection{Asses the nature of disruptiveness using theory}

First, the author carried out disruptive innovation litmus tests on each product category that has OST companies in it. Then the same litmus tests were carried out for all OST companies in the sample.

The author used modularization theory to explain why OST companies occur in certain product markets and not others.

\subsection{Generate insights}

After the five research questions were answered, the author drew a set of insights from the data collected. 


\section{RESULTS}

This chapter presents the results of this study. Section 4.1 describes the sample used in this research. Section 4.2identifies the relationships between an OST company's commercial offerings and the OSS upon which they rely and the relationships between the OST company and the OSS project. Section 4.3 identifies the various types of VC organizations that invest in OST companies the reasons why OST companies seek VC investment and the reasons why VCs invest in OST companies. Section 4.4 presents ways OST companies use OSS to make money. Section 4.5 presents the benefits and risks of generating revenue relying on OSS. Section 4.6 presents location of OSS projects and OST companies in the network.

\subsection{Sample}

identifies the OST companies used in this research. For each company, it shows whether or not the company received $\mathrm{VC}$ funding or filed patens, the name of the OSS project on which its products depend, the type of commercial products that generate revenue, and the market segment to which the company belongs. Seven out of the ten OST companies in Table 2 have received VC investment, and four have filed patents. Appendix A provides profiles for the ten OST companies in the sample. The headquarters of eight OST companies are located in th USA, one is in the UK, and one is in Australia. 


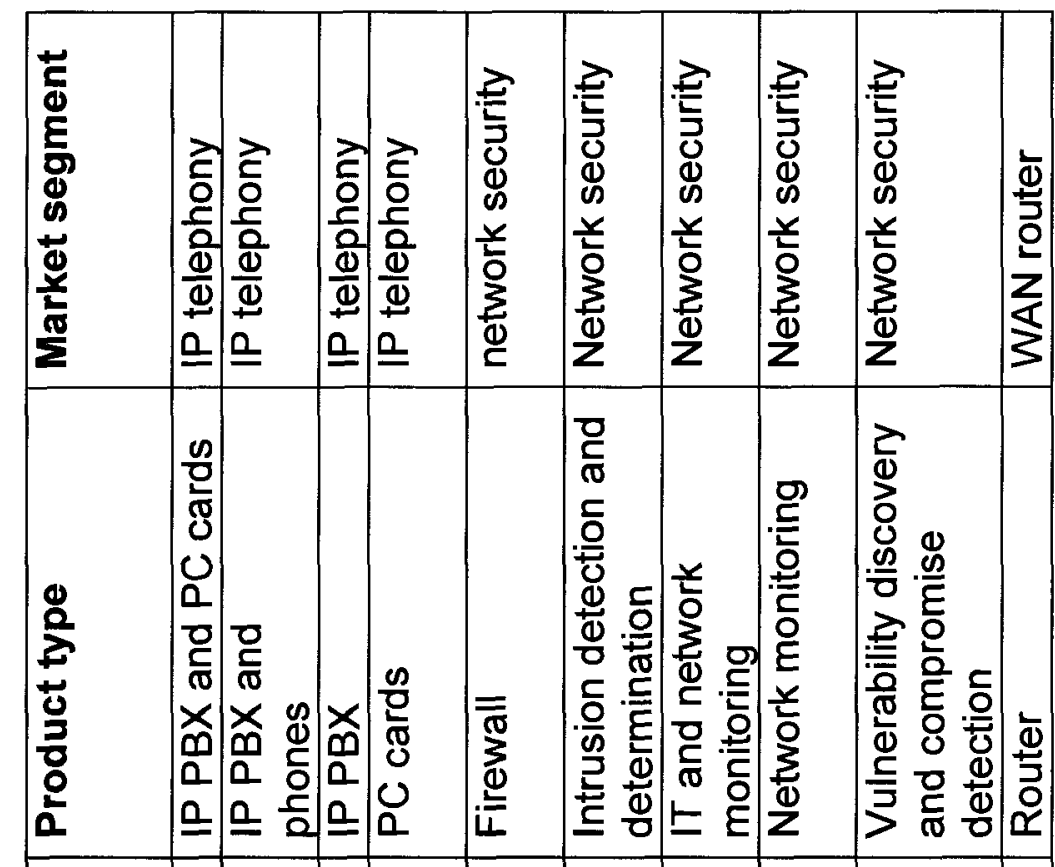

\section{응}

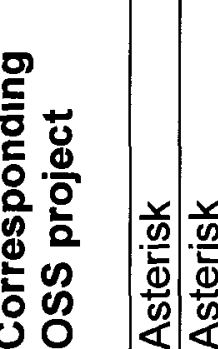
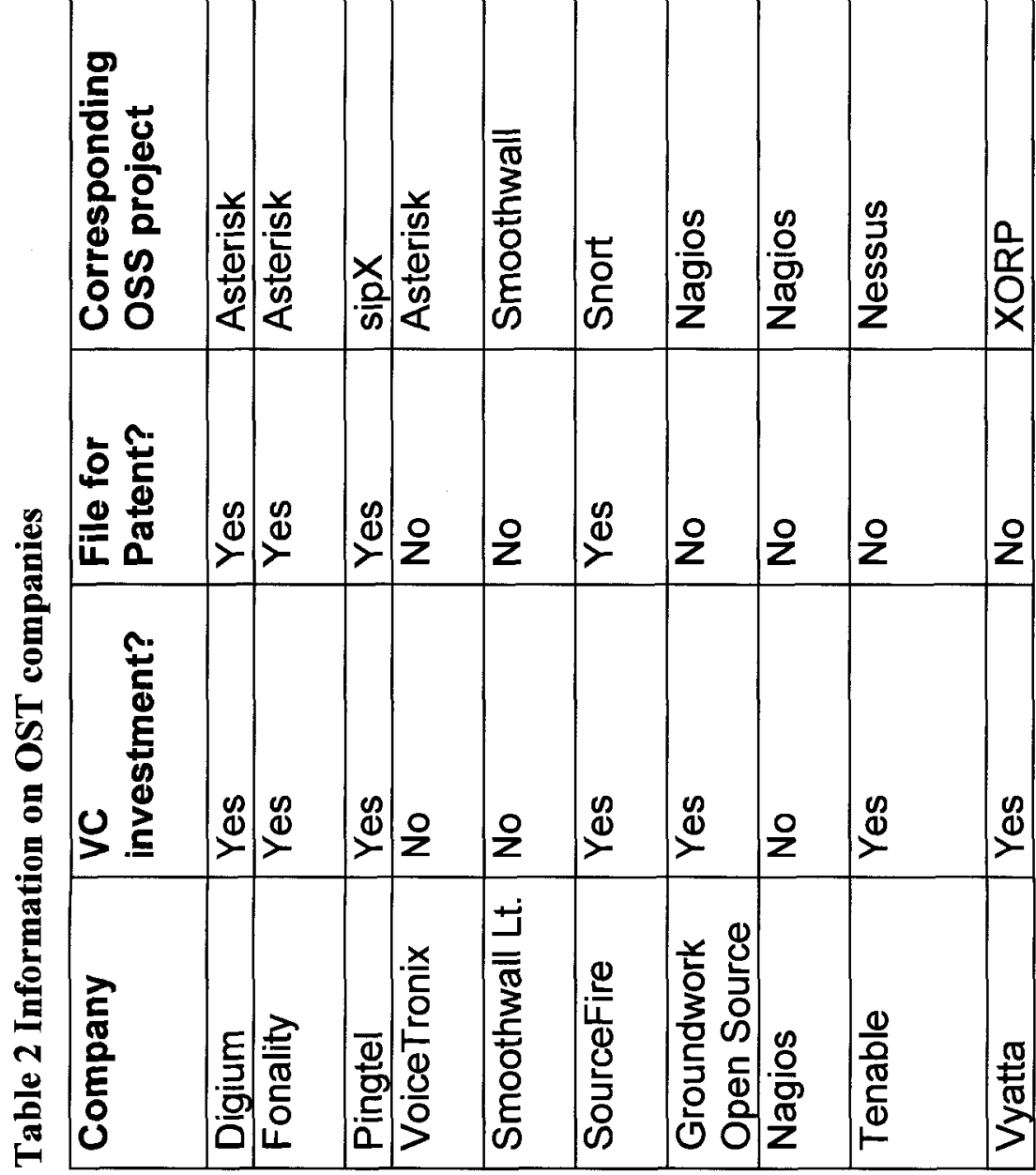
The OST companies in Table 2 were organized into three market segments based on the nature of their commercial products. Companies with products that provided VolP functionalities were placed in the IP telephony market segment. Companies with products that monitored a network, reported abnormal situations in a network, or provided firewall protection were placed in the network security market segment. Companies with wide area network (WAN) router products were placed in the WAN router market segment.

\subsection{Relationship}

\subsubsection{Relationship between commercial offering and OSS}

Appendix B provides descriptions for the ten companies in the sample. The information in Appendix B indicates that timing or available feature set define the relationship between a commercial offer and the OSS upon which it depends.

Table 3 identifies the three types of relationships between commercial offers and OSS that exist.

Table 3 Relationship between commercial offer and OSS

\begin{tabular}{|l|c|}
\hline Relationship & Examples \\
\hline $\begin{array}{l}\text { Updates to the commercial product } \\
\text { are first released to paying customers } \\
\text { and subsequently released to the } \\
\text { open source project }\end{array}$ & $\begin{array}{l}\text { Sourcefire releases security } \\
\text { update to OSS five days later } \\
\text { than to its paid customers }\end{array}$ \\
- $\begin{array}{l}\text { Smoothwall Ltd progressively } \\
\text { releases commercially } \\
\text { developed features back into the } \\
\text { GPL version } \\
\text { Vyatta releases patches and } \\
\text { updates every six months to its } \\
\text { OSS version } \\
\text { - Tenable releases its update to } \\
\text { OSS seven days later than to its }\end{array}$ \\
\hline
\end{tabular}




\begin{tabular}{|c|c|}
\hline & paid customers \\
\hline $\begin{array}{l}\text { The commercial product has more } \\
\text { features than the OSS on which it } \\
\text { depends }\end{array}$ & $\begin{array}{l}\text { Tenable releases certain } \\
\text { features only to its closed-code } \\
\text { release, version } 3 \\
\text { - Pingtel only supports toll-quality } \\
\text { feature in its commercial offering } \\
\text { - Groundwork Open Source } \\
\text { released its Groundwork Monitor } \\
\text { Open Source, as an entry level } \\
\text { product, users pay for } \\
\text { company's high-end products: } \\
\text { Groundwork Monitor } \\
\text { Professional and Groundwork } \\
\text { Monitor Small Business }\end{array}$ \\
\hline $\begin{array}{l}\text { The commercial product and the OSS } \\
\text { have the same functionality, however, } \\
\text { the commercial product has been } \\
\text { tested rigorously }\end{array}$ & - Digium \\
\hline
\end{tabular}

\subsubsection{Relationship between an OST company and its corresponding OSS project}

Information in Appendix B indicates that an OST company and an OSS project can relate to each other in one of the two ways shown in Table 4.

First, an OST company can be the care giver of the OSS project. In this type of relationship, the company may be the result of an unexpected or unplanned success of an open source project. The company was either created or refocused to provide commercial offers anchored around the open source software. This type of relationship includes the instances in which a company released its proprietary code to an open source project and becomes an open source company. Examples of this type of company-project relationship include: Digium 
and Asterisk, SourceFire and Snort, Pingtel and sipX, and Smoothwall Ltd and Smoothwall. Second, an OST company could develop around an OSS project a company did not initiate or previously maintain. Examples of this type of company-project relationship include: Vyatta and XORP, Fonality and Asterisk, and Groundwork Open Source and Nagios.

Table 4 Relationship between an OST company and OSS project

\begin{tabular}{|l|l|l|}
\hline \multirow{4}{*}{ Relationship type } & \multicolumn{2}{|c|}{ Examples } \\
\cline { 2 - 3 } & Company & Open source project \\
\hline \multirow{4}{*}{$\begin{array}{l}\text { gST company is the care- } \\
\text { give OSS project }\end{array}$} & Digium & Asterisk \\
\cline { 2 - 3 } & Sourcefire & Snort \\
\cline { 2 - 3 } & Pingtel to & sipX \\
\cline { 2 - 3 } & Smoothwall Ltd & Smoothwal \\
\cline { 2 - 3 } & Nagios & Nagios \\
\hline $\begin{array}{l}\text { OST company develops } \\
\text { around an OSS project it } \\
\text { did not initiate }\end{array}$ & Vyatta & XORP \\
\cline { 2 - 3 } & Fonality & Asterisk \\
\cline { 2 - 3 } & Grounwork Open Source & Nagios \\
\hline
\end{tabular}

\subsection{OST company and capital suppliers}

\subsubsection{Types of venture capitalist}

Appendix $C$ provides a list of the VCs that invested in the OST companies in the sample. Table 5 provides a summary of the information in Appendix C. Table 5 shows that the diversity of VCs that have invested in OST companies is high, and that the proportion of companies in the sample that received VC investment is 
also high (7 of10). The VCs that invested in OST companies include early and late stage VCs, the corporate venture arms of very large companies, general VC investment companies, VCs that had previous experience investing in OSS and VCs that did not.

Table 5 Types of VC organizations that invested in OST companies

\begin{tabular}{|c|c|c|c|}
\hline \multirow[t]{2}{*}{ Type } & \multicolumn{3}{|c|}{ Examples } \\
\hline & Venture capital & Company & Notes \\
\hline \multirow[t]{4}{*}{ Corporate venture } & Intel Capital & Fonality & VC arm of Intel \\
\hline & SAP Venture & $\begin{array}{l}\text { Groundwork } \\
\text { Open } \\
\text { Source }\end{array}$ & VC arm of SAP \\
\hline & $\begin{array}{l}\text { SAIC Venture } \\
\text { Capital }\end{array}$ & Pingtel & $\begin{array}{l}\text { VC arm of Science } \\
\text { Application } \\
\text { International Corp }\end{array}$ \\
\hline & $\begin{array}{l}\text { Comcast } \\
\text { Interactive } \\
\text { Capital }\end{array}$ & Vyatta & $\begin{array}{l}\text { VC arm of Comcast } \\
\text { Corporation }\end{array}$ \\
\hline \multirow{2}{*}{$\begin{array}{l}\text { Experienced OSS } \\
\text { company investor }\end{array}$} & Matrix Partners & Diguim & Invested in JBoss \\
\hline & SAP Venture & $\begin{array}{l}\text { Groundwork } \\
\text { Open } \\
\text { Source }\end{array}$ & $\begin{array}{l}\text { Invested in MySQL, } \\
\text { RedHat }\end{array}$ \\
\hline $\begin{array}{l}\text { Early stage start-up } \\
\text { investor }\end{array}$ & $\begin{array}{l}\text { Vesbridge } \\
\text { Partners }\end{array}$ & Pingtel & $\begin{array}{l}\text { Focused on the } \\
\text { networking and IT } \\
\text { infrastructure } \\
\text { markets }\end{array}$ \\
\hline $\begin{array}{l}\text { Late stage start-up } \\
\text { investor }\end{array}$ & $\begin{array}{l}\text { Meritech Capital } \\
\text { Partners }\end{array}$ & Sourcefire & $\begin{array}{l}\text { Focused on } \\
\text { information } \\
\text { technology }\end{array}$ \\
\hline Institution investor & $\begin{array}{l}\text { Cross Creek } \\
\text { Capital }\end{array}$ & Sourcefire & $\begin{array}{l}\text { Primarily in late- } \\
\text { stage private equity } \\
\text { transactions }\end{array}$ \\
\hline
\end{tabular}




\begin{tabular}{|l|l|l|l|}
\hline Leading VC & Sequoia Capital & Sourcefire & $\begin{array}{l}\text { Portfolio companies } \\
\text { include Google, } \\
\text { Cisco Systems } \\
\text { Yahoo, eBay, Apple, } \\
\text { Oracle and account } \\
\text { for about 10 percent } \\
\text { of the value of the } \\
\text { Nasdaq }\end{array}$ \\
\hline $\begin{array}{l}\text { VC branch of a } \\
\text { government } \\
\text { department }\end{array}$ & $\begin{array}{l}\text { Maryland } \\
\text { Department of } \\
\text { Business and } \\
\text { Economic } \\
\text { Development's } \\
\text { venture capital } \\
\text { fund }\end{array}$ & $\begin{array}{l}\text { Nenable } \\
\text { Security }\end{array}$ & N/A \\
\hline
\end{tabular}

\subsubsection{Reasons why OST companies seek VC investment}

Table 6 identifies three reasons for OST companies to seek VC investment.

These reasons were identified by examining the information in Appendix B.

Table 6 Reasons why OST companies seek VC investment

\begin{tabular}{|l|l|}
\hline Reasons & Examples \\
\hline Obtain experience and guidance & $\begin{array}{l}\text { Digium has been profitable } \\
\text { since 2002, the reason it took } \\
\text { investment from Matrix } \\
\text { Partners is that Matrix Partners } \\
\text { is the investor behind a } \\
\text { successful OSS company, } \\
\text { JBoss }\end{array}$ \\
\hline Align with network hub & $\begin{array}{l}\text { Fonality vs. Intel Capital } \\
\text { Groundwork Open Source vs. } \\
\text { SAP }\end{array}$ \\
\hline Invest in expansion plan & Sourcefire \\
\hline
\end{tabular}




\subsubsection{Reasons why VCs invest in OST companies}

Table 7 identifies the reasons cited by VCs to invest in OST companies. Table 7 summarizes the information in Appendix B.

Table 7 Reasons why VCs invest in OST companies

\begin{tabular}{|c|c|c|}
\hline Reasons VC invested & VC & Company \\
\hline \multirow{6}{*}{$\begin{array}{l}\text { Provide an alternative to } \\
\text { proprietary solution }\end{array}$} & Matrix Partners & Digium \\
\hline & Cross Creek Capital & Sourcefire \\
\hline & Canaan Partners & $\begin{array}{l}\text { Groundwork Open } \\
\text { Source }\end{array}$ \\
\hline & Mayfield & $\begin{array}{l}\text { Groundwork Open } \\
\text { Source }\end{array}$ \\
\hline & JAFCO Ventures & $\begin{array}{l}\text { Groundwork Open } \\
\text { Source }\end{array}$ \\
\hline & $\begin{array}{l}\text { Comcast Interactive } \\
\text { Capital }\end{array}$ & Vyatta \\
\hline \multirow[t]{3}{*}{ Large OSS base } & Sierra Ventures & Sourcefire \\
\hline & $\begin{array}{l}\text { Core Capital } \\
\text { Partners }\end{array}$ & Sourcefire \\
\hline & Intel Capital & Fonality \\
\hline \multirow[t]{2}{*}{ Product synergy } & SAP Venture & $\begin{array}{l}\text { Groundwork Open } \\
\text { Source }\end{array}$ \\
\hline & Intel Capital & Fonality \\
\hline \multirow[t]{3}{*}{ Excellent top management team } & $\begin{array}{l}\text { Meritech Capital } \\
\text { Partners }\end{array}$ & Sourcefire \\
\hline & Sierra Ventures & Sourcefire \\
\hline & $\begin{array}{l}\text { Core Capital } \\
\text { Partners }\end{array}$ & Sourcefire \\
\hline
\end{tabular}




\begin{tabular}{|c|c|c|}
\hline & & \\
\hline & JAFCO Ventures & $\begin{array}{l}\text { Groundwork Open } \\
\text { Source }\end{array}$ \\
\hline & $\begin{array}{l}\text { Meritech Capital } \\
\text { Partners }\end{array}$ & Sourcefire \\
\hline & $\begin{array}{l}\text { Azure Capital } \\
\text { Partners }\end{array}$ & Fonality \\
\hline & $\begin{array}{l}\text { Comcast Interactive } \\
\text { Capital }\end{array}$ & Vyatta \\
\hline Attractive & Sierra Ventures & Sourcefire \\
\hline & $\begin{array}{l}\text { New Enterprise } \\
\text { Associates }\end{array}$ & Sourcefire \\
\hline & $\begin{array}{l}\text { Azure Capital } \\
\text { Partners }\end{array}$ & Fonality \\
\hline & Sequoia Capital & Sourcefire \\
\hline & $\begin{array}{l}\text { Core Capital } \\
\text { Partners }\end{array}$ & Sourcefire \\
\hline & Cross Creek Capital & Sourcefire \\
\hline & JAFCO Ventures & $\begin{array}{l}\text { Groundwork Open } \\
\text { Source }\end{array}$ \\
\hline & $\begin{array}{l}\text { Comcast Interactive } \\
\text { Capital }\end{array}$ & Vyatta \\
\hline
\end{tabular}




\subsection{Ways OST companies use OSS to make money}

Table 8 identifies the ways OST companies use OSS to make money.

Information in Table 8 was drawn from the information provided in Appendix B.

Table 8 Ways an OST company uses OSS to make money

\begin{tabular}{|c|c|c|}
\hline \multirow{2}{*}{$\begin{array}{l}\text { Ways company uses } \\
\text { OSS to make money }\end{array}$} & \multicolumn{2}{|r|}{ Examples } \\
\hline & Company & Product \\
\hline \multirow[t]{2}{*}{$\begin{array}{l}\text { OST company sells } \\
\text { hardware that is } \\
\text { complementary to the } \\
\text { OSS }\end{array}$} & Digium & $\begin{array}{ll} & \text { TC400B } \\
\text { B410P } \\
\text { - } & \text { TE412P } \\
\text { - } & \text { TE120P } \\
\text { TDM2400P }\end{array}$ \\
\hline & \begin{tabular}{|l|} 
VoiceTronix \\
\end{tabular} & $\begin{array}{ll}\text { - } & \text { OpenPCl-4L } \\
\text { - } & \text { OpenLine4 } \\
\text { - } & \text { OpenSwitch12 }\end{array}$ \\
\hline \multirow{4}{*}{$\begin{array}{l}\text { OST company sells an } \\
\text { appliance that integrates } \\
\text { a PC with OSS }\end{array}$} & Vyatta & $\begin{array}{l}\text { Open flexible router } \\
\text { (OFR) appliance }\end{array}$ \\
\hline & Pingtel & - SIPxchange ECS 50 \\
\hline & Smoothwall Ltd & - SmoothGuard 1000-UTM \\
\hline & Fonality & $\begin{array}{l}\text { - PBXtra standard } \\
\text { - PBXtra professional }\end{array}$ \\
\hline \multirow[t]{3}{*}{$\begin{array}{l}\text { OST company sells add- } \\
\text { ons to the OSS }\end{array}$} & Sourcefire & $\begin{array}{l}\text { Sourcefire intrusion agent } \\
\text { for snort }\end{array}$ \\
\hline & $\begin{array}{l}\text { Tenable Network } \\
\text { Security }\end{array}$ & $\begin{array}{l}\text { Nessus vulnerability } \\
\text { scanner }\end{array}$ \\
\hline & $\begin{array}{l}\text { Groundwork } \\
\text { Open Source }\end{array}$ & $\begin{array}{l}\text { Groundwork monitor } \\
\text { small business } \\
\text { - Groundwork monitor } \\
\text { professional }\end{array}$ \\
\hline $\begin{array}{l}\text { OST company charges } \\
\text { subscriptions for software }\end{array}$ & Pingtel & $\begin{array}{l}\text { Jump start program } \\
\text { Technical assistance }\end{array}$ \\
\hline
\end{tabular}




\begin{tabular}{|c|c|c|}
\hline \multirow[t]{5}{*}{ maintenance and support } & & $\begin{array}{ll} & \text { center (TAC) support } \\
\text { - Specialized TAC support }\end{array}$ \\
\hline & Fonality & $\begin{array}{l}\text { - } 1-4 \text { phones ( } \$ 65 / \text { user } / \\
\text { year) } \\
\text { - } 501-1000+(\$ 38 / \text { user / } \\
\text { year) }\end{array}$ \\
\hline & Vyatta & $\begin{array}{l}\text { OFR enterprise } \\
\text { subscription } \\
\text { - OFR professional } \\
\text { subscription }\end{array}$ \\
\hline & Digium & $\begin{array}{l}\text { 5x8xNBD maintenance } \\
\text { plan } \\
\text { - } 7 \times 24 \times \text { NBD maintenance } \\
\text { plan }\end{array}$ \\
\hline & $\begin{array}{l}\text { Tenable Network } \\
\text { Security }\end{array}$ & - Nessus direct feed \\
\hline $\begin{array}{l}\text { OST company sells } \\
\text { product that complements } \\
\text { products of other } \\
\text { suppliers which are sold } \\
\text { as appliance }\end{array}$ & Nagios & - Azeti-A \\
\hline \multirow{3}{*}{$\begin{array}{l}\text { OST company charges } \\
\text { for customization and } \\
\text { consulting for OSS }\end{array}$} & Pingtel & $\begin{array}{l}\text { - Application support } \\
\text { - Consulting }\end{array}$ \\
\hline & Digium & $\begin{array}{l}\text { - Configuration package } \\
\text { - Customer development } \\
\text { - Digium's consulting }\end{array}$ \\
\hline & Vyatta & $\begin{array}{l}\text { - Remote consulting } \\
\text { service }\end{array}$ \\
\hline $\begin{array}{l}\text { OST company charges } \\
\text { for license }\end{array}$ & Digium & $\begin{array}{l}\text { Asterisk is available } \\
\text { under commercial license }\end{array}$ \\
\hline
\end{tabular}




\subsection{Benefits and risks OST companies have by depending on OSS}

This section identifies the benefits and risks of OST companies.

\subsubsection{Benefits}

Table 9 identifies the benefits to OST companies that generate revenue selling market offers that rely on OSS.

Table 9 Benefits OST companies may accrue

\begin{tabular}{|l|l|}
\hline Benefits & Examples \\
\hline $\begin{array}{l}\text { OSS enables a company to quickly } \\
\text { become a world-wide player }\end{array}$ & Pingtel \\
\hline $\begin{array}{l}\text { OSS enables a small company to } \\
\text { enter a niche market dominated by a } \\
\text { large company }\end{array}$ & $\begin{array}{l}\text { Sourcefire } \\
\text { Vyatta }\end{array}$ \\
\hline OSS decreases time to market & $\begin{array}{l}\text { Fonality released a commercial } \\
\text { product in less than one year } \\
\text { after it was founded } \\
\text { Vyatta released a commercial } \\
\text { router in less than one year after } \\
\text { it was founded }\end{array}$ \\
\hline $\begin{array}{l}\text { OSS attracts a very large user base of } \\
\text { potential customers }\end{array}$ & $\begin{array}{l}\text { Snort has 3 million downloads } \\
\text { Smoothwall has 1million } \\
\text { downloads }\end{array}$ \\
\hline $\begin{array}{l}\text { OSS pulls sales for commercial } \\
\text { hardware }\end{array}$ & $\begin{array}{l}\text { VoiceTronix's hardware } \\
\text { supports Asterisk }\end{array}$ \\
\hline $\begin{array}{l}\text { OSS lowers the price of commercial } \\
\text { products that are derived from it }\end{array}$ & $\begin{array}{l}\text { Fonality's product is half of } \\
\text { similar product from Cisco }\end{array}$ \\
\hline
\end{tabular}




\subsubsection{Risks OST companies may face}

Table 10 identifies the risks faced by OST companies that depend on OSS. The first risk was inferred by the author from the fact that Fonaliy uses code created by Digium and overtook market leadership from Digium. The other three risks were identified from the information available in Appendix B.

Table 10 Risks an OST company may face

\begin{tabular}{|l|l|}
\hline Risks & Examples \\
\hline $\begin{array}{l}\text { A competitor can use the OSS code } \\
\text { developed by the company to } \\
\text { increase its market share }\end{array}$ & $\begin{array}{l}\text { Fonality is the world's largest } \\
\text { Asterisk-based commercial } \\
\text { deployment }\end{array}$ \\
\hline $\begin{array}{l}\text { A competitor can fork the OSS project } \\
\text { initiated by the company and launch a } \\
\text { competing community }\end{array}$ & $\begin{array}{l}\text { OpenPBX is forked from } \\
\text { Asterisk and TrixBox is based } \\
\text { on Asterisk } \\
\text { TrixBox is the world's largest } \\
\text { Asterisk-based community, and } \\
\text { was bought by Fonality }\end{array}$ \\
\hline $\begin{array}{l}\text { A competitor can package OSS into } \\
\text { an appliance without revealing that the } \\
\text { code was developed by the OSS } \\
\text { project the company initiated }\end{array}$ & $\begin{array}{l}\text { Many security product } \\
\text { companies whose business } \\
\text { model simply consists of putting } \\
\text { Nessus on an appliance, writing } \\
\text { a Web interface for it, and } \\
\text { renaming it as their own solution }\end{array}$ \\
\hline $\begin{array}{l}\text { Some customers (existing or potential) } \\
\text { may have policies in place that } \\
\text { prevent them from buying products } \\
\text { that have OSS code }\end{array}$ & $\begin{array}{l}\text { Tenable's customer couldn't buy } \\
\text { its product before its code was } \\
\text { released as closed-source code. }\end{array}$ \\
\hline
\end{tabular}




\subsection{Location of OST companies in the telecommunications industry}

\subsubsection{Telecommunications OSS projects' location in the network}

The world largest OSS listing website and hosting website, i.e., freshmeat.net and sourceforge.net, show categories in access network products only. No category for OSS was deemed to be part of the core network. Table 11 shows that OSS projects only exist at the edge of the network.

Table 11 Telecommunications OSS projects in the network

\begin{tabular}{|l|l|}
\hline Industry source of information & Examples \\
\hline $\begin{array}{l}\text { Freshmeat.net, a main OSS listing } \\
\text { web site }\end{array}$ & $\begin{array}{l}\text { Have categories only in access } \\
\text { network market such as, Internet } \\
\text { Phone, Telephony, and FAX. No } \\
\text { category in core network exists }\end{array}$ \\
\hline $\begin{array}{l}\text { Sourceforge, a main OSS hosting web } \\
\text { site }\end{array}$ & $\begin{array}{l}\text { Have categories only in access } \\
\text { network market such as Internet } \\
\text { Phone, Telephony, Firewall, } \\
\text { Monitoring, and Wireless. No } \\
\text { category in core network exists }\end{array}$ \\
\hline
\end{tabular}

\subsubsection{Location of OST companies in the network}

Based on their product offerings functionality, OST companies were classified into three categories: IP telephony, network monitoring market, and WAN router. The first two categories belong to the access network segment. Nine of the ten companies in the sample fall into this market segment. The last category belongs to the core network, and only one company has products in this segment. Although Vyatta's product offerings belong to core network, its product only 
competes in the outside layer of the core network. Table 12 shows the OST companies and their products by category.

Table 12 OST companies in the network

\begin{tabular}{|c|c|c|}
\hline \multirow{2}{*}{$\begin{array}{l}\text { Location of OST companies in } \\
\text { the telecommunications network }\end{array}$} & \multicolumn{2}{|c|}{ Examples } \\
\hline & Company & Product \\
\hline \multirow[t]{3}{*}{ Network access -- IP telephony } & - Digium & $\begin{array}{ll}\text { Asterisk } \\
\text { Business } \\
\text { Edition }\end{array}$ \\
\hline & - Fonality & - PBXtra \\
\hline & - Pintel & $\begin{array}{l}\text { SIPxchange } \\
\text { ECS }\end{array}$ \\
\hline \multirow[t]{3}{*}{$\begin{array}{l}\text { Network access -- Network } \\
\text { monitoring }\end{array}$} & - Smoothwall & $\begin{array}{ll} & \text { Advance } \\
& \text { Firewall } 2\end{array}$ \\
\hline & - Sourcefire & $\begin{array}{l}\text { Defense } \\
\text { Center }\end{array}$ \\
\hline & $\begin{array}{l}\text { Groundwork } \\
\text { Open } \\
\text { Source }\end{array}$ & $\begin{array}{l}\text { Groundwork } \\
\text { Monitor } \\
\text { Professional }\end{array}$ \\
\hline Core network -- WAN router & - Vyatta & $\begin{array}{l}\text { WAN router } \\
\text { appliance }\end{array}$ \\
\hline
\end{tabular}




\section{DISCUSSION OF RESULTS}

This chapter discusses the results provided in chapter 4 . Section 5.1 answers the five research questions. Section 5.2 provides other interesting findings drawn when carrying out this research. Section 5.3 presents the insights gained from the research. Section 5.4 discusses the status of OST companies.

\subsection{Answers to research questions}

This section provides answers to the five research questions.

\subsubsection{What type of innovations do OST companies represent?}

This question was answered for the:

- Network monitoring market segment

- IP telephony market segment

- Overall telecommunications market

\subsubsection{Litmus tests}

Disruptive innovation theory outlines three litmus tests to determine if an innovation can be shaped into disruptive innovation (Christensen, 2003). Litmus test 1 determines if an innovation can be a new-market innovation, litmus test 2 determines if an innovation can be a low-end market innovation, and litmus test 3 determines if an innovation is disruptive. To be disruptive, an innovation first has to pass a new-market test (litmus test 1) or low-end market test (litmus test 2), and then it has to pass the third litmus test.

1. Litmus test 1 
- Is there a large population of people who historically have not had the money, equipment, or skill to do this thing for themselves, and as a result have gone without it altogether or have needed to pay someone with more expertise to do it for them?

- To use the product or service, do customers need to go to an inconvenient, centralized location?

2. Litmus test 2

- Are there customers at the low end of the market who would be happy to purchase a product with less (but good enough) performance if they could get it at a lower price?

- Can we create a business model that enables us to earn attractive profits at the discount prices required to win the business of these over-served customers at the low end?

3. Test1

- Is this innovation disruptive to all of the significant incumbent firms in the industry? If it appears to be sustaining to one or more significant players in the industry, then the odds will be stacked in that firm's favor, and the entrant is unlikely to win

\subsubsection{Network monitoring market segment}

In this section the author argues that OST companies in the network monitoring market segment represent a new-market disruptive innovation. The assessment is based on the assertion that OST companies in the network monitoring market segment pass two litmus tests, test 1 and test 3 (Christensen, 2003). 
Figure 1 Network monitoring market segment

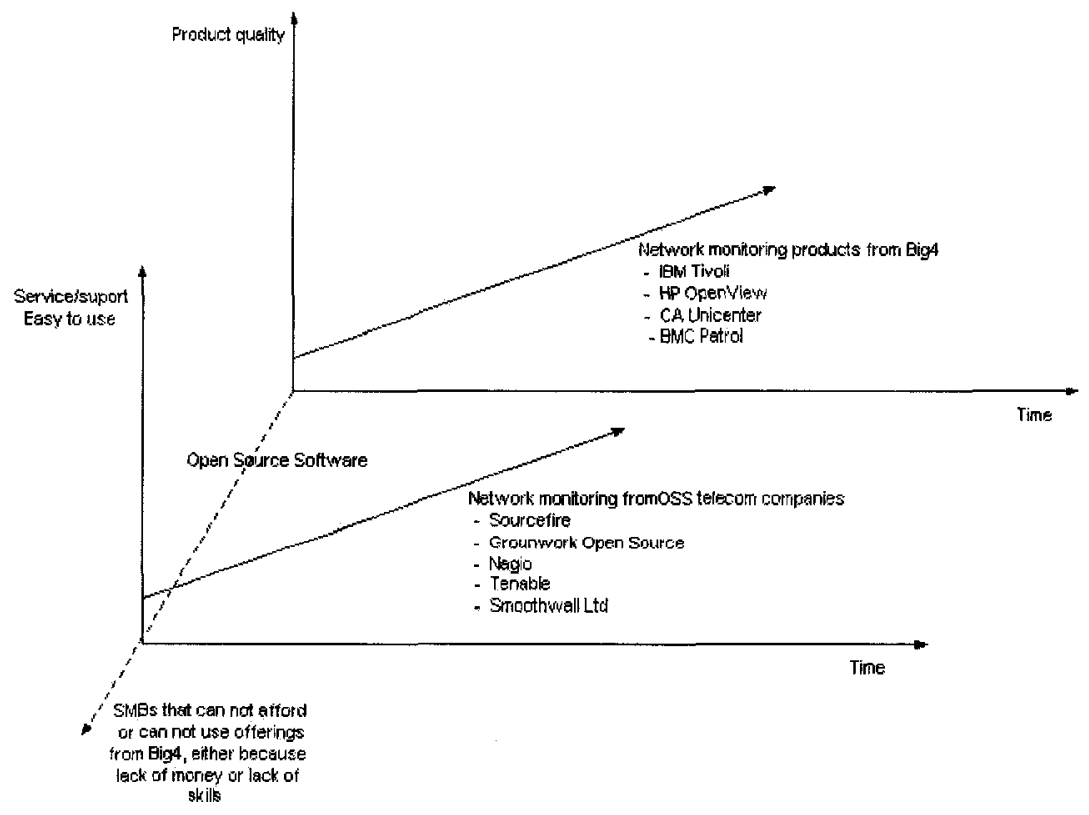

1. Litmus test 1

Small and medium size businesses can not afford solutions from suppliers like the Big4: HP Open View, IBM Tivoli, CA Unicenter, and BMC Patrol.

Open source has enabled small and medium size businesses to purchase network monitoring product to become consumers. Offerings from Big4 are too expensive and too complicated for small and medium size businesses to afford. As a result, they don't use them either because they can not afford them or because they don't have the expertise to use them.

An industry expert observed,

"Most mid-market organizations (including educational institutions) can't afford to shop at the "Big 4" store, it opens up a big market opportunity for open source. Add to that the flexibility and extensibility of open source products that allow companies to "right-size" and customize their IT monitoring and management solutions to fit their specific needs. Being able to do this at a low cost had been a pipe dream for SMB's and smaller enterprises, since most of the solutions 
out there cater to the largest enterprises with the deepest pockets. The availability of open source options is changing that. ${ }^{11}$

2. Litmus test 3

Open source network monitoring is disruptive to all of the incumbents. The new business is built upon OSS, which dramatically

i. Changes a company's cost structure by removing a significant portion of software development cost from a company's R\&D budget

ii. Makes obsolete expensive in-house development skills

iii. Reduces time to market

- Fonality and Vyatta both shipped their first commercial product in less than a year after the companies were founded

- To shorten its development time using OSS, the incumbent needs to change its R\&D skills, product architecture, the product platform, sales and support team, and culture. OSS is disruptive to incumbent players. They can not adjust easily to the new model for developing software. An industry expert put it this way ${ }^{12}$,

"'Asset' layer of monitoring has commoditized, Inflexible, expensive proprietary solutions from the "Big 4" vendors simply do not provide enough additional value, in comparison to open source alternatives, to justify the magnitude more cost."

"Research and development / marketing dollars invested by the "Big 4" vendors are not being devoted to enhancing the infrastructure monitoring software within their IT operations management suite. Rather, the dollars flow up the stack in the areas of IT service

${ }_{11}^{11}$ http://weblog.infoworld.com/openresource/archives/2007/01/on open source.html

12 http://weblog.infoworld.com/openresource/archives/2007/01/on open source.html 
and business processes - areas where open source solutions are nascent and far from mature. It is at these "advise" and "act" layers where large proprietary vendors add real value for customers"

\subsubsection{IP telephony market segment}

In this section the author argues that OST companies in the IP telephony market segment represent a low-end market disruptive innovation. The argument is made on the assertion that OST companies passed two litmus tests, test 2 and test 3

(Christensen, 2003) ${ }^{13}$.

Figure 2 IP telephony market segment

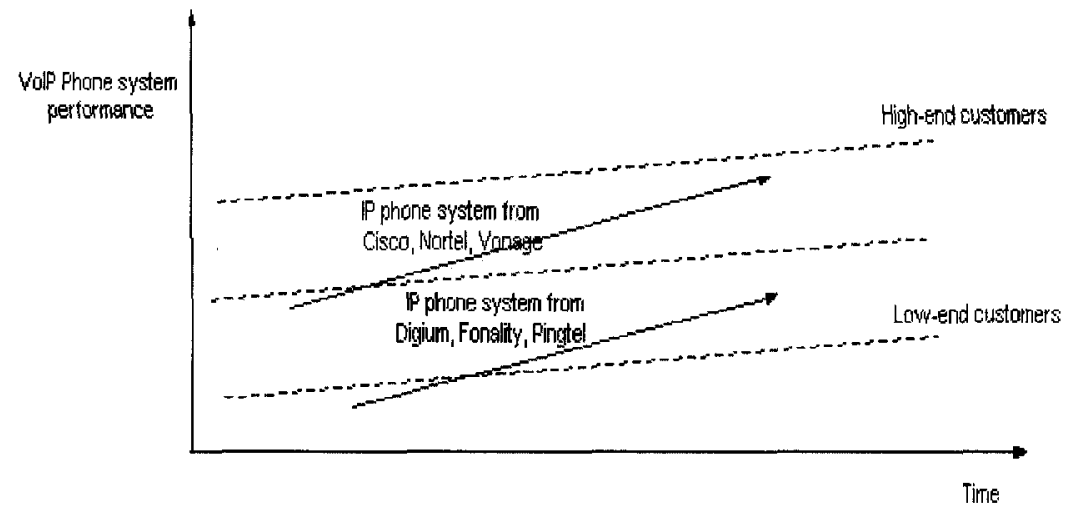

1. Litmus test 2

There are low-end customers who enjoy the good-enough, but much cheaper open source IP telephony alternative. For this reason, both Digium and Fonality are profitable businesses ${ }^{14}$.

\footnotetext{
${ }^{13}$ It's worth pointing out that the Asterisk sometimes provides better performance than Cisco products. As mentioned by an executive, the Asterisk includes a back-up via TDM to the second office if the connection between two offices is severed, and the user wouldn't realize that the connection has been severed. Cisco could only provide this type of backup with duplicate equipment at each office. http://www.computerworld.com/action/article.do?command=viewArticleBasic\&articleld=9004223\&pageN umber $=2$
} 
- Small and medium size businesses are willing to purchase Asteriskbased or sipX-based IP phone systems at a much cheaper price than that available from incumbent players such as Cisco and Nortel

- Companies like Digium, Fonality, and Pingtel have created a business model to win small and medium size businesses by relying on OSS and selling at discounted prices

2. Litmus test 3

Open source IP telephony is disruptive to all the incumbent players. The new business model is built upon OSS, which dramatically

i. Changes the cost structure by removing a significant portion of the software development from a company's R\&D investment

ii. Makes obsolete expensive in-house development skills

iii. Reduces time to market

- Fonality and Vyatta shipped their first commercial product in less than a year after the company is founded

- To shorten its development time using OSS, the incumbent needs to change its R\&D skills, product architecture, the product platform, sales and support team, and culture. OSS is disruptive to incumbent players. They can not adjust easily to the new model for developing software

\footnotetext{
${ }^{14}$ It is worth noting that Christensen deemed IP telephony is a disruptive innovation. He said, "Internet telephony - the packet-switching technology developed by Cisco and others - wasn't good enough to be used in the voice telecommunications market, so it took root in a less demanding application, data transmission. Little by little, it got better and better and now you can send a voice signal over the Internet. That's a good example of a disruptive innovation." http://www.gartner.com/research/fellows/asset_93329 1176.jsp
} 


\subsubsection{OST is low-end disruptive innovation}

The author argues that OST companies represent a low-end disruptive innovation, and that the industry will become a commodity just as the PC industry has become today. The argument is based on the assertion that OST companies passed litmus tests, test 2 and 3 (Christensen, 2003).

\section{Figure 3 Telecommunications market}

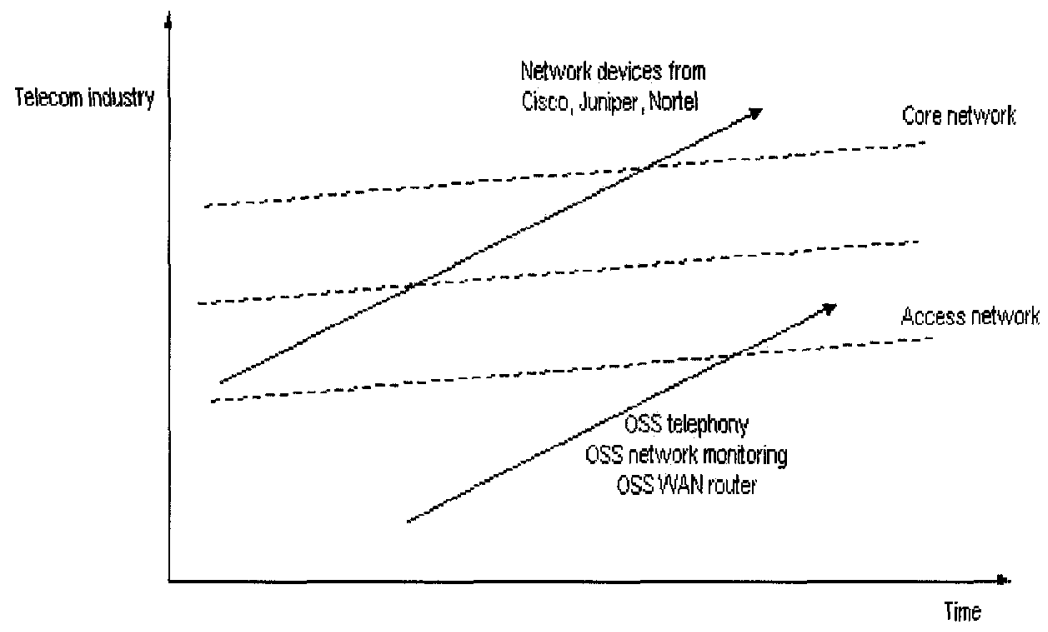

1. Litmus test 2

- Low-end customers of the telecommunications industry, i.e., network access market, are happy to purchase commercial offerings from OST companies. Open source IP telephony and open source network monitoring belong to the network access market, and they have gained significant momentum

- Open source IP telephony and open source network monitoring have proven their business models based on market offers at discounted 
prices. Digium and Fonality both are profitable, and Sourcefire has filed for initial public offering (IPO).

- OST companies hae started to move deeper into the network (or upper telecommunications network layers). Vyatta uses OSS and a commodity PC to provide a WAN router

2. Litmus test 3

The OST is disruptive to all of the incumbent players. The new business model is built upon OSS which

i. Changes the cost structure by removing a significant portion of the software development from a company's R\&D investment

ii. Makes obsolete expensive in-house development skills

iii. Reduces time to market

- Fonality and Vyatta shipped their first commercial product in less than a year after the company is founded

- To shorten its development time using OSS, the incumbent needs to change its R\&D skills, product architecture, the product platform, sales and support team, and culture. OSS is disruptive to incumbent players. They can not adjust easily to the new model for developing software

\subsubsection{OST companies in the router market}

It is too early to tell if the open source router can displace the incumbent players. Only one case was found in this market, and the company is very young. 
Evidence shows that Cisco has felt the pressure of commoditization, and has moved up the value chain to service and architecture design ${ }^{15}$. On the other hand, the SOHO router has long become a commodity market, and vendors like Netgear use OSS to produce their offerings.

One possible reason that will prevent the open source router from taking off could be that the router is a company's communication life line. This is too important of a function to be played with. No organization will place its whole communication system at risk before it is certain that the open source router works properly and reliably.

\subsubsection{Modularization and OST}

Modularization theory (Christensen, 2003) argues that commoditization occurs where true modular interfaces exist. For an interface to be truly modular, it has to meet three conditions: specificability, verifiability, and predictability (Christensen, 2003). After a market becomes a commodity, not much value can be added by reinventing the wheel. OSS is poised to become a viable option for the context, and companies can focus on their core capability to deliver context based on the same content as offered by the OSS platform.

Examining the data through the lens of modular theory, the author argues that modularization has led to the appearance of OST companies. When an interface

\footnotetext{
${ }^{15}$ CEO Chambers has talked about selling services and "architectures" rather than point products, since he expects low-cost challengers to storm the router market. http://www. lightreading.com/document.asp?doc id=119642
} 
becomes modular, commoditization occurs. Modularization and commoditization do not occur overnight, they occur gradually. We can assume that OST companies will start appearing in all market segments where modular interfaces take hold.

\subsection{IP telephony}

Without a clearly defined interface, IP phones from one vendor will not work with IP PBXs from a different vendor. For Asterisk to support IP phones from different vendors, the interface has to be well specified and documented. IP telephony clearly defines and specifies the interface between an IP phone and an IP PBX ${ }^{16}$.

Asterisk works with IP phones from different vendors, including Nortel, Cisco, Mitel, Simense, etc ${ }^{17}$. In contrast, IP PBXs from Nortel only support IP phones from Nortel. For example, BCM200 only support Digital Norstar phones or Nortel IP phones ${ }^{18,19}$. This demonstrates how incumbent players are deeply entrenched in their old way of doing business, i.e., providing vertically integrated solutions, even though the technology and standard have made the market horizontally modular.

\subsection{Network monitoring}

The very nature of data, packet-switched network is layered structure. Its interface is clearly defined in the standard (ITU, IETF, etc). ISO OSI is one good

\footnotetext{
${ }^{16}$ VoIP is a suite of protocols, including but not limited to SIP, H.232, MGCP, etc. Asterisk uses IAX.

${ }^{17} \mathrm{http}: / /$ www.voip-info.org/wiki-Asterisk + phones

$18 \mathrm{http} / /$ www.nortel.com/products/01/eedge/bcm/collateral/nn111380.pdf

${ }^{19}$ http://www.ttechnologyinc.com/phonesystems/bcm/bcm200.asp
} 
example. ${ }^{20}$ One of the most used network management protocol is SNMP, which allows a NMS (Network Management System) to talk to any NEs (Network Element) in the network through a unified protocol ${ }^{21}$.

\subsection{Router}

Request for comments (RFCs) from IETF specify the communication protocols such as routing Information protocol (RIP) and open shortest path first protocol (OSPF). When vendors implement proprietary protocols to gain competing advantages, they publicly specify the interface as well. For example, Cisco implements proprietary HSRP in its routers and it is specified in RFC228122.

The low end of the router market has become a commodity. The SOHO router market has become a commodity, and small and medium size business router is becoming one too. SOHO routers division of Netgear is $\mathrm{OST}^{23}$. Vyatta is evidence that the commoditization in the router market is moving up the ladder.

\subsubsection{Relationship management is key to OST companies}

In addition to the relationship with its commercial partners, an OST company needs to manage two relationships: the relationship between its commercial product offerings and the OSS, and the relationship between the company and the OSS project.

\footnotetext{
${ }^{20} \mathrm{http}: / \mathrm{www}$.howstuffworks.com/osi.htm provides a quick introduction

${ }^{21} \mathrm{http}: / /$ www.dpstele.com/layers/12/snmp 12 tut part $1 . \mathrm{html}$

$22 \mathrm{http} / / \mathrm{www}$.javvin.com/protocol/rfc2281.pdf

${ }^{23}$ Netgear is not included in the sample because the company as a whole does not totally depend on OSS for its product offerings. It deliberately uses OSS. http://kbserver.netgear.com $/ \mathrm{kb}$ web files/open src.asp
} 
An OST company relies on an OSS project for its revenue. The decision of what to release to the OSS project and what to maintain closed is a very difficult one. There is always the risk that if the OST company releases too much or releases updates too early to the OSS project it may lose its paid customers. However, if too little is released to the public domain the OSS project will become unhealthy and inactive. OST companies use OSS to provide an entry level product which is normally good enough for amateur users. This OSS version helps to create a large user base, but it is not solid enough for serious business use.

The priorities of the OSS project and that of an OST company may conflict. Too much emphasis on the company's priority over that of OSS project will hurt the OSS project. Sometimes this can even lead a project to fork from the original one. The OSS community is a loose community whose members join or quit based on their own feelings and judgments. Members contribute to the OSS project because the project appeals to them, most of the time technically. The OSS project creator is very special to the OSS community, and he or she is the one who members look up to. Most OST companies in this research have the OSS project creator play key roles in their companies.

\subsubsection{VC investment in OST companies}

Various types of VCs have invested in OST companies. Although compared with the total amount of VC investment in traditional software the total amount of VC investment in OST companies is insignificant. However, the trend is that OSS 
companies are increasingly attracting VC investment. In 2006, VC investments in OSS companies increase $61.6 \%$ over 2005 . Over the same period of time, VC investment in traditional software business dropped slightly ${ }^{24,25}$.

The attributes of OSS are among the reasons cited by VCs as to why they invest in an OST company. OST companies seek VC investment for reasons other than raising money. Digium sought investment from Matrix Partners because Matrix Partners is the investor that made JBoss a successful OSS company. Digium has faced tough market competition, and it was seeking the business experience and guidance a VC can offer. Other reasons why OST companies sought VC investment include aligning themselves with an industry network hub, and investing in growth. Intel Capital's investment in Fonality and SAP Venture's investment in Groundwork gave both companies access to desirable network hubs.

As the experience of an OSS creator shows, an OST company must have some proprietary content built around OSS for a VC to have something to invest in.

So in 2001 he began courting venture capitalists to see if they would back his plans to start a company to support Snort. When he made the rounds, he says, there were no takers. "They wouldn't go near it unless we had some [proprietary] intellectual content wrapped around Snort," Roesch says ${ }^{26}$.

\footnotetext{
${ }^{24} \mathrm{http}: / / \mathrm{www}$. businessreviewonline.com/os/archives/2007/02/open source fun $2 . \mathrm{html}$

25 http://www.cbronline.com/article cbr.asp?guid=783E7A58-EC19-40D8-8791-0B091E2E0B0B

${ }^{26} \mathrm{http} / /$ www.cio.com/archive/021506/opensource.html?page $=2$
} 


\subsubsection{New way to generate revenue}

An industry expert outlined a list of business models an OSS software company can use (Wu, 2005). Table 8 shows the way OST companies used OSS to generate revenue. Table 13 presents a comparison between those OSS software companies' business modes and those of OST.

Table 13 Comparison between how OSS and OST companies make money

\begin{tabular}{|c|c|c|}
\hline $\begin{array}{l}\text { Way OSS companies } \\
\text { use OSS to make } \\
\text { money }\end{array}$ & $\begin{array}{l}\text { Way OST companies use } \\
\text { OSS to make money }\end{array}$ & Notes \\
\hline $\begin{array}{l}\text { Hosted model: Software } \\
\text { delivered as service that } \\
\text { charged on a periodic } \\
\text { basis (i.e. monthly) }\end{array}$ & N/A & $\begin{array}{l}\text { No OST } \\
\text { company uses } \\
\text { this model }\end{array}$ \\
\hline $\begin{array}{l}\text { Support model: Support, } \\
\text { maintenance and } \\
\text { upgrade type of service } \\
\text { model }\end{array}$ & $\begin{array}{l}\text { Company charges } \\
\text { subscriptions for software } \\
\text { maintenance and support }\end{array}$ & $\begin{array}{ll}\text { - } & \text { Pingtel } \\
\text { - } & \text { Fonality } \\
\text { - } & \text { Dyatta } \\
\text { - } & \text { Tenabium } \\
& \text { Network } \\
& \text { Security }\end{array}$ \\
\hline \multirow{2}{*}{$\begin{array}{l}\text { Hardware model: } \\
\text { hardware solution that } \\
\text { encapsulates open } \\
\text { source function and } \\
\text { deliver as a complete } \\
\text { out-of-the-box solution }\end{array}$} & $\begin{array}{l}\text { Company sells an appliance } \\
\text { that integrates a PC with } \\
\text { OSS }\end{array}$ & $\begin{array}{l}\text { - } \text { Vyatta } \\
\text { - Pingtel } \\
\text { - Smoothwall Ltd } \\
\text { - } \text { Fonality }\end{array}$ \\
\hline & $\begin{array}{l}\text { Company sells product that } \\
\text { complements products of } \\
\text { other suppliers which are } \\
\text { sold as appliance }\end{array}$ & - Nagios \\
\hline $\begin{array}{l}\text { Consulting model: Free } \\
\text { open source, but charge } \\
\text { for consulting }\end{array}$ & $\begin{array}{l}\text { Company charges for } \\
\text { customization and } \\
\text { consulting for OSS }\end{array}$ & $\begin{array}{ll}\text { - } & \text { Pingtel } \\
\text { - Digium } \\
\text { - Vyatta }\end{array}$ \\
\hline Duel license model: free & Company charges for & - Digium \\
\hline
\end{tabular}




\begin{tabular}{|l|l|l|}
\hline $\begin{array}{l}\text { license for developer, but } \\
\text { charge for advanced / } \\
\text { commercial deployment }\end{array}$ & license \\
\hline $\begin{array}{l}\text { Layering model: use } \\
\text { open source to } \\
\text { commoditize the layer } \\
\text { that is not critical or } \\
\text { traditional best provided } \\
\text { by competitor, and } \\
\text { charge for the solution } \\
\text { above it. i.e. oracle on } \\
\text { Linux }\end{array}$ & $\begin{array}{l}\text { Company sells add-ons to } \\
\text { the OSS }\end{array}$ & $\begin{array}{l}\text { Sourcefire } \\
\text { Tenable } \\
\text { Network }\end{array}$ \\
\hline N/A & $\begin{array}{l}\text { Security } \\
\text { Groundwork } \\
\text { Open Source }\end{array}$ \\
\hline
\end{tabular}

Table 13 indicates that OST companies have a unique way to generate revenue, not observed in OSS companies, the sale of preparatory hardware. VoiceTronix and Digium both sell cards that support Asterisk OSS. Without Asterisk, these cards do not offer their customers any value.

OST companies do not host services. The reason for this may be that OST companies are equipment manufactures and not pure software company or webservice companies.

\subsubsection{Benefits and risks}

Compared with the risks identified in a previous TTM thesis (Yang, 2006), there are similar risks in OST, and new benefits were identified. 
As results in section 4.4 show, a new benefits identified in OST is that a company uses OSS as free software to sell its proprietary hardware. Using OSS removed development cost, and was free from vendor lock-in problem. VoiceTronix is the case. It specializes in selling complementary hardware to IP telephony software.

Common risks include incompatible company's objective and OSS community objective such as Asterisk was forked, and companies facing increased competition as witnessed by Digium and Fonality. With the availability of OSS code, the entry bar is much lower. Competitor takes advantage of OSS code created by the focal company and became market leader, as shown in Fonality versus Digum. Telecommunications companies sell equipment, and therefore companies could simply package OSS into an appliance without mentioning it. Tenable claimed that Nessus was packaged into competitors' products and new interface were developed for it so no one could tell they are essentially based on Nessus ${ }^{27}$.

\subsection{Other interesting findings}

\subsubsection{Communities anchored around competing OST companies}

\subsubsection{OSS projects in IP telephony}

A total of 127 OSS IP telephony projects were listed at freshmeat.net under the category of communication and the sub-category of Internet phone. For each

\footnotetext{
${ }^{27}$ A huge risk associated with this strategy is that if it was detected that GPL OSS code is used, the company will be forced to release its proprietary code to the public domain. D-Link has to stop shipment of DSM-G600, http://www.crn.com.au/story.aspx?CIID $=60373$. Another case is that Linksys was forced to release its proprietary code for Wifi router WRT54G, http://www.wifiplanet.com/tutorials/article.php/3562391.
} 
project, there is an about section which provides an introduction about the OSS project. Under each project, the website also provides development status which is decided by project owners, and license type under which the code was released. The author examined each OSS projects' summary and determined that 8 OSS projects can be used to build an IP telephony system. Table 14 presents those platform-capable OSS projects, their development status, and license type.

Table 14 OSS projects in IP telephony

\begin{tabular}{|l|l|l|l|l|}
\hline OSS project & $\begin{array}{l}\text { Develop } \\
\text { ment } \\
\text { Status }\end{array}$ & License & Web site & Added date \\
\hline Ekiga & Mature & GPL & $\underline{\text { http://www.ekiga.org/ }}$ & August 2001 \\
\hline Asterisk & Beta & GPL & $\underline{\text { http://www.asterisk.org/ }}$ & $\begin{array}{l}\text { December } \\
1999\end{array}$ \\
\hline Linphone & N/A & GPL & $\underline{\text { http://www.linphone.org/ }}$ & April 2001 \\
\hline Bayonne & Beta & GPL & $\underline{\text { http://www.gnu.org/softw }}$ & May 2000 \\
\hline SER & Mature & GPL & $\underline{\text { http://iptel.org/ser }}$ & October 2002 \\
\hline sipX & Mature & GPL & $\frac{\text { http://www.sipfoundry.or }}{\mathrm{g}}$ & $\begin{array}{l}\text { February } \\
2005\end{array}$ \\
\hline SFLphone & Alpha & GPL & $\underline{\text { http://www.sflphone.org/ }}$ & December \\
& & & $\underline{\text { http://yate.null.ro }}$ & April 2004 \\
\hline YATE & Mature & GPL & $\underline{y}$ &
\end{tabular}




\subsubsection{OSS projects compete with each other}

As shown in the previous section, many OSS projects can be used to build a phone system. On the other hand, an OSS project can be forked and used by competitors to compete with the original OSS creator. For example, Trixbox was originally known as Asterisk@home, and was built on top of Asterisk. But it was bought by Fonality, Digium's main competitor. Table 15 shows that among OSS projects listed at freshmeat.net, 8 OSS projects can be used to build an IP phone system, 6 are in mature state, and 2 have been commercialized.

\section{Table 15 Competing OSS projects}

\begin{tabular}{|c|c|}
\hline Competing OSS project & Examples \\
\hline $\begin{array}{l}8 \text { OSS projects listed at freshmeat.net } \\
\text { can be used to build an IP phone } \\
\text { system }\end{array}$ & $\begin{array}{l}\text { - } \text { Ekiga } \\
\text { - } \text { Asterisk } \\
\text { - } \text { Linphone } \\
\text { - } \text { SEyonne } \\
\text { - } \text { sipX } \\
\text { - } \text { SELphone } \\
\text { - } \text { YATE }\end{array}$ \\
\hline 6 out these 8 are in mature status & $\begin{array}{ll}\text { - } & \text { Ekiga } \\
\text { - } & \text { Asterisk } \\
\text { - } & \text { Bayonne } \\
\text { - } & \text { SER } \\
\text { - } & \text { sipX } \\
\text { - } & \text { YATE }\end{array}$ \\
\hline $\begin{array}{l}\text { Companies have commercialized } 2 \text { of } \\
\text { the } 6\end{array}$ & $\begin{array}{l}\text { Asterisk } \\
\text { - sipX }\end{array}$ \\
\hline $\begin{array}{l}\text { Competing communities can have the } \\
\text { same root }\end{array}$ & $\begin{array}{l}\text { Asterisk, OpenPBX, TrixBox are } \\
\text { all Asterisk communities } \\
\text { - TrixBox is the largest Asterisk- } \\
\text { based community }\end{array}$ \\
\hline
\end{tabular}




\subsubsection{Two competing OST IP telephony company communities}

Using solution partners listed at Pingtel, Digium, and other companies' web site, the author constructed Figure 4. Digium's website divided its solution partners in two categories: solution community and second layer community. Mainly two groups of open source telephony companies exist ${ }^{28}$. Some companies like Polycom support both OSS projects.

The $\operatorname{sipX}$ approach is a top-down, standard based approach, and it has standard committee's support. On the other hand, the Asterisk approach is a bottom-up, real-world experience approach. It grew more based on users' preferences, rather than standard committees' recommendations. Table 16 compares the two OSS projects.

Table 16 sipX and Asterisk ${ }^{29}$

\begin{tabular}{|l|l|l|}
\hline Dimension & sipX & Asterisk \\
\hline License Type & L-GPL & GPL \\
\hline Inception & $\begin{array}{l}\text { Proprietary code was } \\
\text { released as OSS }\end{array}$ & Born as OSS \\
\hline Standard & $\begin{array}{l}\text { Standard } \\
\text { implementation }\end{array}$ & De facto standard \\
\hline Protocol & SIP & AIX \\
\hline Implementation & Distributed and modular & Centralized control \\
\hline
\end{tabular}

\footnotetext{
${ }^{28}$ YATE is a new OSS project that was started in 2004, and company, Null Team, was created around the OSS project. Phones from Sangoma are supported by its software. But Null Team is in a very early stage, doesn't have much revenue, therefore it's not included in the sample base.

${ }^{29} \mathrm{http}: / /$ sipx-wiki.calivia.com/index.php/Comparing_sipX with Asterisk

${ }^{30}$ Many of the key members of the key IETF working groups also sit on the board of SIPfoundry http://www.theregister.co.uk/2005/05/22/pingtel voip/
} 


\begin{tabular}{|l|l|l|}
\hline & & system \\
\hline Approach & Top-down & Bottom-up \\
\hline
\end{tabular}

Figure 4 Open source IP telephony companies

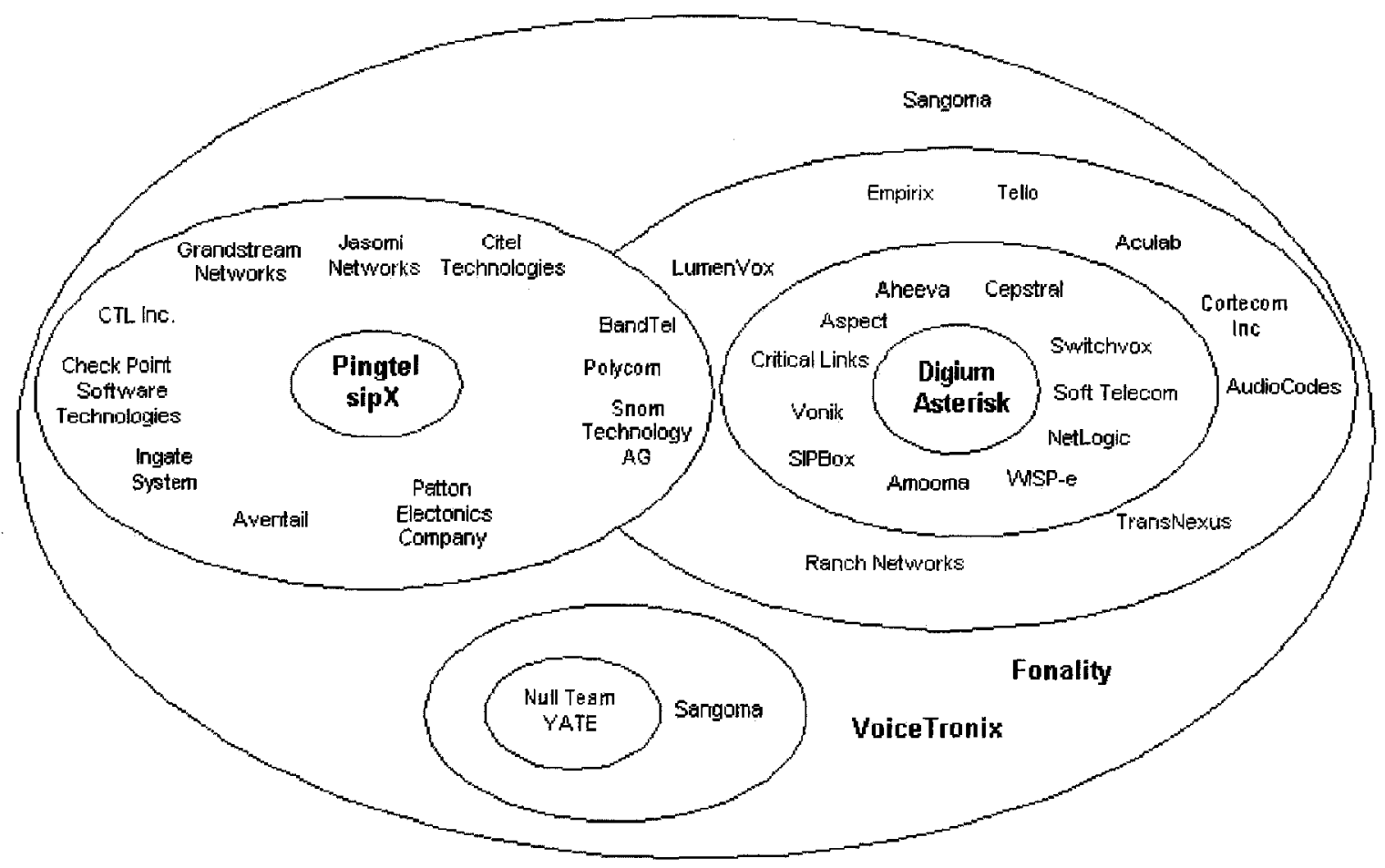

\subsubsection{OST companies and patents}

OST companies also use patents to protect their intellectual property. The author searched google.com with each sample company's name as keyword for patent information. Four companies out of ten OST companies have filed patents. From the applied patents coverage, it seems that OST companies' patents are more likely in the architecture domain. Table 17 presents OST companies that have filed patents and the area that covered by the patents.

Table 17 OST companies that have filed patent 


\begin{tabular}{|l|l|}
\hline OST company & Area covered by patent filed \\
\hline Sourcefire & $\begin{array}{l}\text { - Threat and network discovery } \\
\text { Fonality }\end{array}$ \\
\hline Digium & $\begin{array}{l}\text { Hybrid managed services } \\
\text { architecture }\end{array}$ \\
\hline Pingtel & $\begin{array}{l}\text { VoiceBus }{ }^{\text {TM }} \text { architecture } \\
\text { network including one or more } \\
\text { telephony communications } \\
\text { Method and system for combining } \\
\text { configuration parameters for an } \\
\text { enter profile }\end{array}$ \\
\hline
\end{tabular}

\subsubsection{OST companies' attributes}

\subsubsection{OST companies' TMT}

All the OST companies provide information about their Top Management Team (TMT) at their websites. A TMT member is classified as technology guru if she or he is the OSS project initiator or owner, or she or he technologically contributes to the OSS project, otherwise she or he is classified as business manager. A company's TMT is classified as technology guru type if the majority of TMT members are technology gurus. At the other extreme is business executive type if none of TMT is technology guru. In the middle is the mixed type, in which TMT consists of both tech gurus and business executives. The author examined each company's TMT, and classified them into three types as show in Table 18.

\section{Table 18 Types of TMT}

\begin{tabular}{|l|l|}
\hline Who is key in company's TMT & Examples \\
\hline Technology guru who initiated and leads & - Digium, until Jan 2007 \\
\hline
\end{tabular}




\begin{tabular}{|l|l|}
\hline the OSS project & \\
\hline Executives with business backgrounds & - Vyatta, \\
& - Fonality \\
\hline $\begin{array}{l}\text { Mix of technology gurus and executives } \\
\text { with business backgrounds }\end{array}$ & - SourceFire \\
& - Pigium, after Jan 2007 \\
& Pingtel Network Security \\
\hline
\end{tabular}

\subsubsection{OSS creator is a special asset to an OST company}

Many OST companies are not a result of well executed business plan. Instead they are results of unexpected success of OSS projects. OSS project creators are very special assets to the companies that commercialize the OSS. The OSS project creator serves as a leader to both the community and the company. Table 19 lists OSS projects, their creators and their roles in the companies that commercialize the OSS project.

Table 19 OSS project creator and the company

\begin{tabular}{|l|l|l|l|}
\hline OSS project & Creator & Role & Company \\
\hline Asterisk & Mark Spencer & $\begin{array}{l}\text { CTO and } \\
\text { chairman }\end{array}$ & Digium \\
\hline Snort & Marty Roesch & CTO & Sourcefire \\
\hline Nagios & Ethan Galstad & Owner & Nagios \\
\hline Nessus & Renaud Deraison & CTO & $\begin{array}{l}\text { Tenable Network } \\
\text { Security }\end{array}$ \\
\hline Smoothwall & $\begin{array}{l}\text { Lawrence } \\
\text { Manning }\end{array}$ & $\begin{array}{l}\text { Lead } \\
\text { Developer }\end{array}$ & Smoothwall Ltd. \\
\hline
\end{tabular}




\subsection{Insights}

The author gained the following insights from carrying out this research:

1. OST companies represent different types of disruptive innovation

- Open source network monitoring is a new-market disruptive innovation

- Open source IP telephony is a low-market disruptive innovation

- Open source has moved deeper into the network

2. Ability to manage assets that a company does not own is becoming more important

- OST companies need to manage more relationships such as the one between its own priorities and the OSS project's priorities

- OST companies provide new opportunities to OSS community, such as job opportunities for developers and cool design ideas becoming real world products

3. Diversity of VCs that invest in OST companies is high; and proportion of OST companies that received VC investment is high

4. OST companies are new entrants to the telecommunications industry. All OST companies identified in the sample are new entrants. No incumbent telecommunications company was found that has adopted OST at company strategy level, i.e., entered collaborate or redefine stage as defined in Carbone (2007)

5. OST companies use patents for intellectual protection, and they tend to be in the system architecture domain 
6. Penalty for failure is much higher in telecommunications market than that in software market. Risk sharing and professional support are very important in the telecommunications market, and this exposes the OST companies the likelihood that can generate revenue

7. OSS communities compete with each other. OST companies anchored around a certain OSS project compete with each other also

8. Selling complementary hardware is a new way to make money for OST companies, which is not available to OSS companies

9. Building a company around an OSS project is a new way for tech-savvy entrepreneurs to start a business venture. They can either start an OSS project or use platform-capable OSS projects that already exist

\subsection{Status of OST companies}

Although open source has shown signs of being a disruption to the traditional telecommunications market, it has not shaken up the existing status quo yet (Chakravorti, 2003). To become a real disruptive force, it has to shake up the existing equilibrium and build a new one at the same time. OST companies are still at an early stage. Given that OST companies have gained wide recognition but have not been widely deployed, the author argues that they have past the chasm and entered the bowling alley stage, but they have not entered the tornado stage yet (Moore, 2002, 2004).

There are two different ways that strategy is formulated: emergent and deliberate (Christensen, 2003). As identified in this research, some open source companies 
are the result of an unexpected success of an OSS project, and some OST companies are the result of a conscious management decision and business plan execution.

One key factor to successfully leverage open source in telecommunications market is to successfully manage the relationship with the open source community. As lansiti (2004) pointed out, managing assets that one does not own is becoming more and more important. How to manage this relationship and to make good use of a world-wide resource pool that a successful open source project community can offer is key to an OST company's success. Communities of OST companies were identified in this research. Each community has a core company which acts as a keystone to its ecosystem (lansiti , 2004), or serves as a platform leader to its group (Gawer, 2002). The effort made by those core companies to maintain the health of its community is vital to the overall success of that group of companies and the corresponding OSS project. These keystone companies can not put too much of its own priorities over that of the OSS community and OSS project. No matter how an open source company came to life, its success closely relates to the health and success of the OSS community and OSS project upon which it depends. OST companies have to manage their relationships between with OSS projects efficiently and productively. How to manage the OSS community that a company does not own needs top management team's attention. 
The author believes that OST companies have past the market recognition chasm but have not gained main stream deployment yet. OST companies will move up the product chain and gain more market share eventually. Chris Lyman, CEO of Fonality, pointed out: "Open source is a force that can't be stopped.

When it picks a market it eats it out from the bottom up" 


\section{CONCLUSIONS, LIMITATIONS AND SUGGESTIONS FOR FUTURE RESEACH}

\subsection{Conclusions}

This research answered the following research questions:

1. What type of innovations do OST companies represent?

2. What type of relationships do commercial offerings of OST companies have with the open source projects upon which they depend and what type of relationships do OST companies have with the OSS projects upon which they depend?

3. What are the reasons that venture capital firms invest in OST companies and what are the reasons that OST companies search for venture capital?

4. How do OST companies use OSS to make money?

5. What are the benefits and risks of OST companies that depend on OSS for their revenue?

OST companies were deemed to be disruptive innovations in two access network markets. Moreover, OST companies were deemed to be disruptive to the traditional telecommunications industry. Modularization theory was used to explain that OST companies occurred in these access markets because modular interfaces exist in them.

Traditional telecommunications companies can not ignore OST companies although they are at an early stage still. OST companies are here to stay and 
may disrupt the traditional telecommunications industry. Traditional telecommunications companies either fight against the trend and are driven out of the main stream market, or use strategies proposed by researchers to efficiently address the threats posed by open source telecommunications companies.

\subsection{Limitations}

The first limitation is that all companies in the sample are young and small. Data for a long period is not available.

The second limitation is that no suitable database is available on OST companies. The author built the database used in this research from scratch. Any omission or errors may affect the results of the thesis.

The third limitation of this research is that all the data was collected from secondary sources. Primary data may help to enrich our understanding of OST companies.

\subsection{Suggestions for future research}

Several research opportunities arose during this research. The author noticed there is considerable suspicion that a business and an OSS project may be mutually beneficial to each other ${ }^{31}$. Will an OSS project benefit from the

\footnotetext{
${ }^{31}$ Nagios creator resists too much commercialization on the OSS. Asterisk was forked after community felt too much commercialization from Digium. The OSS community was upset when Tenable released new
} 
commercialization of the OSS? Further study is needed on how to manage the relationship between a business and an OSS project, and how to arrive at a subtle balance between the OSS and the company's commercial offerings.

The second research opportunity is related to capital suppliers and the value of the OSS community. The author noticed that the majority of the companies in the sample had secured VC investment, and that an OSS community was bought by a company. Why are VCs interested in OST? What are the values they seek? What types of VCs are more likely interested in OST companies? What is the value of an OSS community to a company? How to evaluate the value of an OSS community? This set of research questions are worth further study.

A third suggestion for future research focuses on the patents filed by OST companies. Interesting research questions include: (i) Why do OST companies file for patent protection? (ii) What area do they wish to protect? and (iii) What is the relationship between the protected IP and the OSS?

software as closed-source software. There's upset among the OSS community when Sourcefire announced its acquisition by Check Point. 


\section{REFERENCES}

Bezroukov, N. 1999. OSS Development as a Special Type of Academic Research (Critique of Vulgar Raymondism). First Monday. October. http://www.firstmonday.org/issues/issue4 10/bezroukov/\#b4 (Accessed 21 March 2007)

Bonaccorsi, A. and C. Rossi. 2003. Why OSS can Succeed. Research Policy, 32(7): $1243-1258$

Bonaccorsi, A. and C. Rossi. 2004. Altruistic Individuals, Selfish Firms? The Structure of Motivations in OSS. First Monday. January.

http://firstmonday.org/issues/issue9 1/bonaccorsi/index.html (Accessed 22 March 2007)

Bonaccorsi, A., C. Rossi, S. Gianangeli. 2004. Adaptive Entry Strategies under Dominant Standards - Hybrid Business Models in the OSS Industry. http://papers.ssrn.com/sol3/papers.cfm?abstract id=519842 (Access 22 March 2007)

Brown, S. L., K. M. Eisenhardt. 1995. Product Development: Past Research, Present Findings, and Future Directions. Academy of Management Science. 20(2): $343-378$ 
Cable, D. M., S. Shane. 1997. A Prisoner's Dilemma Approach to EntrepreneurVenture Capitalist Relationships. Academy of Management Review. 22: 142-176

Carbone, P. 2007. Competing Open Source. Open Source Business Resource. July. http://www.osbr.ca/news/OSBR July07.pdf (Accessed 26 August 2007)

Chakravorti, B. 2003. The Slow Pace of Fast Change. Boston, Massachusetts. Harvard Business School Press

Chesbrough, H. W. 2000. Designing Corporate Ventures in the Shadow of Private Venture Capital. California Management Review. 42(3): 31-48

Chesbrough, H. W. 2002. Make Sense of Corporate Venture Capital. Harvard Business Review. March: 90-99

Christensen, C. M. 2003. The Innovator's Solution. Boston, Massachusetts. Harvard Business School Press

Christensen, C. M. 2004. Seeing What's Next. Boston, Massachusetts. Harvard Business School Press

Christensen, C. M. 2006. The Ongoing Process of Building a Theory of Disruption. Journal of Product Innovation Management. 23: 39-55 
Croswton, K. and J. Howison. 2005. The Social Structure of Free and OSS Development. First Monday. February.

http://firstmonday.org/issues/issue10 2/crowston/index.html (Accessed 21 March 2007)

Dahlander, L. and M. Magnusson. 2005. Relationship between OSS companies and communities: Observation from Nordic companies. Research Policy. 34: $481-493$

Eisenhardt, K. 1989. Building Theories from Case Study Research. Academy of Management Review. 14(4): 532-550

Eisenhardt, K., B. Tabrizi. 1995. Accelerating Adaptive Processes: Product Innovation in the Global Computer Industry. Administrative Science Quarterly. 40: $84-110$

Foster, R. N. 196. Innovation: The Attacker's Advantage. New York. Summit Books, Simon and Schuster

Gawer, A., M. A. Cusumano. 2002. Platform Leadership. Boston, Massachusetts. Harvard Business School Press 
Gilbert C., J. L. Bower. 2002. Disruptive Change When Trying Harder Is Part of the Problem. Harvard Business Review. May: 95-101

Gompers, P., J. Lerner. 2001. The Venture Capital Revolution. Journal of Economic Perspecitves. 15:145-168

Hawkins, R. 2004. The Economics of the OSS for a Competitive Firm. Netnomics. 6: 103-117

Hellmann, T., M. Puri. 2002. Venture Capital and the Professionalization of StartUp Firms: Empirical Evidence. The Journal of Finance. 1:169-197

lansiti, M., R. Levien. 2004. The Keystone Advantage. Boston, Massachusetts. Harvard Business School Press

Koenig, J. (2004), Seven open source business strategies for competitive advantage.

http://management.itmanagersjournal.com/article.pl?sid=04/05/10/2052216 (accessed 21 March 2007)

Krishnamurthy, S. 2002. Cave or Community? An Empirical Examination of 100 Mature Open Source Projects. First Monday. June. 
http://firstmonday.org/issues/issue7 6/krishnamurthy/index.html (Access 21 March 2007)

Lerner, J., J. Tirole. 2002. The Scope of Open Source Licensing. http://opensource.mit.edu/papers/lernertirole2.pdf (Access 22 March 2007)

Levesque, M. 2004. Fundamental Issues With OSS Development. First Monday. April. http://www.firstmonday.org/issues/issue9 4/levesque/index.html (Accessed 21 March 2007)

Lin, Y. 2005. The Future of Sociology of FLOSS. First Monday. October. http://www.firstmonday.org/issues/special10 10/lin/index.html (Accessed 21 March 2007)

Magretta, J. 2002. Why Business Models Matter? Harvard Business Review. 80(5): $86-92$

Moore, G. A. 2002. Crossing the Chasm. New York. Harper-Collins Publishers Inc

Moore, G. A. 2004. Darwin and the Demon: Innovating Within Established Enterprises. Harvard Business Review. Jul-Aug. 82: 86-92 
Pearson, H. 2000. Open Source: The Death of Proprietary Systems? Computer Law and Security Report. 16(3): 151-156

Raymond, E. S. 1998. The Cathedral and The Bazaar. First Monday. http://www. firstmonday.org/issues/issue3 3/raymond/ (Accessed 21 March 2007)

Rind, K. W. 1981. The Role of Venture Capital in Corporate Development.

Strategic Management Journal. 2: $169-180$

Rossi, C., A. Bonaccorsi. 2005. Intrinsic vs. Extrinsic Incentives in Profit-Oriented Firms Supplying Open Source Products And Services. First Monday. May. http://firstmonday.org/issues/issue10 5/rossi/index.htm|\#author (Access 21 March 2007)

Rullani, F. 2006. Dragging Developers Towards the Core: How the Free/Libre/OSS Community Enhances Developers' Contribution. http://opensource.mit.edu/papers/rullani comsocenv v5.pdf (Accessed 22 March 2007)

Tushman, M. L., P. Anderson. 1986. Technological Discontinuities and Organizational Environments. Administrative Science Quarterly. 31: 439-465 
Utterback, J. M. 1996. Mastering the Dynamics of Innovation. Boston, Massachusetts. Harvard Business School Press

Van de Ven, A. H. 1986. Central Problems in the Management of Innovation. Management Science. 32(5): 589-607

Watson, R. T., D. Wynn, M. Boudreau. 2005. JBoss: The Evolution of Professional OSS. MIS Quarterly Executive. 4(3): 329-341

Wu, R. Business models used by OSS companies.

http://h20325.www2.hp.com/blogs/wu/archive/2005/09/21/287.html (Accessed 22 March 2007)

Zider, B. 1998. How Venture Capital Works. Harvard Business Review.

November-December: 131-139 

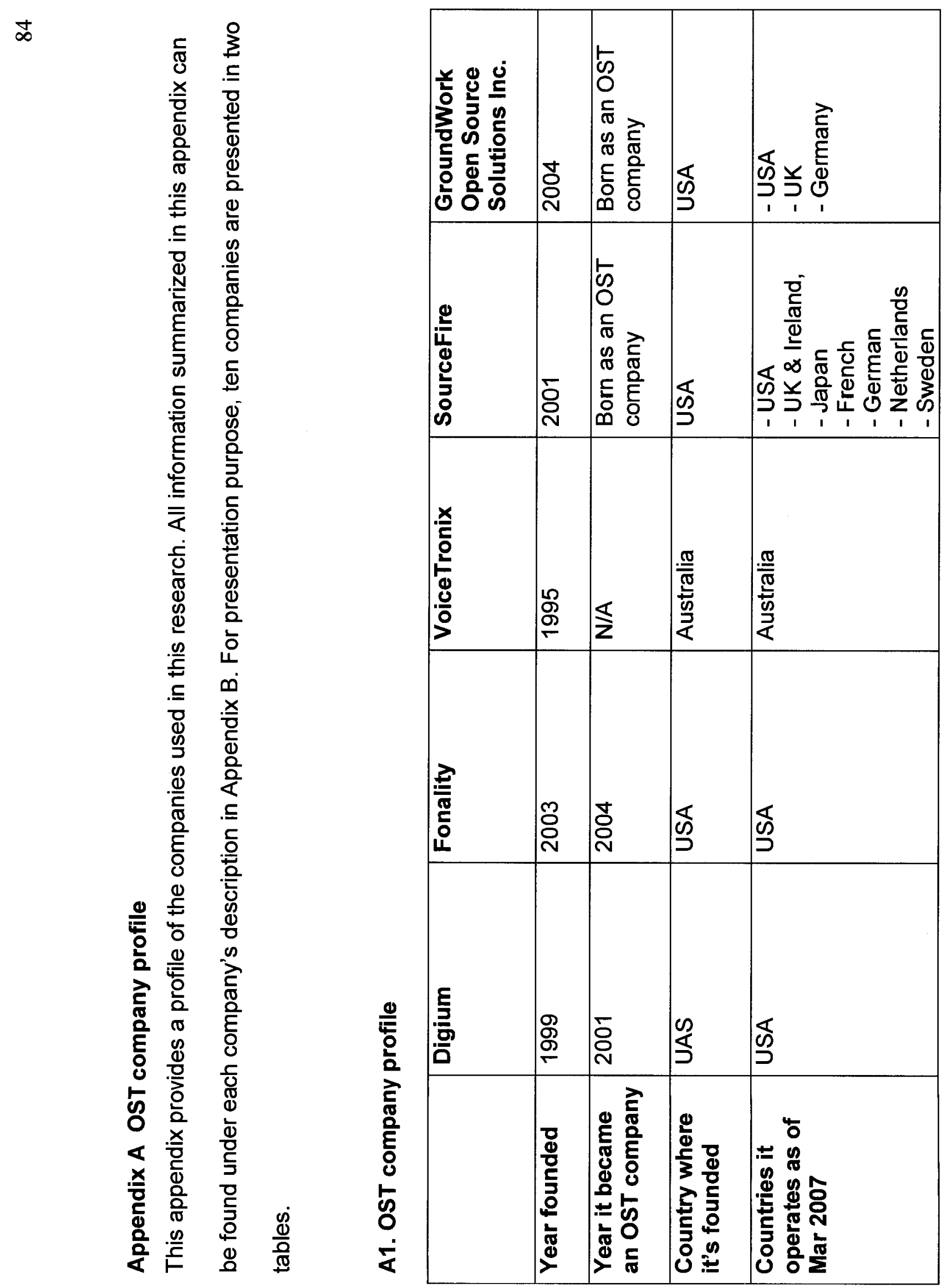


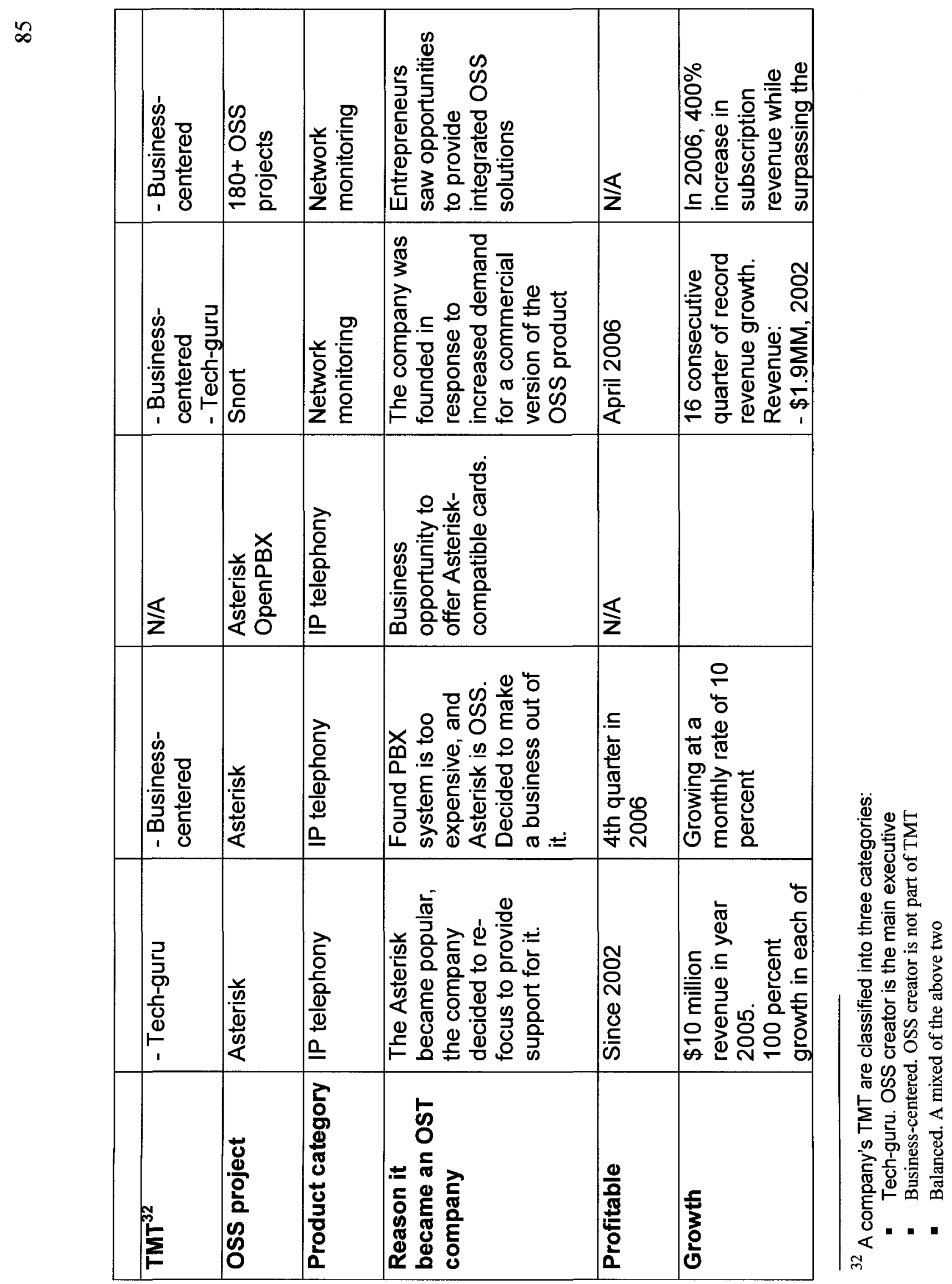




\begin{tabular}{|c|c|c|c|c|c|}
\hline 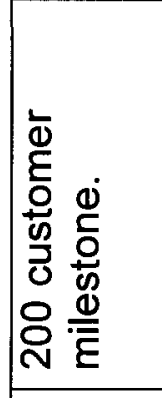 & $\mathbf{\Sigma}$ & 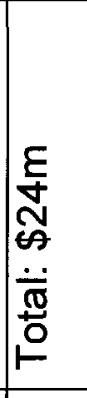 & 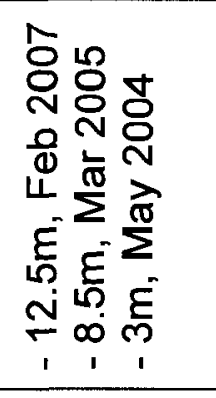 & 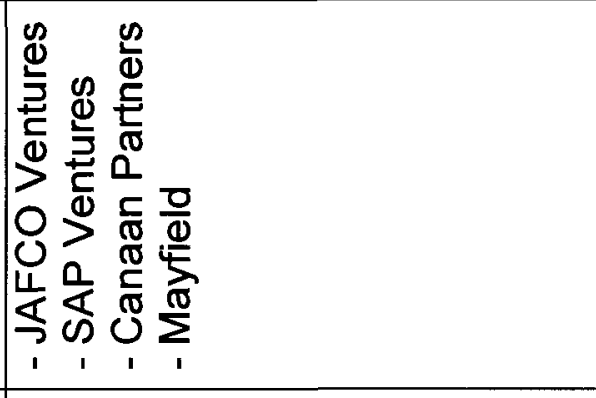 & 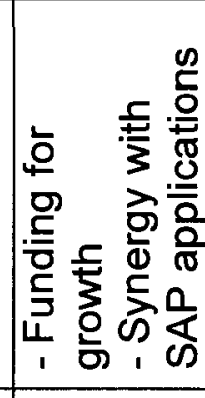 \\
\hline 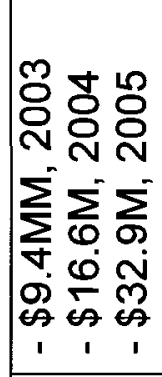 & 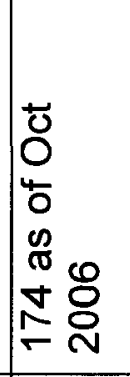 & 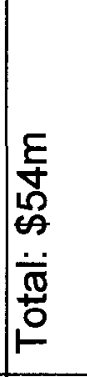 & 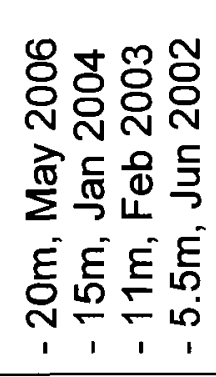 & 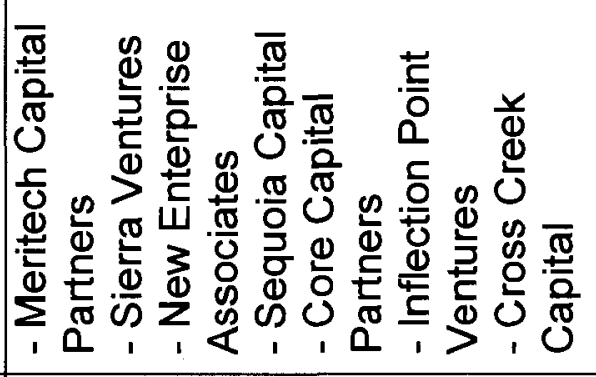 & 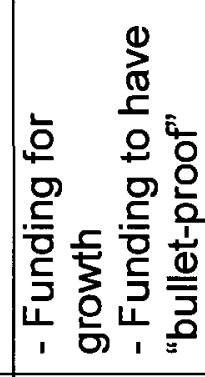 \\
\hline & $\mathbf{\Sigma}$ & 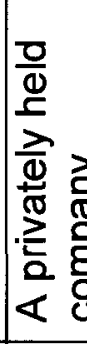 & & $\underline{\mathbf{z}}$ & 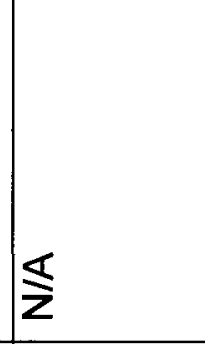 \\
\hline & 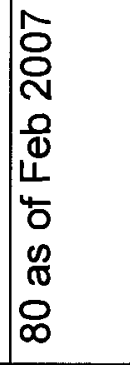 & 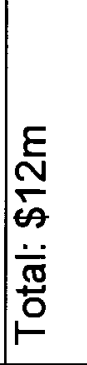 & 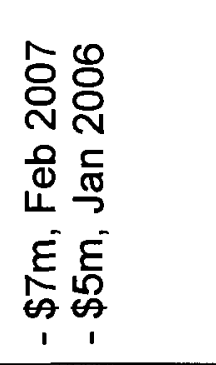 & 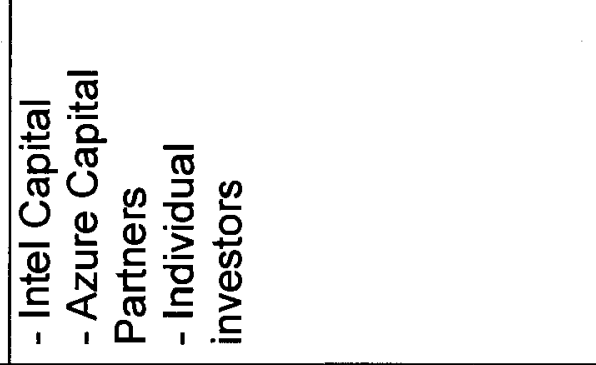 & 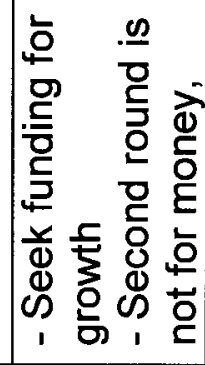 \\
\hline 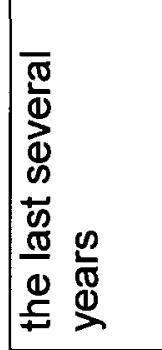 & $\frac{\$}{z}$ & 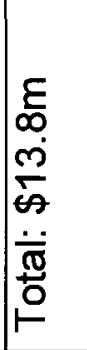 & 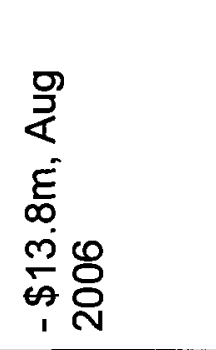 & 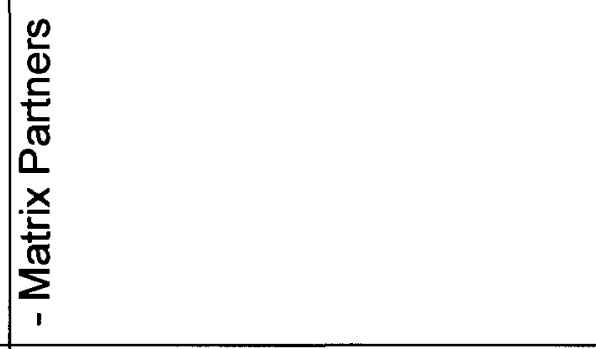 & 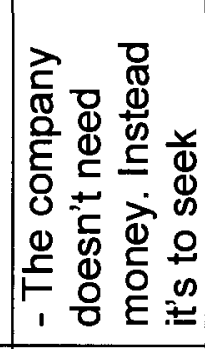 \\
\hline & 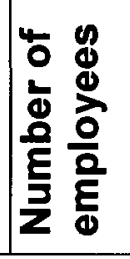 & 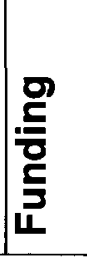 & & 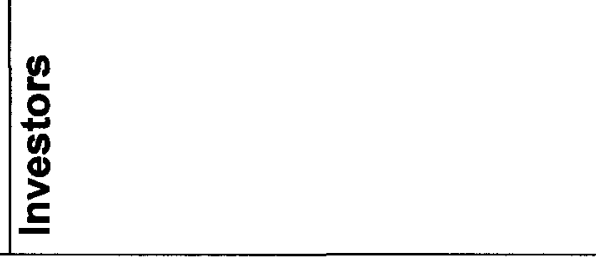 & 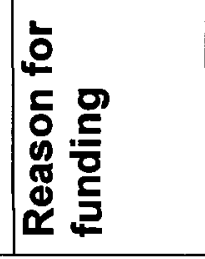 \\
\hline
\end{tabular}



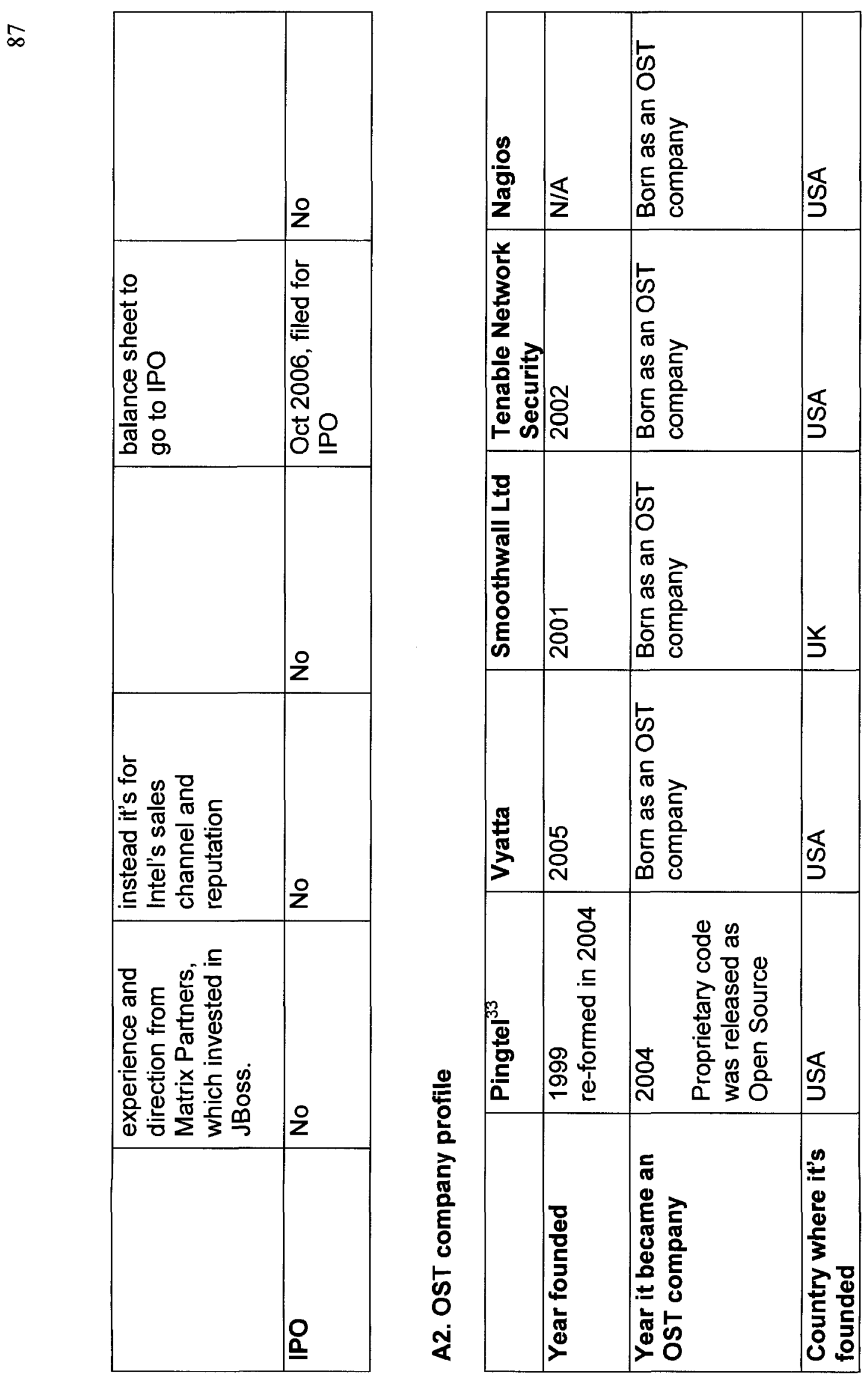

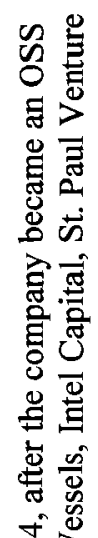

苍全司

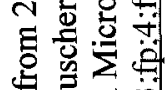

홍 중

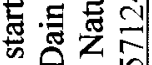

흘 氨

$\Xi g$ व

里舟

远恶

氙芯产

言응

을 豆

$=\pi$ 至웅

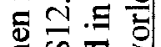

舟焉

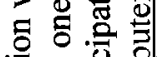

불을 형

포웅웅

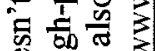

응

.․ㅡㅇ

空兽遂

要

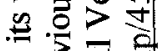

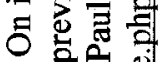

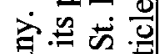

高

范芯总

흘율

氙苛总

文氞

氞言

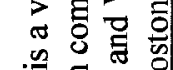

.

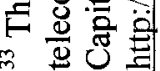




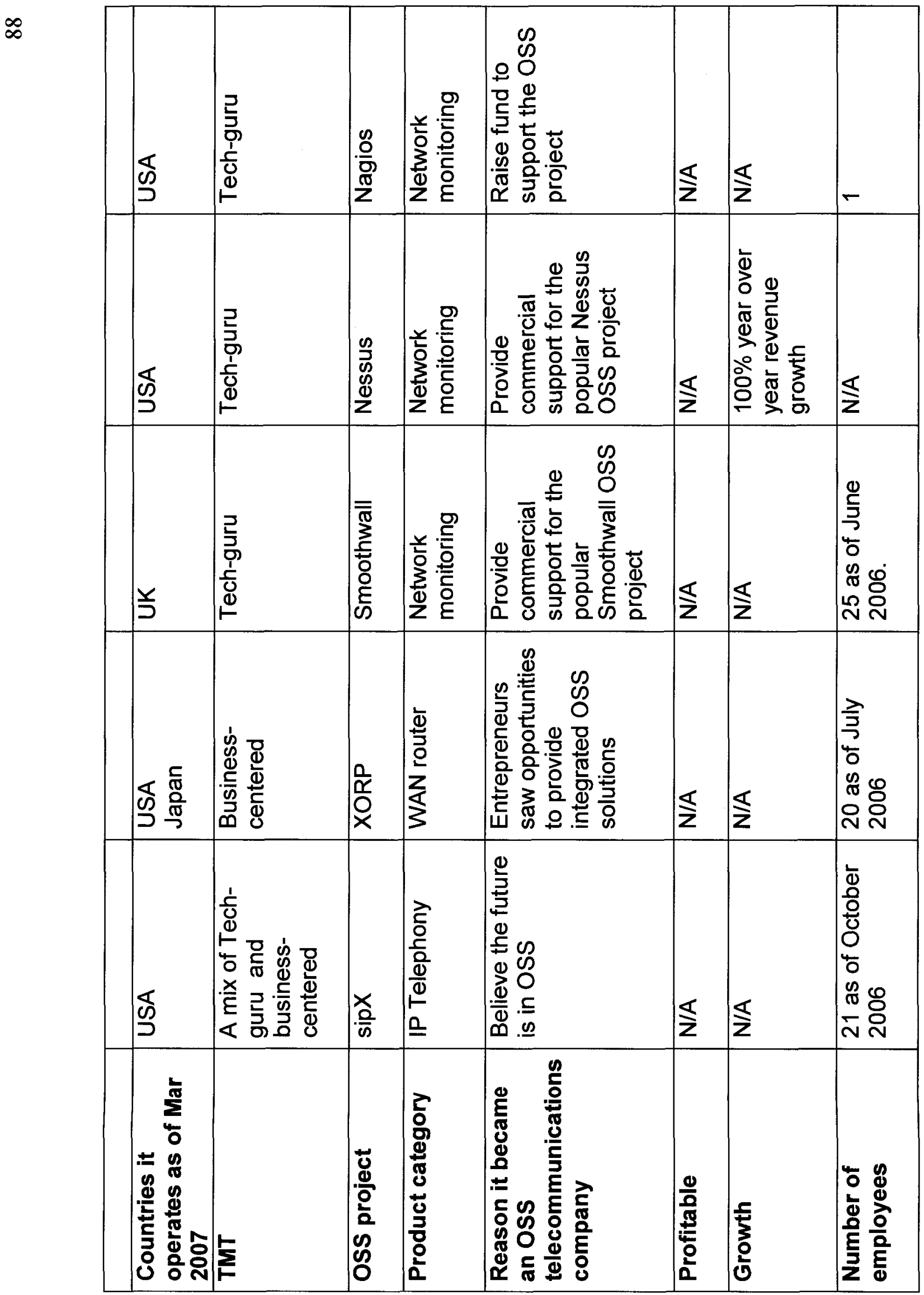



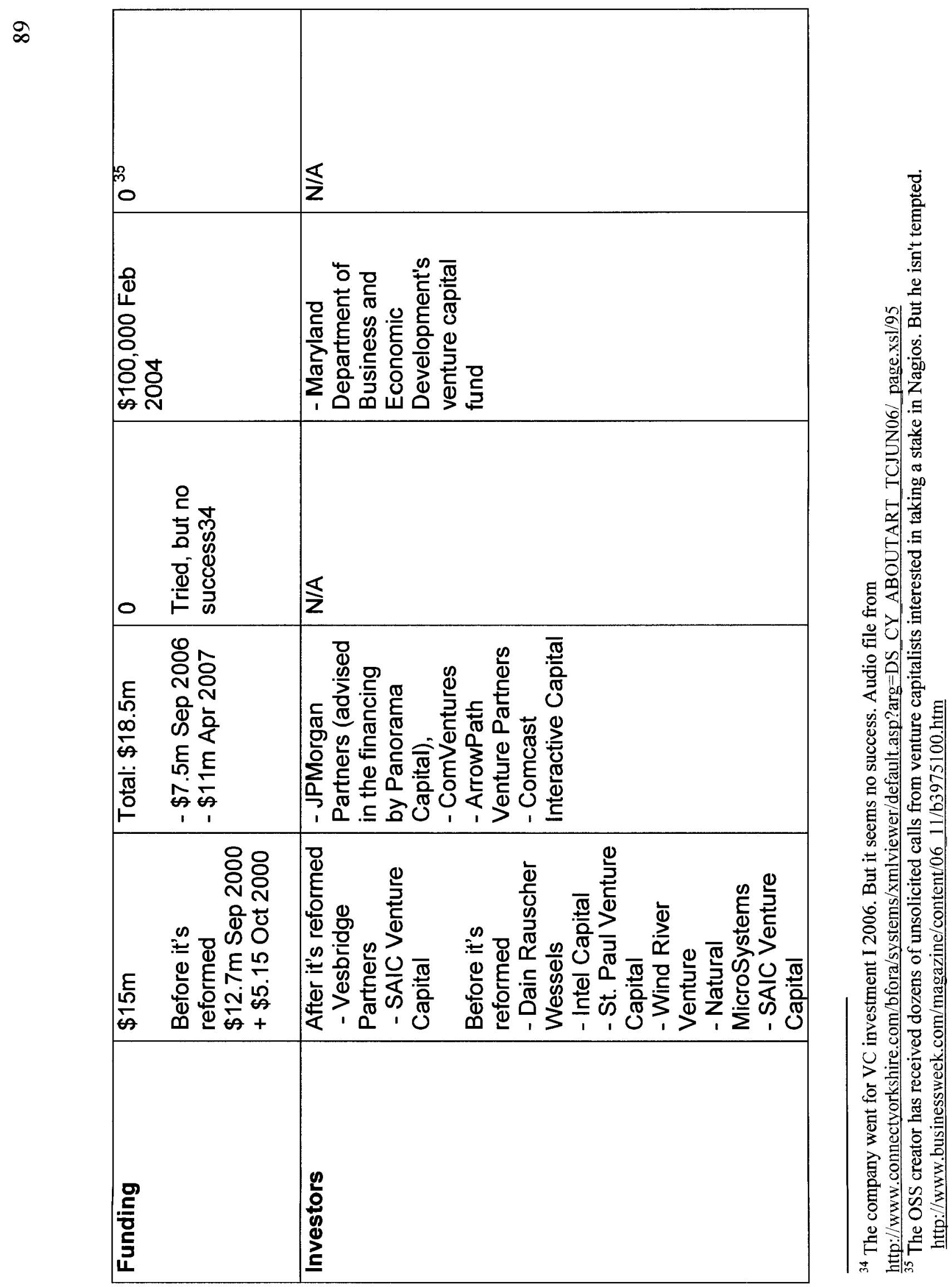
8

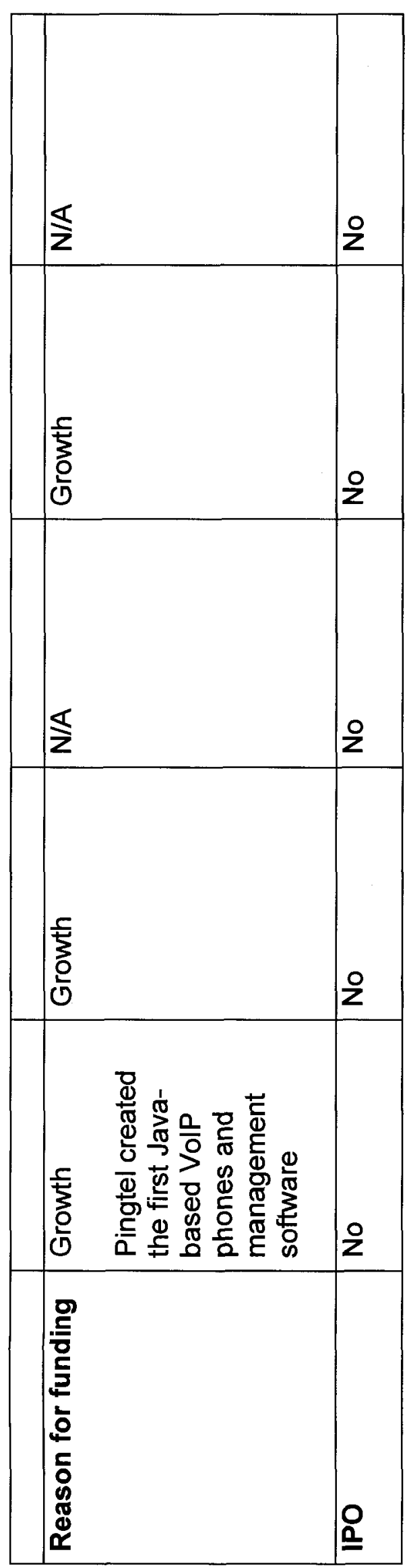




\section{Appendix B OST company write-ups}

\section{B.1 Digium Inc.}

1. Company

- Mark Spencer founded Linux Support Services in 1999. Because Mark did not have the resources to purchase a PBX for his new company, he decided to begin writing one from scratch. In 2001, Mark decided to shift the company's focus to its fledgling open-source PBX product, Asterisk ${ }^{36,}$ 37. The creator of Asterisk has been the head of the company since its inception till two telecommunications veteran executives were brought in by VC investors in January $2007^{38,39}$

- The company raised $\$ 13.8 \mathrm{~m}$ VC investment from Matrix Partners in August 2006. It has been profitable since 2002, and has experienced 100 percent growth in each of the last several years. Asterisk has over one million users and it has 130 Genuine Asterisk solutions partners worldwide. What the company is after from the VC investment is for experience and direction. Mark Spencer said, "Matrix's experience as a JBoss initial investor was a key differentiator. Early on, we realized Matrix's involvement would help us grow more quickly" $40,41,42$

- Digium filed for patent on its VoiceBus ${ }^{\mathrm{TM}}$ architecture $^{43}$

\footnotetext{
${ }^{36} \mathrm{http}: / /$ www.digium.com/en/company/profile/history.php

${ }_{38}^{37} \mathrm{http://en.wikipedia.org/wiki/Digium}$

http://www.asteriskvoipnews.com/asterisk development/adtran execs defect to digium plan channel p ush.html

${ }^{39} \mathrm{http}: / /$ www.digium.com/en/mediacenter/news/viewpress.php?id=digium CEO

${ }^{40} \mathrm{http}: / /$ www.tmenet.com/news/2006/08/09/1781562.htm

41 http://news.com.com/Is +the+telephone+industry +ready + for + open + source/2008-1082 3-5737703.html

$42 \mathrm{http}: / /$ www.tmenet.com/news/2006/08/09/1781562.htm

${ }^{43} \mathrm{http}: / / \mathrm{www}$. digium.com/en/mediacenter/news/viewpress.php?id=TDM2400P
} 
2. Revenue sources ${ }^{44,45,46}$

- Hardware: Asterisk appliance developer kit, voice processing card $(\text { TC400B) })^{47}$, digital interface card (B410P, TE412P, TE410P, TE407P, TE405P, TE212P, TE210P, TE207P, TE205P, TE120P) ${ }^{48}$, analog phone devices (TDM2400P, TDM800P, TDM400P) ${ }^{49}$, G.729 Codec, IVR prompt.

- Software: Asterisk business edition, echo cancellation, speech engine

- Licensing: Asterisk, libpri, libIAX, G.297 $\operatorname{codec}^{50}$

- Service: customer service (Configuration Package, Customer Development) ${ }^{51}$, consulting (Digium's Consulting Services) ${ }^{52}$, support service $\left(5 \times 8 \times\right.$ NBD Maintenance Plan, $7 \times 24 \times$ NBD Maintenance Plan) ${ }^{53}$

- Training: courses, certification

3. Ecosystem

- Digium to the open source IP telephony market is like IBM to the Personal Computer market. IBM's open interface and modular architecture in its PC design resulted in IBM-compatible PCs which are competing products to IBM's PC. The open source telephony started with Asterisk, and now many companies offer Asterisk-compatible cards, which are competing products to Digium's offering

\footnotetext{
${ }^{44} \mathrm{http}: / /$ www.digium.com/en/products/

45 http://www.digium.com/en/services/

${ }^{46} \mathrm{http} / / / \mathrm{www}$. digium.com/en/training/

${ }^{47} \mathrm{http} / / / \mathrm{www}$. digium.com/en/products/hardware/voicecards.php

${ }^{48} \mathrm{http} / / / \mathrm{www} \cdot$ digium.com/en/products/hardware/digitalcards.php

${ }^{49}$ http://www.digium.com/en/products/hardware/analogcards.php

${ }^{50} \mathrm{http}: / / \mathrm{www}$.digium.com/en/products/software/licensing.php

51 http://www.digium.com/en/services/custom/

$52 \mathrm{http} / / \mathrm{www}$.digium.com/en/services/consulting/

${ }^{53}$ http://www.digium.com/en/services/support/maintenance.php
} 
- The company has partners to provide commercial offerings to its customer $^{54}$. The OSS community that the company supports is Asterisk community

4. Benefits and risks

- It's very hard to control OSS community and the OSS creator is not necessarily the most successful company that commercializes the OSS.

The world's largest Asterisk-based commercial Asterisk deployment is a 2year startup Fonality, not Digium, the original Asterisk developer ${ }^{55}$

- Asterisk-based IP telephony will move ahead, even if its creator is not. ${ }^{56}$ Trixbox was based on Asterisk, and is the world's largest Asterisk-based community. It was bought by Fonality ${ }^{57}$

- Too much control from Digium over Asterisk resulted in a fork of the OSS project. OpenPBX was forked from Asterisk $1.2^{58,59}$

- As creator and owner of the popular Asterisk, Digium is the thought leader in its industry

5. Relationship between commercial offerings and the OSS project

\footnotetext{
${ }^{54}$ The company divides its commercial partners into three communities: solution community, service community, and second layer community.

${ }^{55}$ When we talk about open source bringing vendor independence and empowering customers to be in control of their own industry, it does mean we have our work cut out for us. The industry will be much larger than we are, and there will probably be companies selling more significant products. We can't sit back. If we didn't play our cards right, then the Asterisk wave could go on and we'd not be part of it as much as we'd like to.http://www.vonmag.com/webexclusives/2006/08/21_Fonality Claims Crown.asp ${ }_{56}^{56} \mathrm{http}: / /$ news.com.com/Is+the + telephone+industry + ready + for + open + source/2008-1082 3-5737703.html

${ }^{57} \mathrm{http://www.trixbox.org/}$

58 http://wiki.openpbx.org/tiki-index.php?page=Statement

59 http://www. voip-info.org/wiki/index.php?page=OpenPBX.org
} 
- A business edition is the same software put through more formalized testing, sold with a more traditional software license model. When we develop new software, we do make it available ${ }^{60}$

\section{B.2 Pingtel}

\section{Company ${ }^{61}$}

- The company was a proprietary product supplier till February 2004 when it released its product platform source code into open source. It also sold its phone line business to focus solely on software ${ }^{62}$. Pingtel's business model is based on delivering the requisite service and support for an enterprise-grade edition of the open source-based source code ${ }^{63}$

- TMT is stable since the company became an OST company in 2004 , with addition of two executives in sales and support ${ }^{64}$. Amazon.com and Earthlink are Pingtel's customers ${ }^{65,66}$

- Pingtel has filed two patents for its architecture and method ${ }^{67}$

\section{Revenue sources}

- PBX Appliance. SIPxchange ECS 50 is a commodity PC from Gateway that has pre-installed SIPxchange ECS software ${ }^{68}$

\footnotetext{
${ }^{60} \mathrm{http} / / /$ news.com.com/Is + the + telephone + industry + ready + for + open + source/2008-1082 3-5737703.html ${ }^{61}$ The company was founded in 1999, and created the world's first java-base VoIP phone. It had world class investors include Intel Capital, Wind River Capital. But it seems that the company did not take off with that business. And in year 2004, the company re-birthed itself as an OSS telecom company.

${ }^{62} \mathrm{http}$ ://www.pingtel.com/upload/library/corporatefaq.pdf

${ }^{63} \mathrm{http://www.pingtel.com/page.php?id=31}$

${ }^{64} \mathrm{http}: / /$ www.pingtel.com/company/pdfs/PintelExpandsExecutiveTeam.pdf

${ }^{65} \mathrm{http}: / / \mathrm{www}$. vonmag.com/webexclusives/2006/10/9 Pingtel wins ainazon.asp

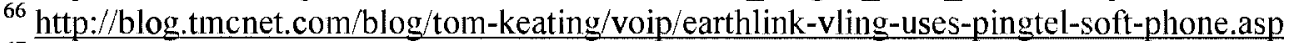

${ }^{67} \mathrm{http} / /$ gauss.ffii.org/Search/All/Applicant/Pingtel\%20corp

${ }^{68}$ http://www.pingtel.com/page.php?\&id=169
} 
- Software: Toll quality support feature is available only in commercial offering $^{69}$

- Service: subscription programs (Jump Start program, Technical Assistance Center (TAC) Support, Specialized TAC support) ${ }^{70}$, consulting (Application Support, Consulting ${ }^{71}$, technical assistance, interoperability testing, training programs, custom documentation, etc ${ }^{72}$

3. Ecosystem ${ }^{73}$

- The company's commercial partners includes: phone partners, media gateway partners, application partners ${ }^{74}$

- The company's OSS community is SipFoundry

4. Benefits and risks

- A world-wide community (developers from 64 countries) was formed, and enabled the company quickly become a world-wide player ${ }^{75}$

- The company also pursues opportunity to dramatically increase its market share of the IP PBX market by becoming an OST company ${ }^{76}$

5. Relationship between commercial offerings and the OSS project The OSS version doesn't have toll-quality codec and the documentation is incomplete ${ }^{77}$

\footnotetext{
${ }^{69} \mathrm{http}: / /$ www.pingtel.com/page.php?id=133

${ }^{70} \mathrm{http:} / / \mathrm{www}$.pingtel.com/page.php?id=95

${ }^{71}$ http://www.pingtel.com/page.php? id $=49$

${ }_{72}$ http://www.pingtel.com/page.php?id=13

${ }^{73} \mathrm{http}: / /$ www.pingtel.com/page.php?id=83

${ }^{74}$ Phone partners: Polycom, Inc., Grandstream Networks, Inc, etc. Media gateway partners: AudioCodes Ltd., VegaStream, etc. Application partners: Jasomi Networks, Citel Technologies, etc. Others: Check Point Software Technologies, Ingate Systems, etc.

75 http://www.pingtel.com/page.php?id=133

${ }^{76} \underline{\text { http: }: / \text { www.pingtel.com/upload/library/corporatefaq.pdf }}$
} 


\section{B.3 Fonality}

\section{Company}

- The company was founded in 2003 , and it bought a one-year old Asteriskbased company in the same year ${ }^{78,79}$, Founders are experienced start-up creators. TMT also includes experienced members from public-traded companies $^{80}$

- The company has raised $\$ 12 m$ from VC investment, In February 2007 , $\$ 7 \mathrm{~m}$ investment was led by Intel Capital ${ }^{81}$, and in January $2006, \$ 5 \mathrm{~m}$ investment was made by Azure Capital Partners with participation from individual investors ${ }^{82}$

- The company grows at a monthly rate of 10 percent, and turned a profit in the fourth quarter of 2006. It serves more than 1,600 businesses in 25 countries $^{83,84,85}$

- Fonality filed patent for architecture used in PBXtra ${ }^{86,87}$

2. Revenue sources ${ }^{88}$

${ }^{77}$ http://www.pingtel.com/page.php?id=133

${ }^{78} \mathrm{http}: / /$ www.fonality.com/press.html

${ }^{79} \mathrm{http}: / / \mathrm{www}$. fonality.com/about us.html

${ }^{80} \mathrm{http} / / \mathrm{www}$. fonality.com/management.html

${ }^{81} \mathrm{http://money.cnn.com/2007/02/07/technology/bc.opensource.telecoms.reut/index.htm}$

${ }_{82}^{8 h} \mathrm{http} / /$ www.voip-news.com/news/fonality-capital/

$83 \mathrm{http://www.fonality.com/press}$

${ }^{84} \mathrm{http}: / /$ money.cnn.com/2007/02/07/technology/bc.opensource.telecoms.reut/index.htm

85 July 13, 2005, customers have put 4million calls. January 30,2006 , customers have put 10 million calls. May 15, 2006, customers have put 20 million calls. August 10, 2006, customers have put 30 million calls. November 28, 2006, customers have put 50million calls.

${ }^{86} \mathrm{http}: / /$ www. fonality.com/press.html

${ }_{88}^{87}$ http://saunderslog.com/tag/Fonality

${ }^{88} \mathrm{http}: / /$ www.fonality.com/q.cgi 
- Appliance: Software is pre-installed on commodity hardware from HP (PBXtra Standard, PBXtra Professional) ${ }^{89}$

- Service: annual software maintenance fee is charged (1-4 phones, \$65/user/year; 5-10 phones, \$60/user/year; $11-20$ phones, $\$ 58 /$ user/year; 21-40 phones, \$56/user/year; 41-80 phones, \$52/user/year; 81-200 phones, \$48/user/year; 201-500 phones, \$42/user/year; 501-1000+ phones, $\$ 38 /$ user/year) ${ }^{90}$

3. Ecosystem

- The company uses traditional business model. Not like other open source IP PBX providers, the customers must buy phones from Fonality as well ${ }^{91}$

- It bought TrixBox, the world's largest Asterisk-based community, in October $2006^{92}$. An Asterisk guru, Kerry Garrison, joint Fonality and is in charge of trixbox application and community infrastructure ${ }^{93}$

4. Benefits and risks

- The company has achieved fast time to market, low cost, and reliability by using Asterisk as its product's basis

- The company released its product one year after it was founded ${ }^{94}$.

- A 30-user phone PBX, or switchboard, runs around $\$ 7,500$ to $\$ 10,000$ from Fonality, about 50 percent less than Cisco's rival products and 40 percent below Avaya ${ }^{95}$. The company has hardened the Asterisk code ${ }^{96,97}$

\footnotetext{
${ }^{89} \mathrm{http}: / / \mathrm{www}$. fonality.com/pbxtra pricing.cgi

${ }_{90}$ http://www. fonality.com/customer support.html

$91 \mathrm{http://www.fonality.com/faq.html}$

${ }_{92} \mathrm{http} / /$ blog.tmcnet.com/blog/tom-keating/asterisk/fonality-acquires-trixbox.asp

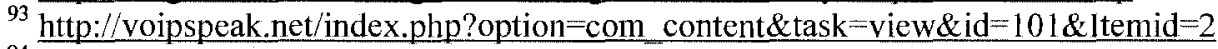

${ }^{94}$ http://blog.tmenet.com/blog/tom-keating/asterisk/fonality-pbxtra-the-worlds-largest-commercial-asteriskdeployment.asp
} 
5. Relationship between commercial offerings and the OSS project No data was found.

\section{B.4 VoiceTronix}

1. Company

- Founded in 1995, and has been selling its own line of CT (Computer Telephone) cards since 1998. It's a privately owned and located in Australia

- Its products support Asterisk and OpenPBX ${ }^{98}$

2. Revenue source

- Hardware: Asterisk-compatible CT cards (OpenPCl-4L, OpenPCI-8L, OpenPCl-8LS, OpenLine4, OpenSwitch12, OpenLog, OpenPri). ${ }^{99}$ To a degree, VoiceTronix's product to Digium's product is like IBM-compatible PCs to IBM PC. Its products support Asterisk and OpenPBX, a fork from Asterisk

3. Ecosystem

- The company has distributors in USA, Canada, Japan, Singapore. They are telephonyware, OpenCom Inc., Ntegrator, DB Streams, etc ${ }^{100}$

- The company participates in OpenPBX, VPB Driver, Bayonne, Asterisk, OpenH323 PSTNGW Logger, CT Server, YCTA server, Speex ${ }^{101}$

\footnotetext{
${ }^{95} \mathrm{http}: / /$ money.cnn.com/2007/02/07/technology/bc.opensource.telecoms.reut/index.htm

${ }^{96} \mathrm{http}: / /$ gigaom.com/2006/08/18/fonality-asterisks-best-buddy/

${ }^{97}$ http://www. fonality.com/about us.html

$98 \mathrm{http://www.voicetronix.com.au/products.htın}$

${ }^{99} \mathrm{http}: / /$ www.voicetronix.com/products.htm

${ }^{100} \mathrm{http} / / / \mathrm{www}$.voicetronix.com.au/purchasing.htm

101 http://www.voicetronix.com/open-source.htm
} 
4. Benefits and risks

Open source telephony companies tend to focus on software, e.g., Pingtel sold its phone business in $2004^{102}$. But a phone system has to have some basic hardware. There is a unique opportunity to be a lead open source card manufacture. Hardware companies routinely give away software to sell hardware, e.g. Intel gives away developer kit for free. Using OSS, VoiceTronix achieved the same purpose.

5. Relationship between commercial offerings and the OSS project The company is a hardware supplier. Its commercial offerings are hardware complementary to Asterisk and OpenPBX.

\section{B.5 Sourcefire}

1. Company

- The company was founded in 2001 in response to increased demand for a commercial version of the popular OSS, Snort OSS ${ }^{103}$. The OSS project creator has been founder and СTO of the company

- Filled for IPO in October, 2006 to raise up to $\$ 75 \mathrm{~m}$. The company has raised more than $\$ 54 \mathrm{~m}$ in VC investment. And it was about to be acquired by Check Point in October 2005, an Israel-based internet and VPN security provider, for $\$ 225$ million. Check Point withdrew from the deal after the Committee on Foreign Investment in the United States voiced

\footnotetext{
${ }^{102} \mathrm{http} / /$ www.pingtel.com/upload/library/corporatefaq.pdf

${ }^{103} \mathrm{http} / / \mathrm{ww} w$. sourcefire.com/products/downloads/public/sf backgrounder.pdf? $\mathrm{a}=1 \& \mathrm{~b}=2 \# \mathrm{go}$
} 
objections over a foreign company owning Sourcefire, whose technology secures some U.S. government networks ${ }^{104,105,106,107,108,109}$

- All 100 of Fortune 100 are Sourcefire's customers ${ }^{110}$

- The company is cash-flow positive in April 2006 and it has 16 consecutive quarter of record revenue growth ${ }^{111}$. Revenue ramp starting in 2002:

$\$ 1.9 m, \$ 9.4 m, \$ 16.6 m, \$ 32.9 m^{112,113 .}$ As of October 2006 , the company has 174 employees $^{114}$

- The company has filed patent for combination of threat and network discovery, behavioral profiling, and integrated vulnerability management ${ }^{115}$

2. Revenue source

- The company uses the Internet to distribute open-source software for free and selling proprietary (Sourcefire Intrusion Agent for Snort) ${ }^{116}$ pieces that enhance the free stuff ${ }^{117}$

- Service: Three levels of services available $e^{118}$

\section{Ecosystem}

- The company's commercial partners include: IBM, Nortel, Sun

Microsystems Inc, Symantec, etc ${ }^{119}$

\footnotetext{
${ }^{104} \mathrm{http}: / / \mathrm{www}$. sourcefire.com/products/downloads/public/sf backgrounder.pdf? $\mathrm{a}=1 \& \mathrm{~b}=2 \mathrm{\# gO}$

105 http://www.scmagazine.com/us/news/article/549646/

${ }_{106} \mathrm{http://www.scmagazine.com/uk/news/article/601467/sourcefire-going-public/}$

$107 \mathrm{http}: / \mathrm{www}$.bizjournals.com/washington/stories/2006/04/03/story3.html

${ }_{108} \mathrm{http}: / / \mathrm{www} . \mathrm{sec} . g 0 v / A r c h i v e s /$ edgar/data/1168195/000095013306004558/w24360svl.htm

$109 \mathrm{http}: / /$ www. securityfocus.com/news/11382

$110 \mathrm{http}: / / \mathrm{www}$. sourcefire.com/products/downloads/public/sf backgrounder.pdf? $\mathrm{a}=1 \& \mathrm{~b}=2 \mathrm{\# g}$

${ }^{111} \mathrm{http}: / / \mathrm{www}$.sourcefire.com/news/press releases/pr-15.html

$112 \mathrm{http}: / /$ securityincite.com/blog/mike-rothman/ohmygod-sourcefire-to-ipo

$113 \mathrm{http}: / / \mathrm{www}$.sec.gov/Archives/edgar/data/1168195/000095013306004558/w24360svl.htm

$114 \mathrm{http} / / \mathrm{www}$.scmagazine.com/uk/news/article/601467/sourcefire-going-public/

$115 \mathrm{http://www.sourcefire.com/compliance/fisma.html}$

${ }_{116} \mathrm{http}: / / \mathrm{www}$. sourcefire.com/products/is agent.html

117 http://www.cio.com/archive/021506/opensource.html

118 http://www.sourcefire.com/services/support.html
} 
- Snort was started in 1998 by Martin Roesch. It's released under GPL ${ }^{120}$. It has been downloaded for more than 3 million times

4. Benefits and risks

The company mentioned following benefits of depending on OSS:

- Open source is an incredibly powerful way to develop software because the startup costs are low ${ }^{121}$

- In a competitive market, open source also makes it easier for you to gain mindshare ${ }^{122}$

- I've always looked at the community as a giant testing lab to make sure the software is working properly, and also as an idea generator to improve ideas that may not be working that great. Plus it's a potential user base for the other things we may develop. the networking effects and the good will from the community, if you build it properly, are worth every bit as much as the IP itself ${ }^{123}$

5. Relationship between commercial offerings and the OSS project

Paid customers get rules update immediately, and OSS gets update five days later $^{124}$

\footnotetext{
${ }^{119}$ ArcSight, Breach Security, Check Point Software Technologies, etc Crossbeam Systems, Cybertrust, IBM, Intellitactics, LURHQ, NetFroensics Inc., NetMonSecure, NetSec, Nortel, Sun Microsystems Inc, Symantec, Tivoli Risk Managemer, VeriSign.

${ }_{120} \mathrm{http}: / /$ www.snort.org/about snort/faq/faq.htm/\#4.4

$121 \mathrm{http://www.informationweek.com/news/showArticle.jhtml?articleID}=189500016$

$122 \mathrm{http://www.informationweek.com/news/showArticle.jhtml?articleID}=189500016$

${ }_{123} \mathrm{http}: / /$ searchsecurity.techtarget.com/qna/0,289202,sid14 gcil 169005,00.html

$124 \mathrm{http}: / /$ searchsecurity.techtarget.com/tip/0,289483, sid14 gcil 084769,00.htm1
} 


\section{B.6 Nagios}

1. Company

- Ethan Galstad created Natios to fund the OSS project. He works as a network administrator at the University of Minnesota in the United States.

$\mathrm{He}$ is also the president of Ayamon, LLC - a company he founded in 2003 to promote OSS $^{125}$

- Ebay, Yahoo!, Sun Microsystems are among more than 1000 organizations in the world that deployed Nagios in their network. ${ }^{126,127}$

- He purposed pursues complementary product model. He works with companies that provide solutions that complement Nagios, but don't directly compete with it. This type of partnership model isn't really mentioned in the Open Source business models ${ }^{128}$

2. Revenue source

Appliance: the company teams with azeti Networks to provide customers a "NAGIOS out-of-the-box" experience ${ }^{129}$

3. Ecosystem

- The company teams up with other suppliers to provide customers commercial solutions. Altinity, NETWAYS, Frontline, AGTech, OpServices, TruePath Technologies, Comunet Pty Ltd, op5 are the partners $^{130}$

\footnotetext{
${ }^{125} \mathrm{http}: / /$ archive.fosdem.org/2005/index/speakers/speakers galstad.html

$126 \mathrm{http}: / / \mathrm{www}$-users.itlabs.umn.edu/classes/Fall-2005/seng5899/Galstad Talk.pdf

$127 \mathrm{http}$ ://WwW.nagios.org/userprofiles/search.php?search=1

$128 \mathrm{http}: / /$ weblog.infoworld.com/openresource/archives/2006/03/ethan galstad o.html

$129 \mathrm{http}: / /$ www.nagios.org/products/nagiospowered/azeti/

130 http://www.nagios.org/solutions/
} 
- Company creator is also the OSS creator, and he owns the trade mark of Nagios. It's released under GPL license, version $2^{131}$

4. Benefits and risks

- Not enough support for end customer will prevent customer from buying ${ }^{132}$

- External feedback and suggestions would be valuable, and result would be a better product ${ }^{133}$

5. Relationship between commercial offerings and the OSS project It carefully chooses the complementary model to avoid the tension between a commercial offering and OSS project.

\section{B.7 Smoothwall}

\section{Company}

- In late 2001, Manning and Morrell, with George Lungley, formed SmoothWall Limited as a UK registered private limited company ${ }^{134}$. The OSS project creator is a key member of the company's team ${ }^{135}$

- The company tried to raise money $(750,000$ pound) in June 2006 , but it seems no success ${ }^{136}$

- It has 25 employees as of June $2006^{137}$

\footnotetext{
$131 \mathrm{http}: / /$ en.wikipedia.org/wiki/Nagios

$132 \mathrm{http}: / /$ searchnetworking.techtarget.com/originalContent/0.289142,sid7 gcil242762.00.html

$133 \mathrm{http://www-users.itlabs.umn.edu/classes/Fall-2005/seng} 5899 / \mathrm{Galstad}$ Talk.pdf

${ }^{134} \mathrm{http} / / /$ en.wikipedia.org/wiki/SmoothWall

135 http://www.smoothwall.net/company/bios.php

${ }^{136}$ Audio file from http://www.connectyorkshire.com/bfora/systems/xmlviewer/default.asp?arg=DS CY ABOUTART TCJU N06/_page.xsl $/ 95$

${ }^{137}$ Audio file from http://www.connectyorkshire.com/bfora/systems/xmlviewer/default.asp?arg=DS CY ABOUTART TCJU N06/ page.xsl/95
} 


\section{Revenue source}

- Software appliance: integrate Smoothwall with hardened OS and other OSS software; add-ons ${ }^{138,139}$

- Hardware appliance: SmoothGuard 1000-UTM is a pre-installed appliance $^{140}$

3. Ecosystem

- The company has a vast partner network: $40+$ in USA, 7 in Canada, and many in other countries ${ }^{141}$

- The company is the creator and owner of Smoothwall OSS project.

SmoothWall began in August 2000, and it released under $\mathrm{GPL}^{142,143}$

4. Benefits and risks

- Same as Asterisk OSS project, there's disagreement on the roadmap of Smoothwall OSS project, and IPCop was forked from SmoothWall GPL 0.9 .9 in late $200^{144,145}$

- The balance between OSS and commercial development is hard to achieve. People (developers) will be suspicious and jump boat when the company puts priority on commercial development over OSS development ${ }^{146}$

\footnotetext{
${ }^{138}$ http://www.smoothwall.net/support/faq/index7.php?c-\&id 4\&view-y\&search-CANADA

$139 \mathrm{http://www.smoothwall.org/about/company.html}$

$140 \mathrm{http}: / /$ www.smoothwall.net/products/smoothguard 1000/?sysreq

${ }_{141} \mathrm{http://www.smoothwall.net/partners/reseller.php}$

142 http://en.wikipedia.org/wiki/SmoothWall

143 http://en.wikipedia.org/wiki/SmoothWall\#SmoothWall GPL

${ }_{144} \mathrm{http}: / / \mathrm{www}$. securityfocus.com/infocus/1556

$145 \mathrm{http} / / /$ en.wikipedia.org/wiki/SmoothWall $\#$ SmoothWall GPL

${ }^{146} \mathrm{http} / / /$ lists.samba.org/archive/linux/2002-January/001770.html
} 
- Fast time to market. The company was founded in 2001 , and in the same year, the company was able to release its first product ${ }^{147}$

- The Project provides a fertile testing and development ground for bleeding edge features - some of which may get used by the company ${ }^{148}$

- Cheap cost. The underlining operating system and many components are OSS $^{149}$

5. Relationship between open source project and commercial offering

- The Smoothwall OSS is a basic level firewall product. The commercial offering is more sophisticated ${ }^{150}$

- Smoothwall Ltd progressively releases commercially developed features back into the GPL version ${ }^{151}$

\section{B.8 GroundWork Open Source Solutions}

1. Company

- Founded in Oakland California in 2004 , the company has offices in USA, United Kingdom, and Germany ${ }^{152}$

- The company has raised $\$ 24 \mathrm{~m}$ since its inception. $3 \mathrm{~m}$ in May $2004,8.5 \mathrm{~m}$ in March 2005, and 12.5m in Feb 2007 from SAP venture, and others $^{153,154,155}$

\footnotetext{
${ }^{147}$ Audio file from http:/www.conneclyorkshirc.com/bfora/systems/xmlviewer/dcfault.asp?arg-DS CY ABOUTART TCJU N06/page.xsl/95

148 http://www.smoothwall.org/about/faq.html

${ }_{149}$ http://www.smoothwall.net/support/faq/index5.php?c=newe\&id=4\&view=y\&typer=

${ }_{150}$ Audio file from http://www.connectyorkshire.com/bfora/systems/xmlviewer/default.asp?arg=DS CY ABOUTART TCJU N06/ page.xsl/95

${ }^{151} \mathrm{http}: / / \mathrm{www} . \mathrm{smoothwall.net/company/history.php}$

152 http://en.wikipedia.org/wiki/GroundWork Monitor Open_Source
} 
- In 2006 , GroundWork had a $400 \%$ increase in subscription revenue while surpassing the 200 customer milestone ${ }^{156}$

- Royal Bank of Canada ${ }^{157}$, Great-west life \& annuity, United States marine corps, Florida Department of State are a few of the company's customers $^{158}$

- The company melds together over 180 open source projects ${ }^{159}$. At the core, it's Nagios OSS

- Proprietary features in GroundWork Monitor include configuration build scripts, reports, graphs and related documentation. GroundWork has contributed significant portions of proprietary property / software code into the open source community under the GPL 2.0 license, an open source license. This includes Monarch, Foundation, and Status Viewer. GroundWork does have other proprietary property / software code that are licensed under a commercial license according to the terms of Subscription Agreement ${ }^{160}$

2. Revenue source

- Software: Groundwork Monitor Small Business and Groundwork Monitor Professional are enhanced version of Groundwork Monitor Open Source ${ }^{161}$

\footnotetext{
${ }^{153} \mathrm{http://www.tmcnet.com/usubmit/2007/02/08/2324443.htm}$

${ }_{155} \mathrm{http}$ ://groundworkopensource.com/news/press releases/pr 052404 3million.html

$155 \mathrm{http://www.mayfield.com/newsarticles/groundwork033005.htm}$

${ }_{156} \mathrm{http}: / / \mathrm{www} . \mathrm{tmcnet.com} / \mathrm{usubmit} / 2007 / 02 / 08 / 2324443 \mathrm{htm}$

157 http://www.groundworkopensource.com/news/pr/20070123-momentum.html

${ }_{158} \mathrm{http}$ //www.groundworkopensource.com/customers/

159 http://www.technewsworld.com/story/55262.html

$160 \mathrm{http}: / /$ groundworkopensource.com/products/pro-licensefaq.html

$161 \mathrm{http}: / / \mathrm{www}$.groundworkopensource.com/products/
} 
- Training: 3-day long network monitoring course is provided ${ }^{162}$

3. Ecosystem

- In a few short months, the GroundWork community has grown to over two thousand members strong. Created Open Source Council and it includes founders of Cacti, Dojo, Ganglia, MRTG, NeDi, RRDTool, Sendpage and SmokePing. GroundWork Monitor Open Source is licensed under GPL Version $2^{163,164,165}$

4. Benefits and risks

Save customers 20 percent over the cost of commercial software.

GroundWork unifies leading open source projects to deliver enterprise-class

IT systems and network management solutions at a fraction of the cost of proprietary solutions $^{166,167}$

5. Relationship between open source project and commercial offering

- GroundWork Monitor Open Source provides a complete entry-level systems and network availability monitoring solution ${ }^{168}$. As the previous version of the suite, GroundWork said it would be available as a free-todownload open source version and as a subscription license Professional Version that includes updates and support capabilities ${ }^{169}$

\footnotetext{
${ }^{162} \mathrm{http}: / /$ groundworkopensource.com/training/sysmgr.html

$163 \mathrm{http} / / \mathrm{www} . g r o u n d w o r k o p e n s o u r c e . c o m / n e w s / \mathrm{pr} / 20070123$-momentum.html

${ }_{164} \mathrm{http}: / /$ en.wikipedia.org/wiki/GroundWork Monitor Open Source

$165 \mathrm{http} / /$ www.groundworkopensource.com/news/pr/20060815-council.html

$166 \mathrm{http}: / / \mathrm{www} . \mathrm{tmonet.com} / \mathrm{usubmit} / 2007 / 02 / 08 / 2324443 . \mathrm{htm}$

167 http://www.desktoplinux.com/news/NS5815688602.html

$168 \mathrm{http}: / /$ groundworkopensource.com/products/os-overview.html

${ }^{169}$ http://www.itweek.co.uk/itweek/news/2174736/groundwork-ships-open-source
} 
- GroundWork has developed a highly optimized design approach, which is captured in our proprietary GroundWork Design and Coverage Specification ${ }^{170}$

\section{B.9 Tenable Network Security}

1. Company

- In 2002, Renaud, the creator of Nessus OSS project, co-founded Tenable Network Security with Ron Gula, creator of the Dragon Intrusion Detection System and Jack Huffard. Tenable Network Security is the owner, sole developer and licensor for the Nessus source code, the Nessus trademark and the nessus.org domain worldwide. Tenable is privately held and located in Columbia, MD ${ }^{171}$

- The company was granted $\$ 100,000$ from Maryland Department of Business and Economic Development's venture capital fund.

- Tenable has $100 \%$ year over year revenue growth, and it has multiple Global 2000 customers in the US, Canada, Asia Pacific, and Europe. Over 200 enterprise and government customers worldwide ${ }^{172}$. Nessus has been used at an estimated 85,000 organizations ${ }^{173}$

2. Revenue source

\footnotetext{
${ }^{170} \mathrm{http}: / /$ www.groundworkopensource.com/about/approach.html

${ }^{171}$ http://www.nessus.org/about/

$172 \mathrm{http}: / / w w w$. infosecurityproductsguide.com/hot2006/TenableNetworkSecurity.html

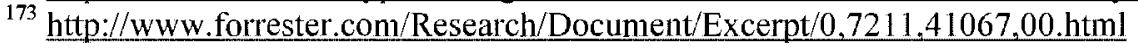


- Software packages. Nessus vulnerability scanner is an enhancement to Nessus OSS ${ }^{174}$. Security center and Log Correlation Engine are offered as well $^{175}$

- Service. Nessus Direct Feed is provided at $\$ 1200 /$ year/scanner ${ }^{176}$

- Product training and certification: $\$ 1,195 /$ student/training

3. Ecosystem

- Commercial product partners include Enterasys Networks, Reconnex ${ }^{177,178}$

- The OSS community it maintains is Nessus OSS project

4. Benefits and risks

- Overwhelming reason was to have a better relationship with our user base - a majority of which can't really use GPL code If it's not open source ${ }^{179}$, a lot of government agencies and enterprises can use it, where before they wouldn't

- There are many security product companies whose business model simply consists of putting Nessus on an appliance, writing a Web interface for it, and renaming it as their own solution. The popular vulnerability scanner reportedly is used in many commercial security products and services, such as ArcSight ${ }^{180}$, StillSecure, VeriSign, IBM Global Services,

\footnotetext{
${ }^{174}$ http://www.tenablesecurity.com/products/nessus.shtml

$175 \mathrm{http://www.tenablesecurity.com/products/index.shtml}$

$176 \mathrm{http://www.tenablesecurity.com/products/direct.shtml}$

177 http://www.tenablesecurity.com/news/pr64.shtml

$178 \mathrm{http://www.reconnex.net/news} \mathrm{events/pr/pr} \mathrm{07.24.06.php}$

$179 \mathrm{http}: / /$ www.security focus.com/columnists/371

180 http://www.networkworld.com/news/2005/101305-nessus.html
} 
Counterpane Internet Security, Symantec, AcuNett, ScannerX and rackAID $^{181}$

- OpenVAS (previously GNessUs) is a fork of the Nessus security scanner to ensure continued development of the project as free and open source. Porz-Wahn is another fork of Nessus. The forks are based on the Nessus 2.2.5 packages from GNU. The OpenVAS is released under GPL Ver2, and Porz-Wahn is released under GPL ${ }^{182,183,184}$

5. Relationship between open source project and commercial offering

- Paid users get immediate update, and OSS get updates seven days later for free ${ }^{185}$

- From version 3.0, it's free but closed-source ${ }^{186,187}$. Although Nessus 3 is not released under the GPL, Tenable is still actively maintaining Nessus 2. We just released an update for Nessus 2.2 with lots of improvements ${ }^{188}$

- Tenable's founder, Renaud Deraison, continues to maintain Nessus along with Tenable's research and development staff. The majority of the new vulnerability checks are researched, written and tested by Tenable Network Security. The Nessus 2 scanner engine is $100 \%$ GPL, but makes extensive use of Tenable copywritten vulnerability checks ${ }^{189}$

\footnotetext{
${ }^{181} \mathrm{http}: / /$ searchsecurity.techtarget.com/originalContent/0,289142,sid14_gci1034903,00.html

$182 \mathrm{http://directory.fsf.org/all/openvas.html}$

183 http://porz-wahn.berlios.de/homepage/about.php

184 http://en.wikipedia.org/wiki/Nessus (software)

185 http://www.gen.com/online/voll nol/34810-1.html?topic=security

186 http://blogs.zdnet.com/open-source/?p=465

187 http://www.securityfocus.com/cgi-

bin/index.cgi?c=columncomments \&op=display comments\&ColumnID $=371 \&$ expand all =true\&mode $=$ thre aded

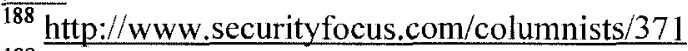

189 http://www.tenablesecurity.com/products/nessus tenable.shtml
} 


\section{B.10 Vyatta}

1. Company

- Founded in 2005, the company launched its first router product in 2006.

The company's product OFR runs on commodity PC ${ }^{190}$

- The company received $\$ 7.5 \mathrm{~m}$ VC investment from JP Morgan Partners, ComVentrures, Arrow Path Venture Partners in September $2006^{191}$. And it raised $\$ 11 \mathrm{~m}$ from Comcast Interactive Capital and all existing investors in April $2007^{192}$

- The company has 20 employees as of July $2006^{193}$

2. Revenue source ${ }^{194}$

- Appliance: the software is pre-installed onto a Dell PC ${ }^{195,} 196$

- Software and subscription: customer can buy different level of support

(Vyatta Software Enterprise Subscription, Vyatta Software Professional Services) $)^{197}$

- Service: Remote Consulting Service is offered ${ }^{198}$

3. Ecosystem

- The company depends on the community to generate ideas what to put into its product ${ }^{199}$

\section{Benefits and risks}

\footnotetext{
${ }^{190} \mathrm{http}: / / \mathrm{www}$. indiabandwidth.com/broadband wireline/broadbandwirelinenews $20 . \mathrm{html}$

191 http://www. lightreading.com/document.asp?doc id $=103684$

192 http://www.vyatta.com/about/pressreleases.php?id=32

193 http://www.indiabandwidth.com/broadband wireline/broadbandwirelinenews $20 . h t m l$

194 http://www.vyatta.com/products/plans.php

$195 \mathrm{http}: / \mathrm{www} 2 . v y a t t a . c o m /$ store/Hardware-Appliances-with-Enterprise-Subscriptions

$196 \mathrm{http} / /$ www2.vyatta.com/store/Appliances-with-Professional-Subscriptions

$197 \mathrm{http}: / / \mathrm{www} 2 . \mathrm{vyatta.com} /$ support/Support-Offerings

$198 \mathrm{http}: / /$ www2.vyatta.com/store/Professional-Services

199 http://www.computerworld.com.au/index.php/id:141322315;pp;2;fp;4194304;fpid;1
} 
- Cheap cost. Including the subscription cost, the cost of running a Vyatta router is about one-third that of running an equivalent Cisco product ${ }^{200}$

- Increased flexibility and choices, and better security. The company's email list provides good support to its customers by its stuff or another user $^{201}$

- Fast time to market and reliable product. It stands on the shoulders of giants (i.e. Linux, and XORP), and it does not have to reinvent the wheels ${ }^{202}$

- The customers only include early adopters. Many major companies saying they get the idea, but they are not sure it their organization is ready for $\mathrm{it}^{203}$

5. Relationship between open source project and commercial offering

- The OSS get patches and bug fixes every 6 months, paid customers get all patches and bug fixes immediately ${ }^{204}$

\footnotetext{
${ }^{200} \mathrm{http} / / /$ news.zdnet.co.uk/software/0,1000000121,39285946,00.htm

$201 \mathrm{http}$ //angrytelecomgeek.blogspot.com/2007/02/vyatta-ofr-review.html

${ }^{202}$ http://www.computerworld.com.au/index.php/id;141322315;fp;4194304;fpid;1

${ }^{203} \mathrm{http://www.computerworld.com.au/index.php/id;141322315;pp;2:fp;4194304:fpid;1}$

${ }^{204}$ http://www.vyatta.com/products/index.php
} 


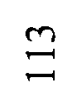

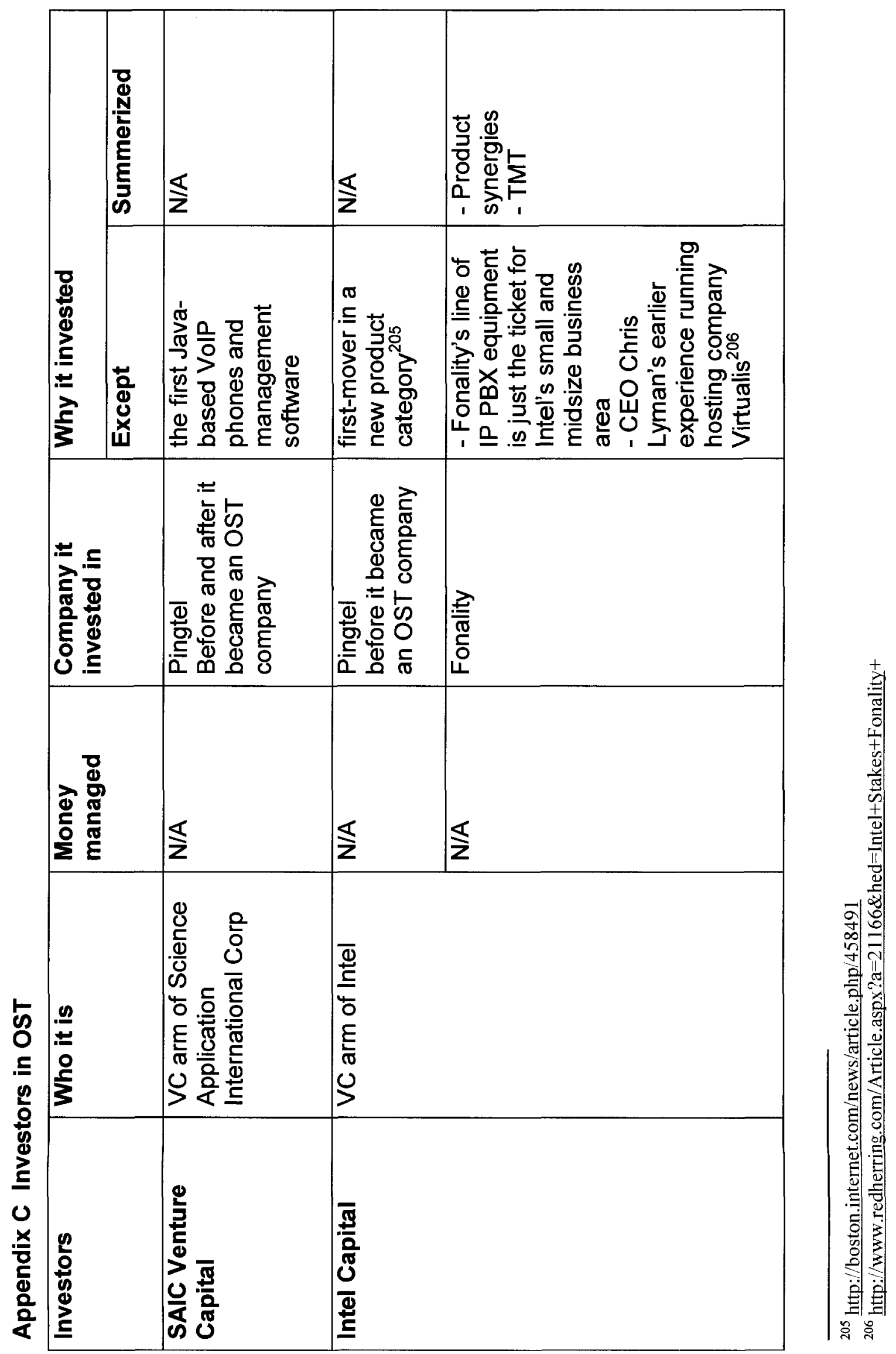



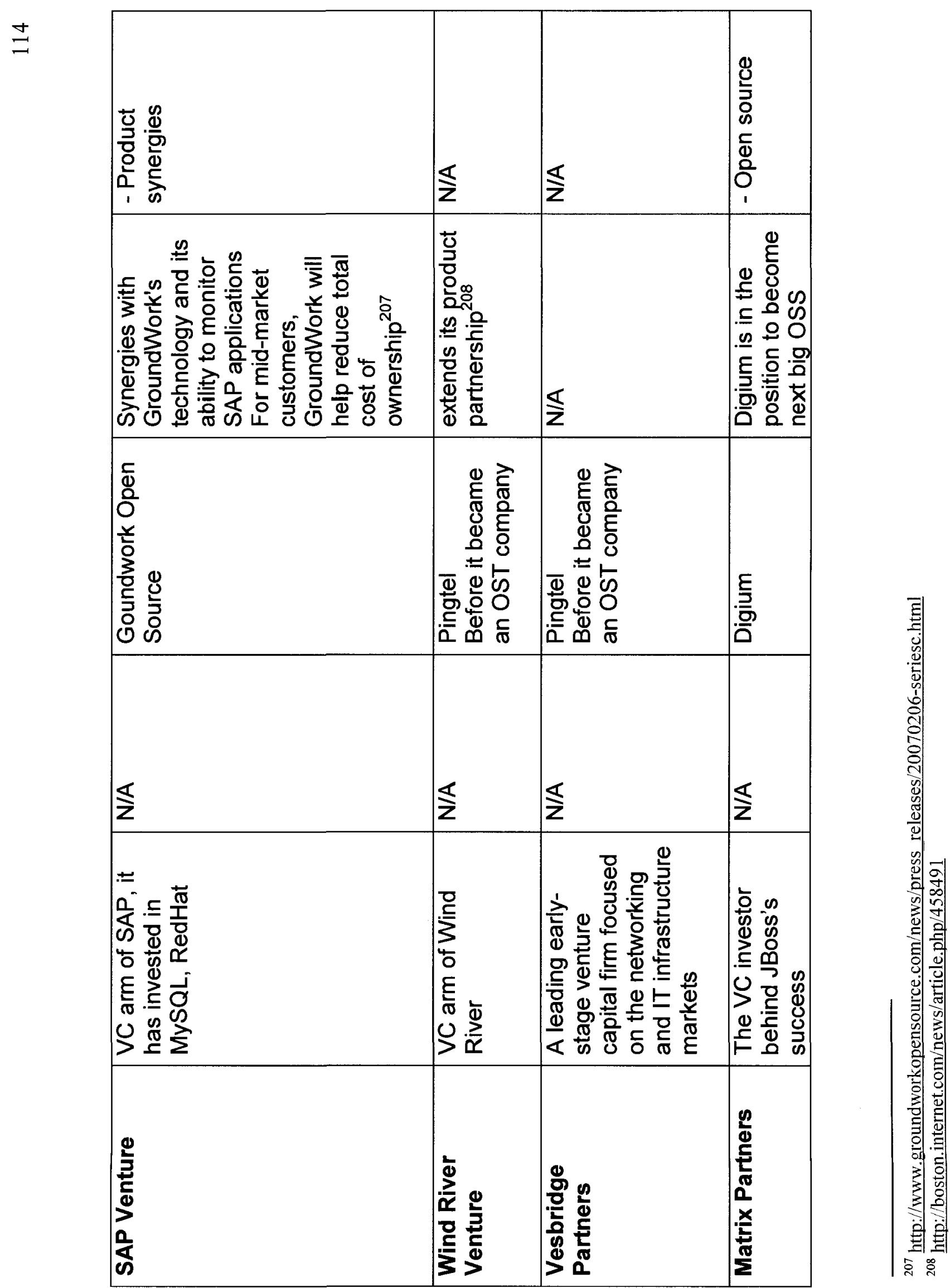
$\cong$

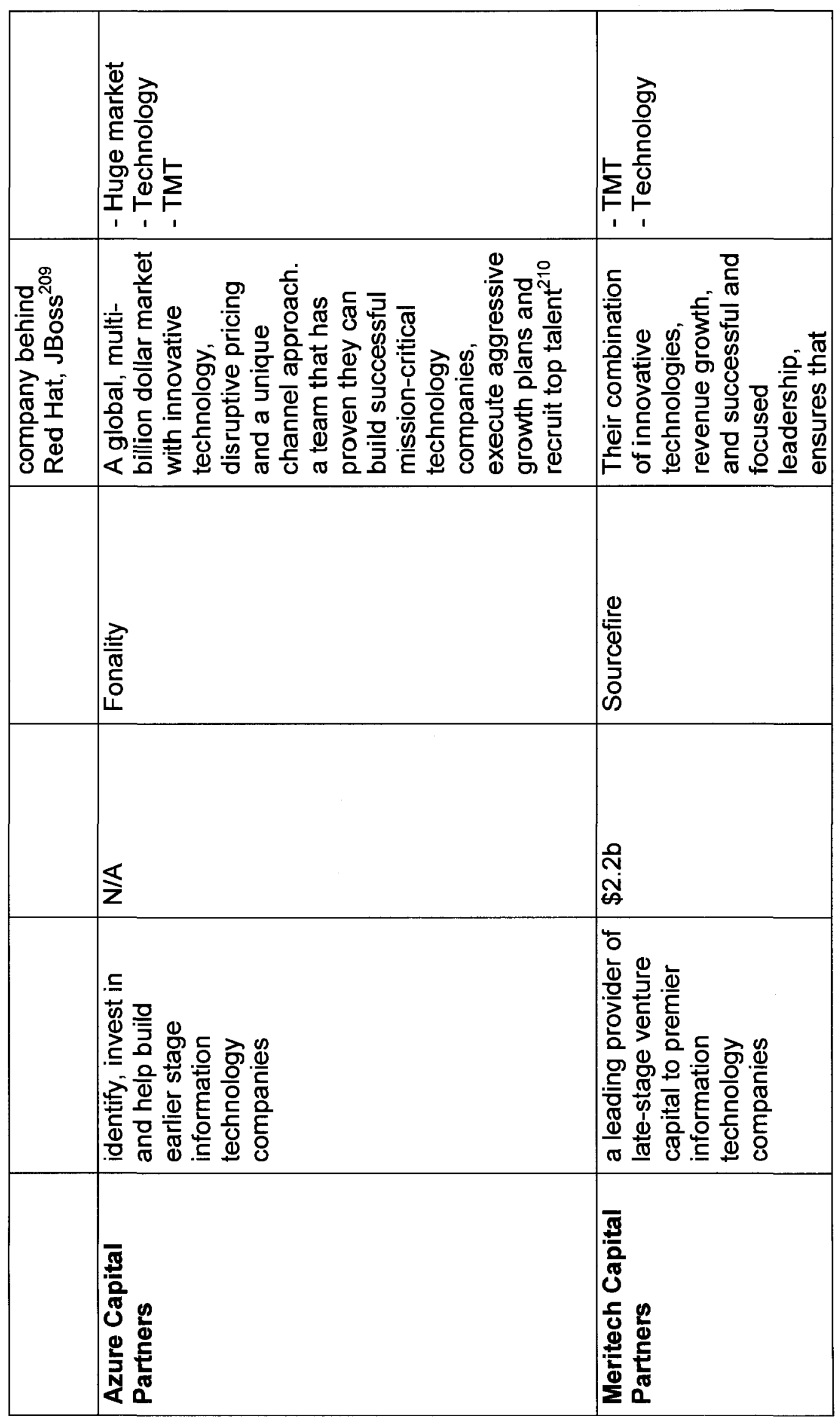



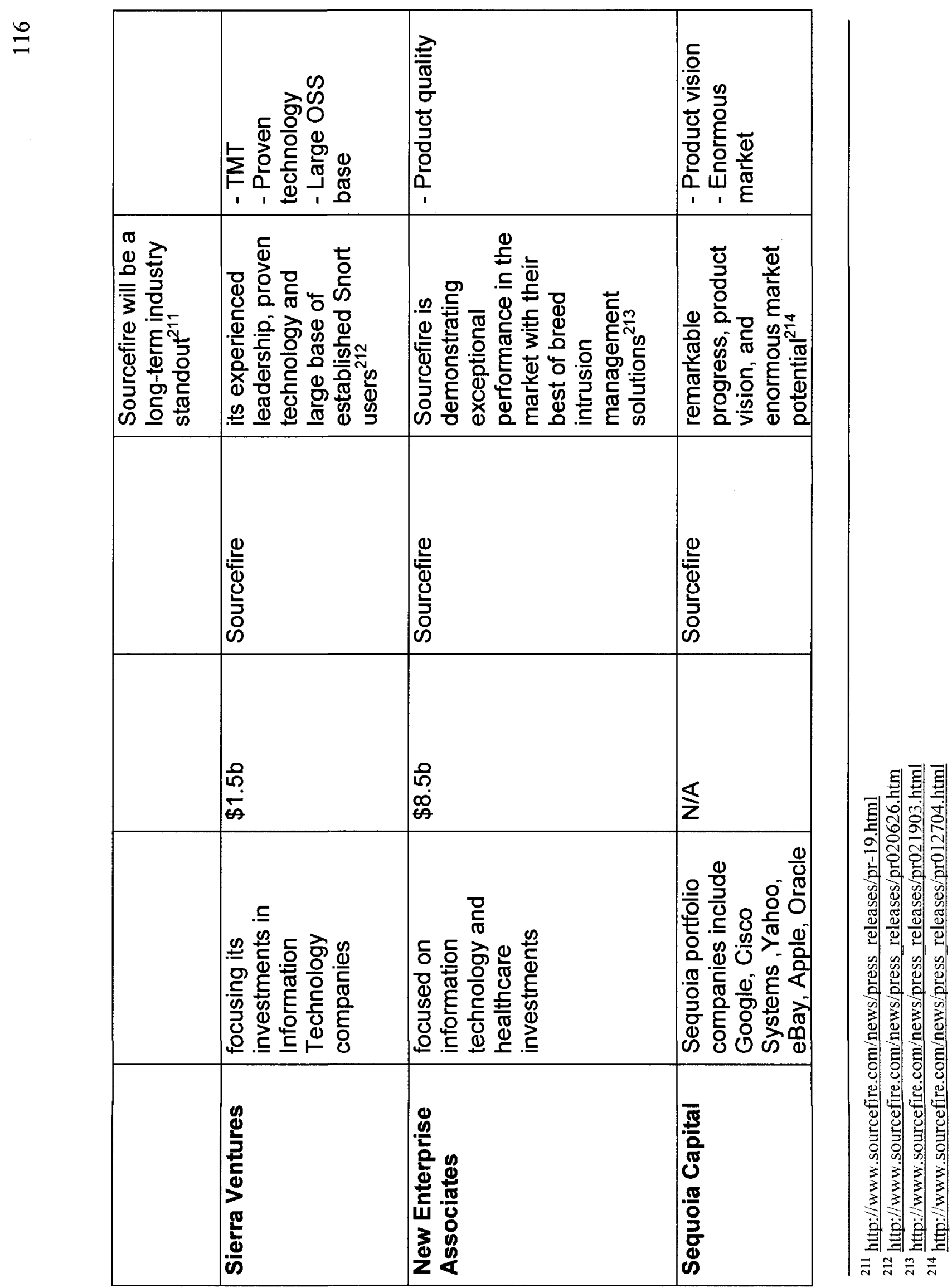

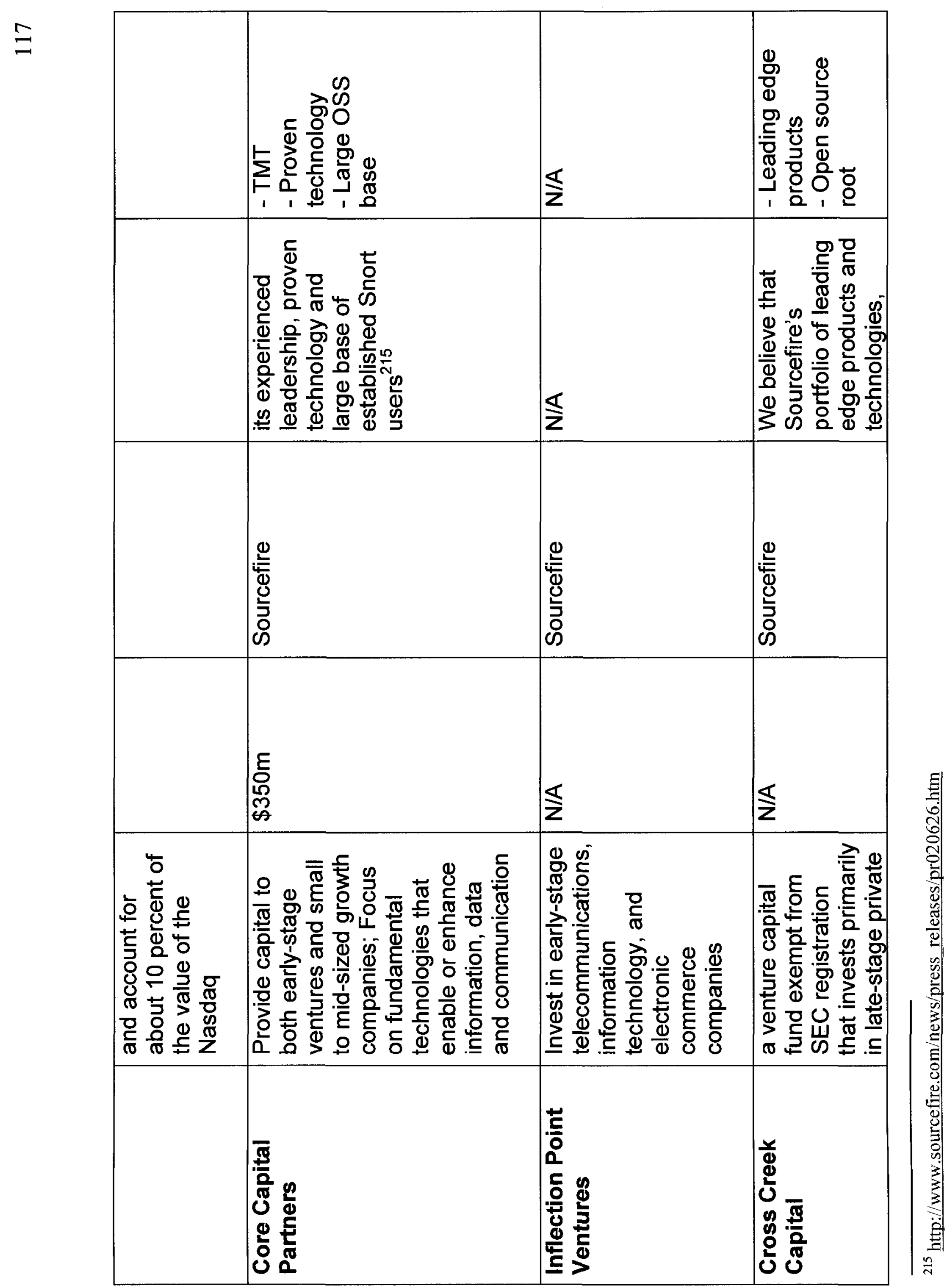

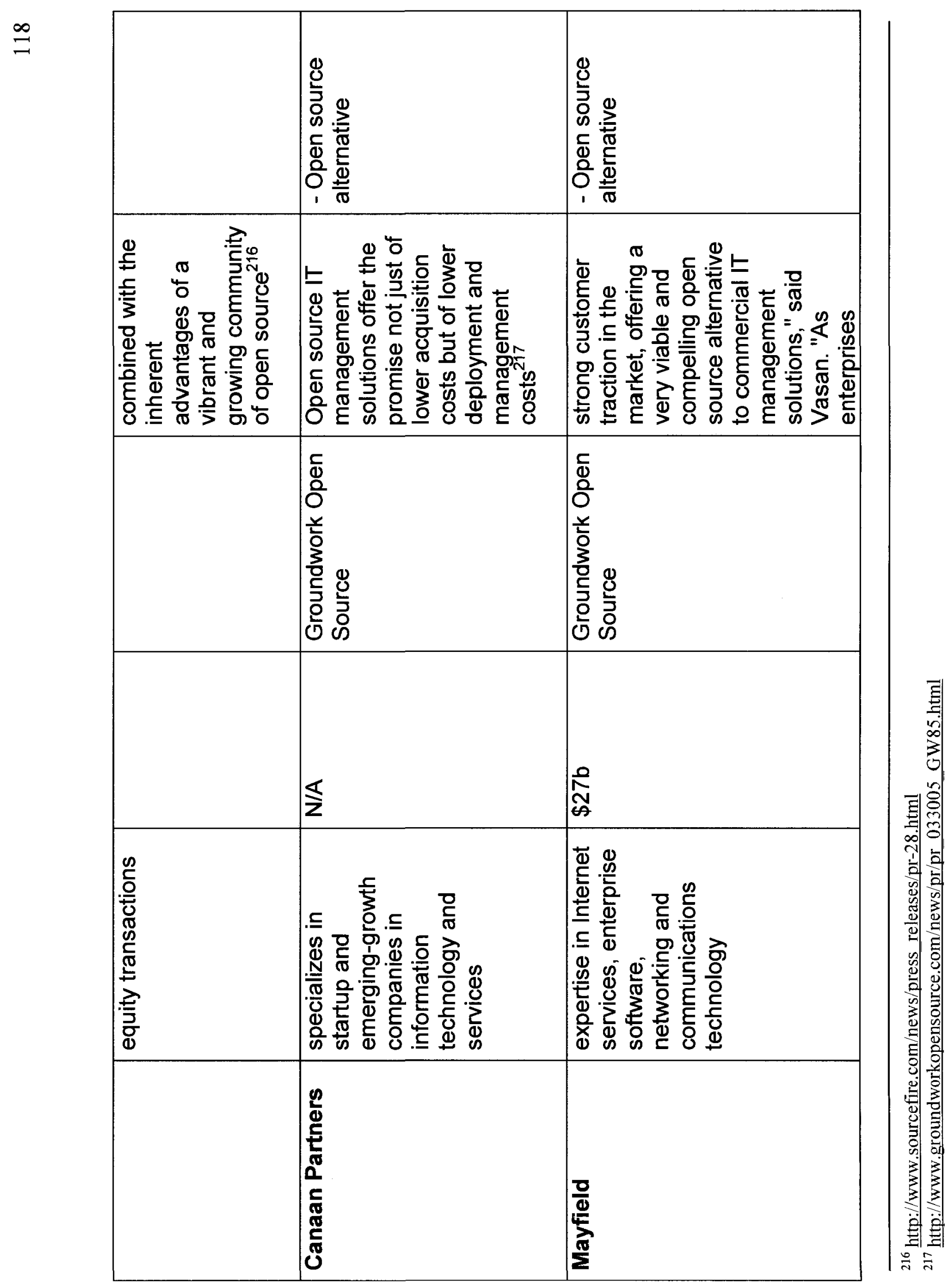


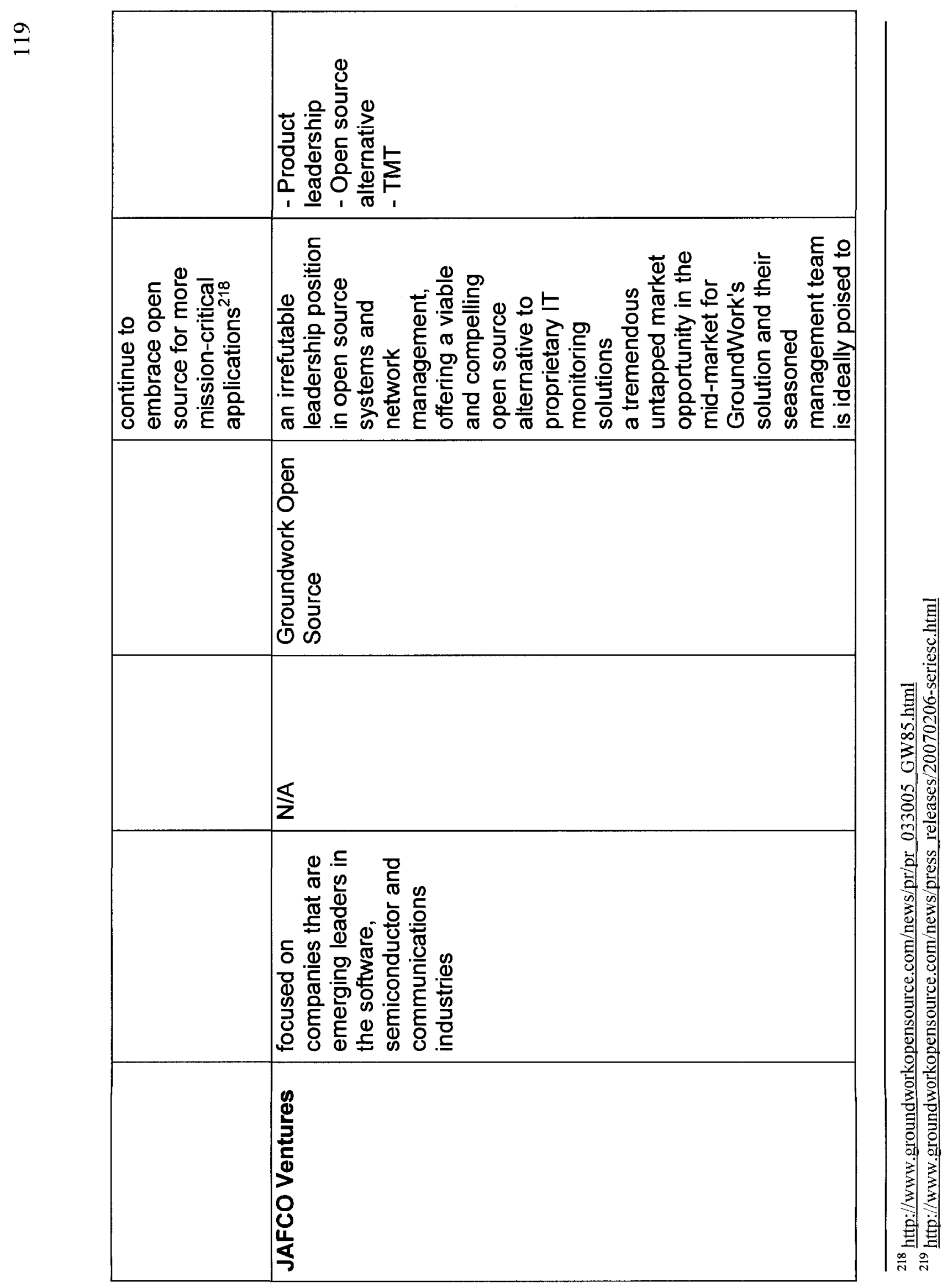


ㄱ

\begin{tabular}{|c|c|c|c|c|}
\hline & $\frac{\Sigma}{z}$ & $\frac{\mathbf{s}}{\mathbf{z}}$ & $\frac{\delta}{\mathbf{z}}$ & 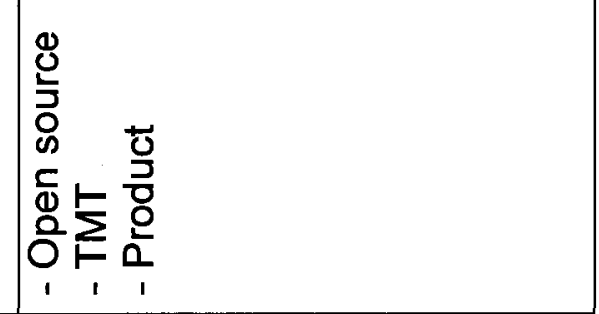 \\
\hline 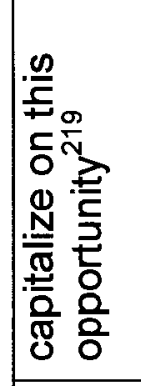 & $\frac{\Sigma}{\mathbf{z}}$ & $\frac{\Sigma}{2}$ & $\underline{\mathbf{s}}$ & 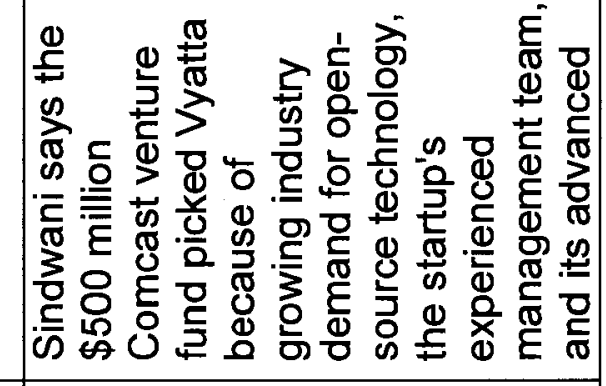 \\
\hline & 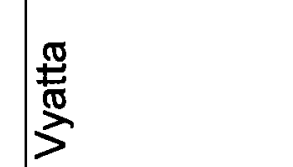 & $\begin{array}{l}\text { 要 } \\
\text { 焉 }\end{array}$ & $\begin{array}{l}\frac{\mathrm{w}}{\mathrm{w}} \\
\frac{\mathrm{W}}{3}\end{array}$ & $\begin{array}{l}\frac{5}{5} \\
\frac{5}{5} \\
3\end{array}$ \\
\hline & $\frac{\Sigma}{z}$ & $\frac{\mathbb{s}}{\mathbf{z}}$ & 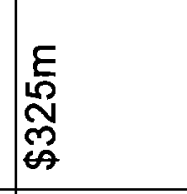 & 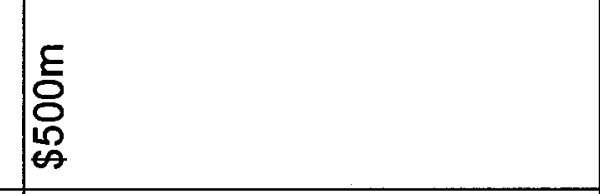 \\
\hline & 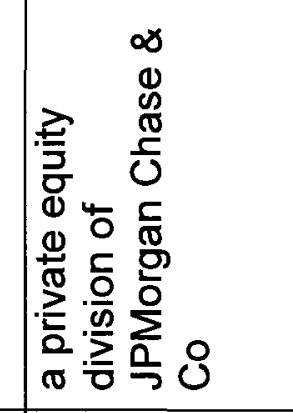 & 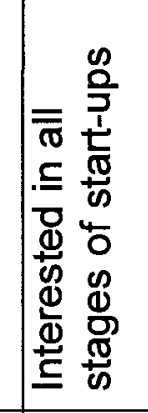 & 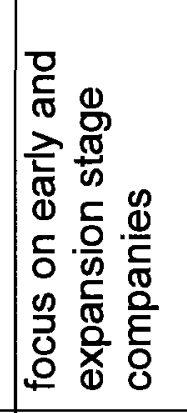 & 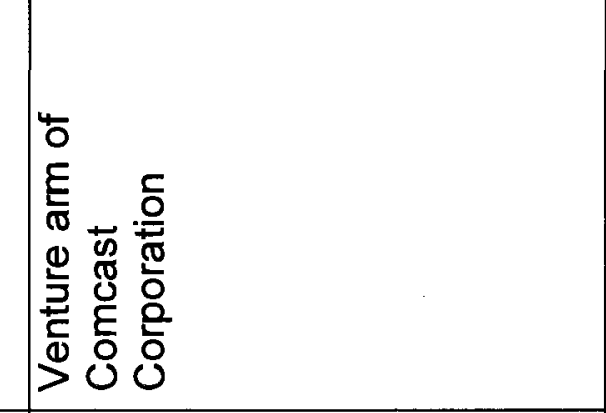 \\
\hline & 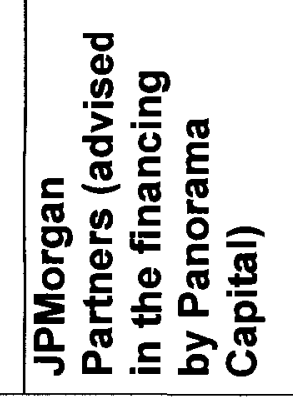 & 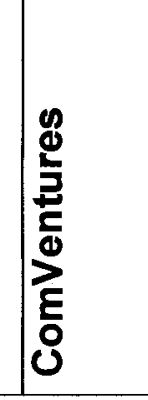 & 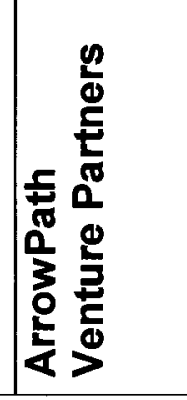 & 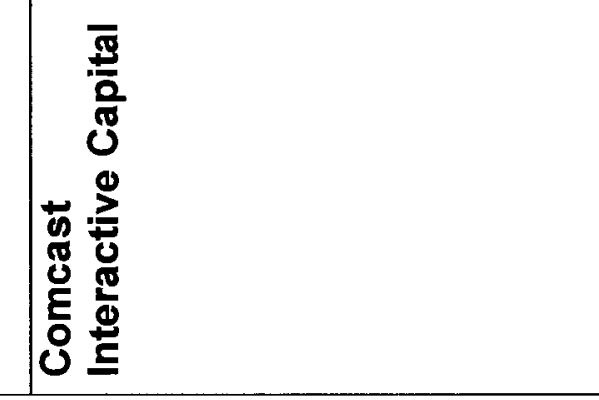 \\
\hline
\end{tabular}



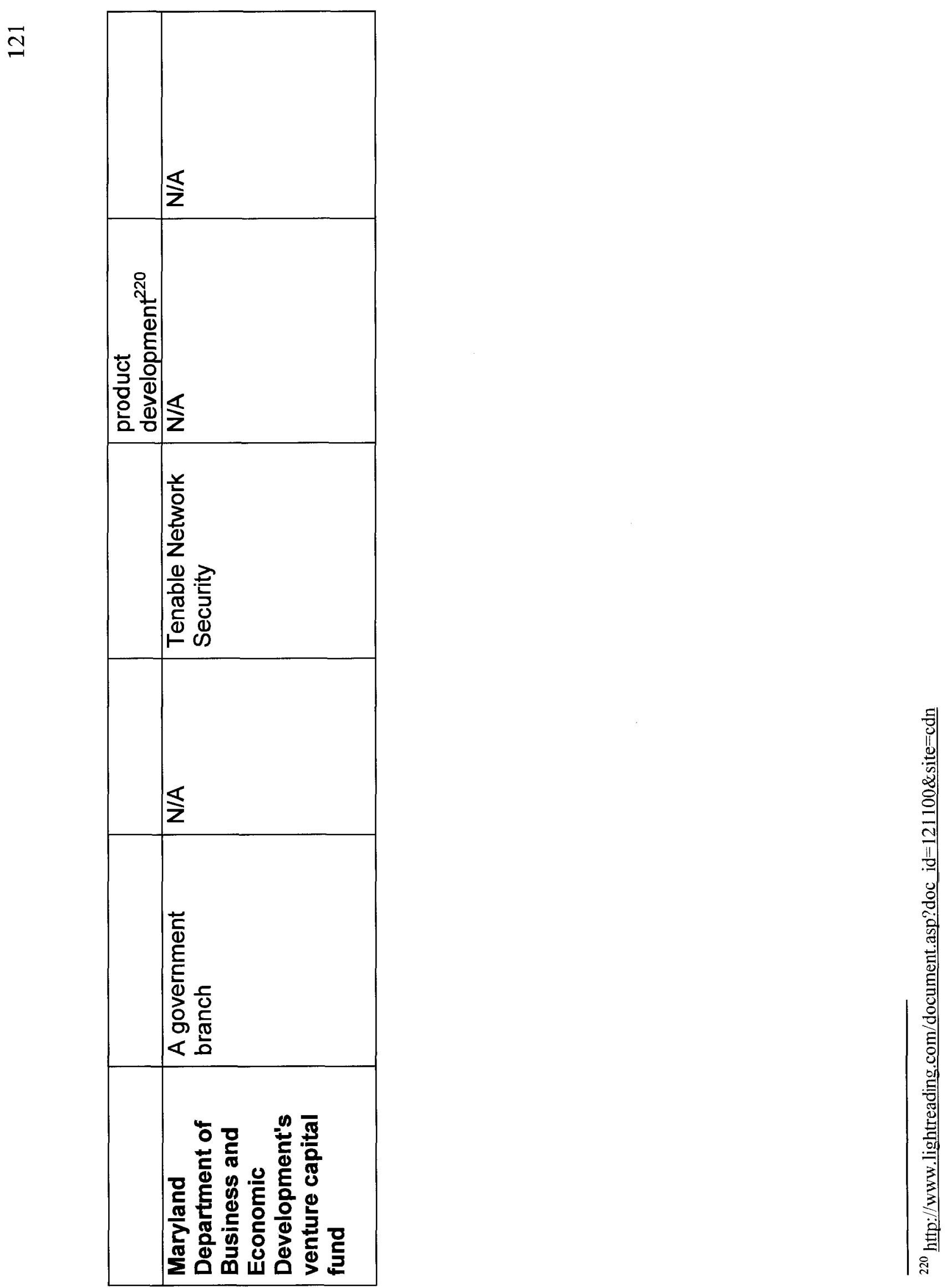
ป

\begin{tabular}{|c|c|c|c|c|c|}
\hline & & 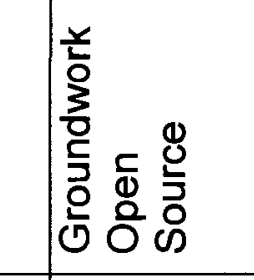 & $\frac{\vec{a}}{9}$ & 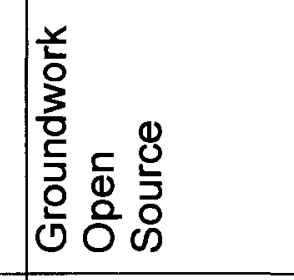 & 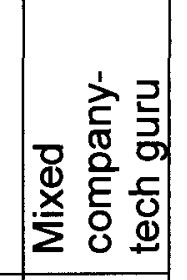 \\
\hline 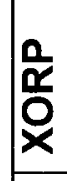 & ¿े & 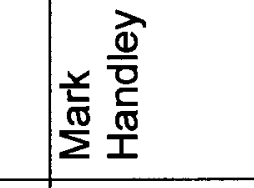 & 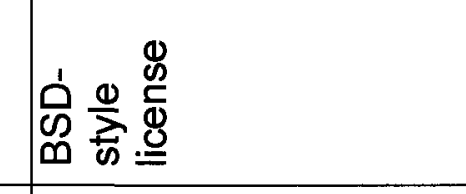 & $\begin{array}{l}\frac{1}{5} \\
\text { 焉 }\end{array}$ & 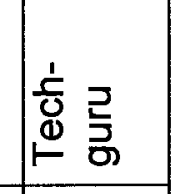 \\
\hline 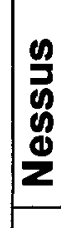 & $\mid \begin{array}{l}\infty \\
\stackrel{\infty}{\sigma} \\
\stackrel{2}{\sigma}\end{array}$ & 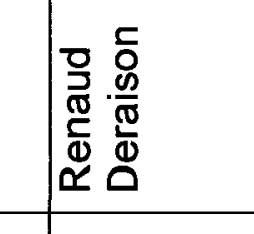 & 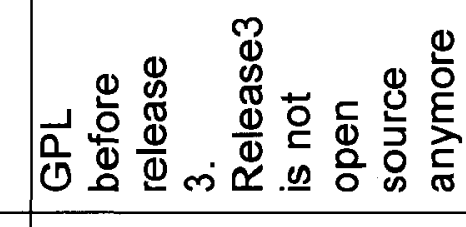 & 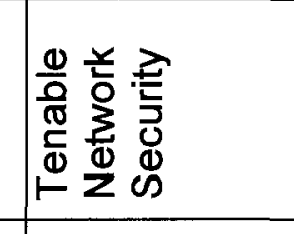 & 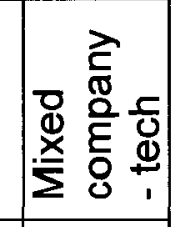 \\
\hline 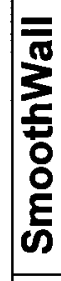 & वे & 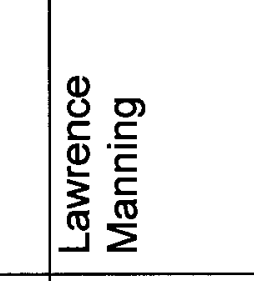 & $\frac{\vec{a}}{0}$ & 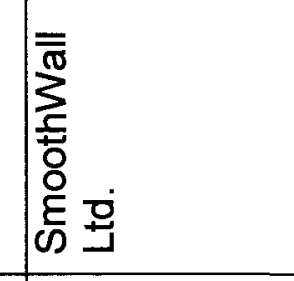 & 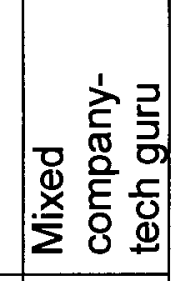 \\
\hline$\frac{\mathscr{n}}{9}$ & g: & 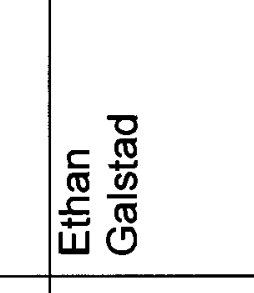 & $\mid \begin{array}{l}\vec{a} \\
\underline{a}\end{array}$ & 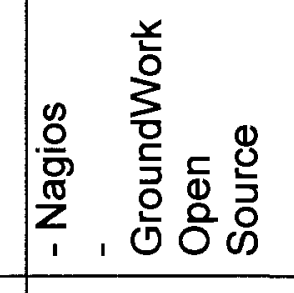 & 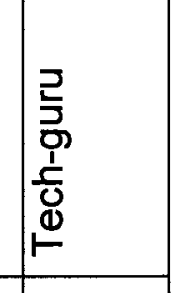 \\
\hline 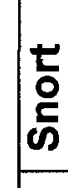 & $\begin{array}{l}\infty \\
\text { : } \\
\end{array}$ & 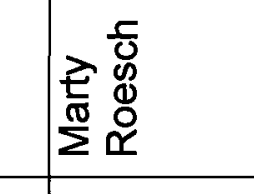 & $\vec{a}$ & 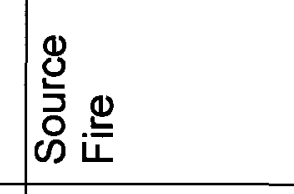 & 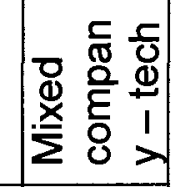 \\
\hline & $\begin{array}{l}\text { ठ̀े } \\
\text { 亏ે }\end{array}$ & 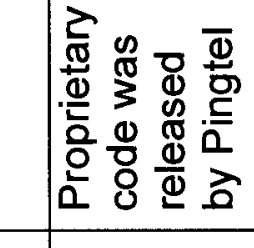 & 离 & 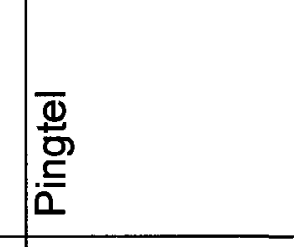 & 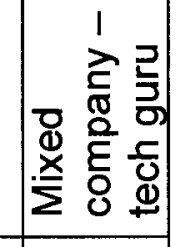 \\
\hline & 惖 & 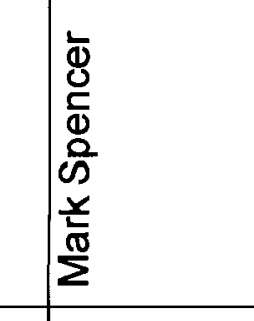 & 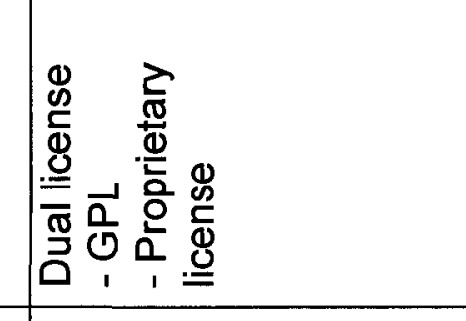 & 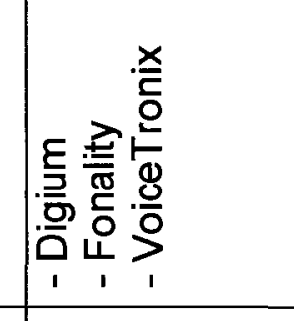 & 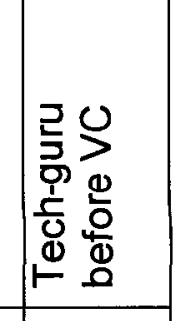 \\
\hline & & 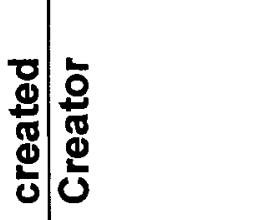 & 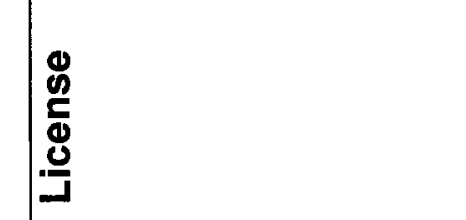 & 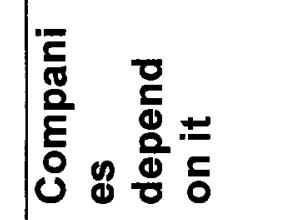 & 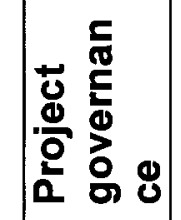 \\
\hline
\end{tabular}


I

\begin{tabular}{|c|c|c|c|}
\hline & 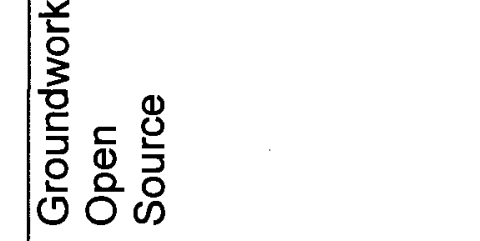 & $\mid$ & $\frac{\mathbb{s}}{z}$ \\
\hline & 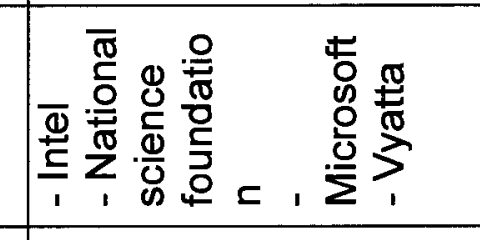 & \begin{tabular}{|l}
5 \\
$\frac{1}{0}$ \\
$\frac{0}{2}$ \\
5 \\
5
\end{tabular} & $\frac{\mathbb{s}}{\mathbf{z}}$ \\
\hline 름 & 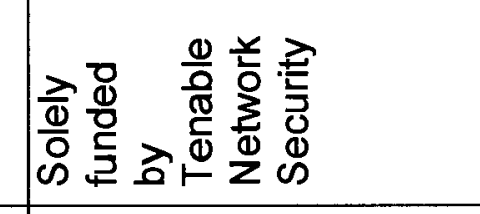 & 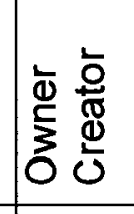 & 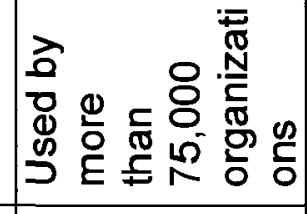 \\
\hline & 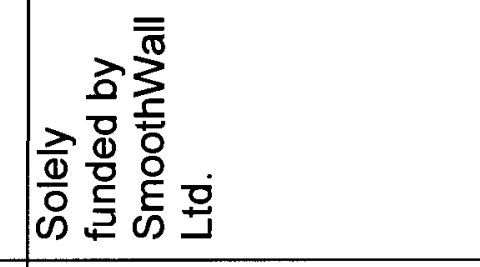 & 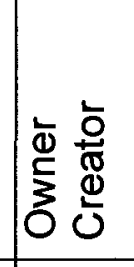 & $\mid$\begin{tabular}{|}
+ \\
$\underline{E}$
\end{tabular} \\
\hline & 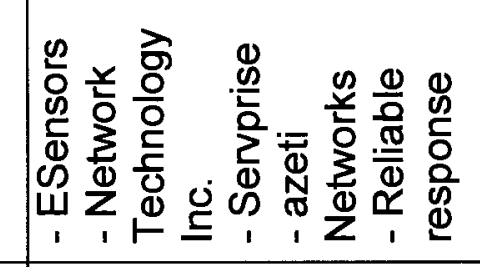 & 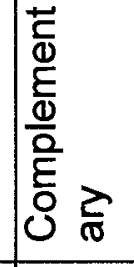 & $\frac{\mathbb{z}}{\mathbf{z}}$ \\
\hline 롱 & $\mid$ & 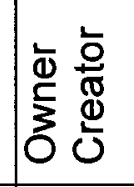 & 莺 \\
\hline & 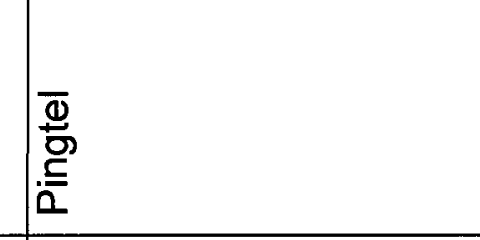 & 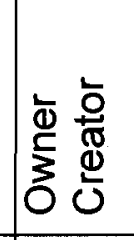 & | \\
\hline 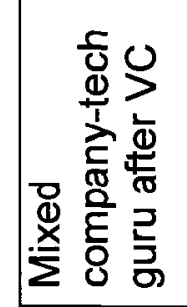 & $\mid$\begin{tabular}{l}
$\overline{5}$ \\
\hdashline \\
$\overline{0}$
\end{tabular} & 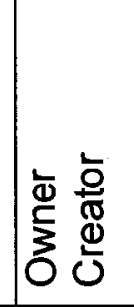 & 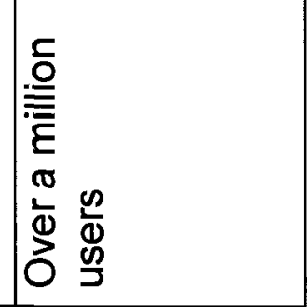 \\
\hline & \begin{tabular}{|l}
2 \\
0 \\
0 \\
0 \\
0 \\
0 \\
0 \\
0
\end{tabular} & 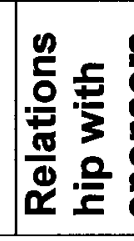 & 焉 \\
\hline
\end{tabular}

